Prepared in cooperation with the Bureau of Reclamation

\title{
Simulation of Groundwater-Level Changes from Projected Groundwater Withdrawals in the Truxton Basin, Northwestern Arizona
}

Chapter E of

Geophysical Surveys, Hydrogeologic Characterization, and Groundwater Flow Model for the Truxton Basin and Hualapai Plateau, Northwestern Arizona

Scientific Investigations Report 2020-5017-E

U.S. Department of the Interior U.S. Geological Survey 
Cover. Oblique aerial view looking west at western end of the Truxton basin and hydrologic outlet through Truxton Canyon. Rugged area left of Truxton Canyon are the Cottonwood Mountains. Rugged area to the right of the canyon are the Music Mountains. Photo by Jon Mason, U.S. Geological Survey, September 2015.

Cover inset. Three-dimensional perspective of the Truxton Basin Hydrologic Model viewing the Truxton basin and surrounding area from the south. 


\section{Simulation of Groundwater-Level Changes from Projected Groundwater Withdrawals in the Truxton Basin, Northwestern Arizona}

By Jacob E. Knight

Chapter E of

Geophysical Surveys, Hydrogeologic Characterization, and Groundwater Flow Model for the Truxton Basin and Hualapai Plateau, Northwestern Arizona

Edited by Jon P. Mason

Prepared in cooperation with the Bureau of Reclamation

Scientific Investigations Report 2020-5017-E 


\title{
U.S. Department of the Interior DAVID BERNHARDT, Secretary
}

\author{
U.S. Geological Survey \\ James F. Reilly II, Director
}

\section{U.S. Geological Survey, Reston, Virginia: 2020}

For more information on the USGS - the Federal source for science about the Earth, its natural and living resources, natural hazards, and the environment-visit https://www.usgs.gov or call 1-888-ASK-USGS (1-888-275-8747).

For an overview of USGS information products, including maps, imagery, and publications, visit https://store.usgs.gov.

Any use of trade, firm, or product names is for descriptive purposes only and does not imply endorsement by the U.S. Government.

Although this information product, for the most part, is in the public domain, it also may contain copyrighted materials as noted in the text. Permission to reproduce copyrighted items must be secured from the copyright owner.

Suggested citation:

Knight, J.E., 2020, Simulation of groundwater-level changes from projected groundwater withdrawals in the Truxton basin, northwestern Arizona, chap. E of Mason, J.P., ed., Geophysical surveys, hydrogeologic characterization, and groundwater flow model for the Truxton basin and Hualapai Plateau, northwestern Arizona: U.S. Geological Survey Scientific Investigations Report 2020-5017, 39 p., https://doi.org/10.3133/sir20205017E.

Associated data for this publication:

Knight, J.E., 2020, Data release for transient groundwater model of the Truxton aquifer on the Hualapai Reservation and adjacent areas, Mohave County, Arizona: U.S. Geological Survey data release, https://doi.org/10.5066/P902WGLS.

ISSN 2328-0328 (online) 


\section{Acknowledgments}

Thanks to Peter Huntoon for sharing his time and expertise of the study area. Thanks also to Fred D. Tillman for assisting with the organization of this report and providing valuable feedback throughout the writing process.

\section{Contents}

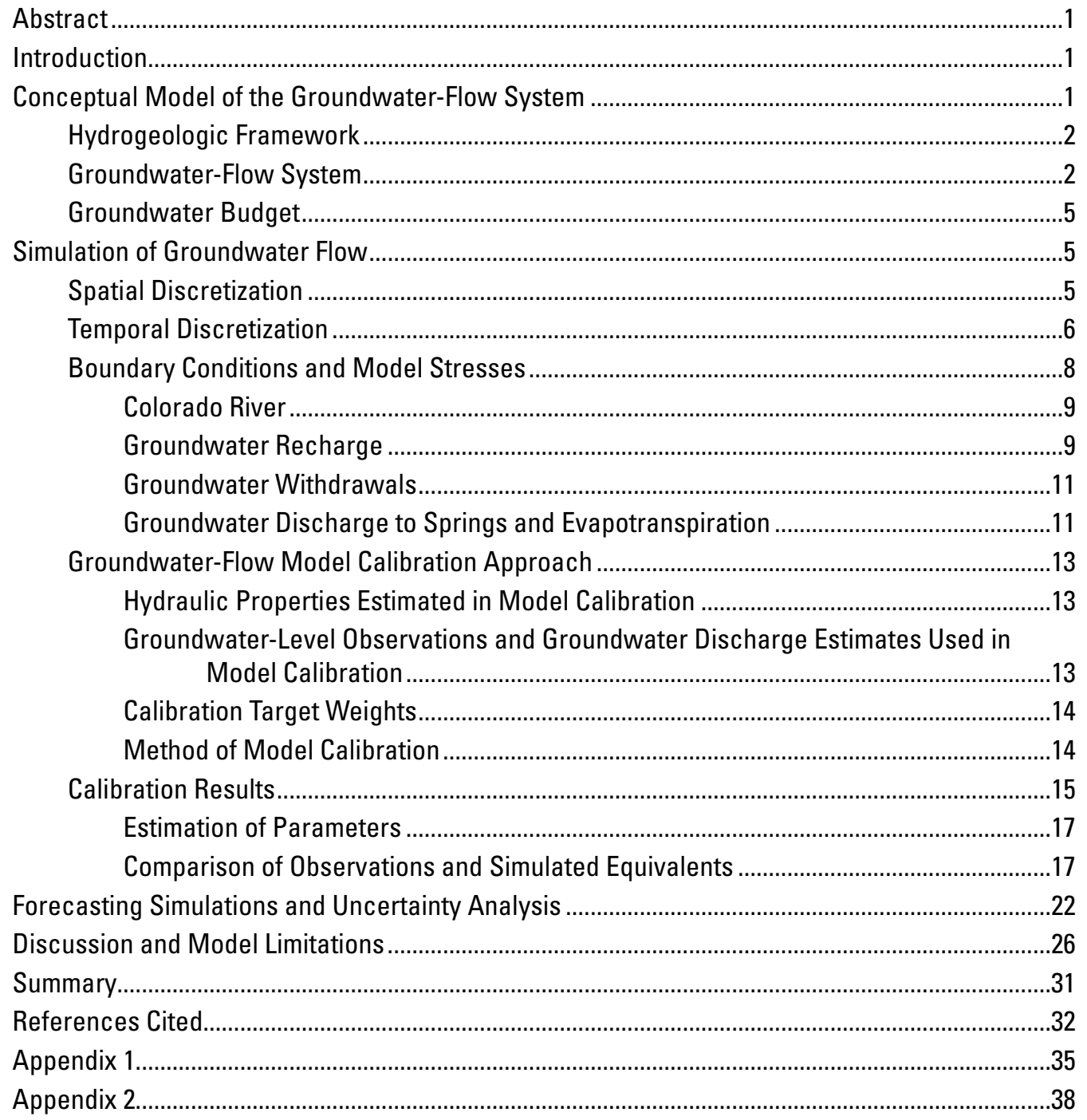




\section{Figures}

1. The Truxton basin groundwater-flow system boundaries .3

2. Conceptual model of the Truxton basin groundwater-flow system...

3. Truxton Basin Hydrologic Model aquifer-property zones by model layer...

4. Location of drain cells, constant-head cells, and groundwater withdrawals in the Truxton Basin Hydrologic Model.

5. Functions considered to convert spatially distributed rates of long-term average precipitation to recharge rates for the Truxton Basin Hydrologic Model

6. Modified Maxey-Eakin, precipitation-to-recharge conversion factors and the resulting recharge distribution

7. Well and spring locations and flux-observation zones simulated in the Truxton Basin Hydrologic Model.

8. Truxton Basin Hydrologic Model pilot-point distribution by aquifer-property zone for estimation of spatially distributed aquifer property parameters.

9. Calibrated horizontal hydraulic conductivity values in aquifer-property zones.

10. Horizontal hydraulic conductivity values by aquifer-property zone and flux-observation drain conductance values

11. The 40 highest composite-scaled sensitivities of automatically calibrated model parameters in the Truxton Basin Hydrologic Model ..........................................................2

12. Observed versus simulated heads, and observed heads versus simulated residuals.......20

13. Head target residuals from the calibrated Truxton Basin Hydrologic Model......................21

14. Estimated flux targets and simulated equivalents of total groundwater discharge by flux-observation zone ...................................................................................................22

15. Simulated groundwater discharge at head-dependent flux model cells ............................23

16. Truxton Basin Hydrologic Model simulated head contours and flow directions.................24

17. Truxton Basin Hydrologic Model forecasting simulation.....................................................25

18. Simulated drawdown at year 2070 and year 2140 from simulated year 2020 levels for low, medium, and high pumping scenarios using the primary bedrock altitude model.....25

19. Summary of groundwater-level change forecasted in Monte Carlo simulations using the primary bedrock altitude model for the low pumping scenario, medium pumping scenario, and high pumping scenario from 2020-2070 and 2020-2140 at select locations in Truxton basin.

20. Frequency of forecasted groundwater-level changes at select locations in the Truxton basin, 2020-2070 and 2020-2140, from Monte Carlo model ensembles that represent the low pumping scenario, medium pumping scenario, and high pumping scenario with primary, high, and low basin bedrock altitudes

21. Relation of multiplier parameters to simulated groundwater-level change from 2020-2070 and 2020-2140 


\section{Tables}

1. Estimated predevelopment groundwater-budget values for the western Hualapai Plateau, eastern Hualapai Plateau, and Truxton basin ....

2. Truxton Basin Hydrologic Model simulation stress periods..............................................6

3. Comparison of total recharge flux resulting from application of different precipitation/ recharge relations

4. Production wells simulated in the Truxton Basin Hydrologic Model....................................11

5. Initial hydraulic property parameter values for each aquifer-property zone of the Truxton Basin Hydrologic Model.

6. Lower- and upper-bounds for estimated hydraulic property parameter values within aquifer-property zones of the Truxton Basin Hydrologic Model

7. Estimated long-term average groundwater discharge by springs and evapotranspiration in each flux-observation zone of the Truxton Basin Hydrologic Model..

8. Initial value and range for adjustable aquifer property parameters in forecast Monte Carlo simulations.

9. Multiplying factors used in forecast Monte Carlo simulations.............................................27

10. Summary of failed, rejected, and accepted Monte Carlo model runs .................................27 


\section{Conversion Factors}

U.S. customary units to International System of Units

\begin{tabular}{|c|c|c|}
\hline Multiply & By & To obtain \\
\hline \multicolumn{3}{|c|}{ Length } \\
\hline inch (in.) & 2.54 & centimeter $(\mathrm{cm})$ \\
\hline inch (in.) & 25.4 & millimeter $(\mathrm{mm})$ \\
\hline foot $(\mathrm{ft})$ & 0.3048 & meter $(\mathrm{m})$ \\
\hline mile (mi) & 1.609 & kilometer $(\mathrm{km})$ \\
\hline \multicolumn{3}{|c|}{ Area } \\
\hline acre & 4,047 & square meter $\left(\mathrm{m}^{2}\right)$ \\
\hline acre & 0.4047 & hectare (ha) \\
\hline acre & 0.4047 & square hectometer $\left(\mathrm{hm}^{2}\right)$ \\
\hline acre & 0.004047 & square kilometer $\left(\mathrm{km}^{2}\right)$ \\
\hline square mile $\left(\mathrm{mi}^{2}\right)$ & 259.0 & hectare (ha) \\
\hline square mile $\left(\mathrm{mi}^{2}\right)$ & 2.590 & square kilometer $\left(\mathrm{km}^{2}\right)$ \\
\hline \multicolumn{3}{|c|}{ Volume } \\
\hline gallon (gal) & 3.785 & liter (L) \\
\hline gallon (gal) & 0.003785 & cubic meter $\left(\mathrm{m}^{3}\right)$ \\
\hline cubic foot $\left(\mathrm{ft}^{3}\right)$ & 0.02832 & cubic meter $\left(\mathrm{m}^{3}\right)$ \\
\hline cubic yard $\left(\mathrm{yd}^{3}\right)$ & 0.7646 & cubic meter $\left(\mathrm{m}^{3}\right)$ \\
\hline acre-foot (acre-ft) & 1,233 & cubic meter $\left(\mathrm{m}^{3}\right)$ \\
\hline acre-foot (acre-ft) & 0.001233 & cubic hectometer $\left(\mathrm{hm}^{3}\right)$ \\
\hline \multicolumn{3}{|c|}{ Flow rate } \\
\hline acre-foot per day (acre-ft/d) & 0.01427 & cubic meter per second $\left(\mathrm{m}^{3} / \mathrm{s}\right)$ \\
\hline acre-foot per year (acre-ft/yr) & 1,233 & cubic meter per year $\left(\mathrm{m}^{3} / \mathrm{yr}\right)$ \\
\hline foot per day $(\mathrm{ft} / \mathrm{d})$ & 0.3048 & meter per day $(\mathrm{m} / \mathrm{d})$ \\
\hline cubic foot per second $\left(\mathrm{ft}^{3} / \mathrm{s}\right)$ & 0.02832 & cubic meter per second $\left(\mathrm{m}^{3} / \mathrm{s}\right)$ \\
\hline gallon per minte (gal/min) & 0.06309 & liter per second $(\mathrm{L} / \mathrm{s})$ \\
\hline \multicolumn{3}{|c|}{ Hydraulic conductivity } \\
\hline foot per day (ft/d) & 0.3048 & meter per day $(\mathrm{m} / \mathrm{d})$ \\
\hline \multicolumn{3}{|c|}{ Hydraulic gradient } \\
\hline foot per mile (ft/mi) & 0.1894 & meter per kilometer $(\mathrm{m} / \mathrm{km})$ \\
\hline \multicolumn{3}{|c|}{ Transmissivity } \\
\hline foot squared per day $\left(\mathrm{ft}^{2} / \mathrm{d}\right)$ & 0.09290 & meter squared per day $\left(\mathrm{m}^{2} / \mathrm{d}\right)$ \\
\hline
\end{tabular}


International System of Units to U.S. customary units

\begin{tabular}{|c|c|c|}
\hline Multiply & By & To obtain \\
\hline \multicolumn{3}{|c|}{ Length } \\
\hline meter $(\mathrm{m})$ & 3.281 & foot $(\mathrm{ft})$ \\
\hline kilometer $(\mathrm{km})$ & 0.6214 & mile (mi) \\
\hline \multicolumn{3}{|c|}{ Area } \\
\hline square meter $\left(\mathrm{m}^{2}\right)$ & 0.0002471 & acre \\
\hline hectare (ha) & 2.471 & acre \\
\hline square hectometer $\left(\mathrm{hm}^{2}\right)$ & 2.471 & acre \\
\hline square kilometer $\left(\mathrm{km}^{2}\right)$ & 247.1 & acre \\
\hline hectare (ha) & 0.003861 & square mile $\left(\mathrm{mi}^{2}\right)$ \\
\hline square kilometer $\left(\mathrm{km}^{2}\right)$ & 0.3861 & square mile $\left(\mathrm{mi}^{2}\right)$ \\
\hline \multicolumn{3}{|c|}{ Volume } \\
\hline liter $(\mathrm{L})$ & 0.2642 & gallon (gal) \\
\hline cubic meter $\left(\mathrm{m}^{3}\right)$ & 264.2 & gallon (gal) \\
\hline cubic meter $\left(\mathrm{m}^{3}\right)$ & 35.31 & cubic foot $\left(\mathrm{ft}^{3}\right)$ \\
\hline cubic meter $\left(\mathrm{m}^{3}\right)$ & 1.308 & cubic yard $\left(\mathrm{yd}^{3}\right)$ \\
\hline cubic meter $\left(\mathrm{m}^{3}\right)$ & 0.0008107 & acre-foot (acre-ft) \\
\hline cubic hectometer $\left(\mathrm{hm}^{3}\right)$ & 810.7 & acre-foot (acre-ft) \\
\hline \multicolumn{3}{|c|}{ Flow rate } \\
\hline cubic meter per second $\left(\mathrm{m}^{3} / \mathrm{s}\right)$ & 70.07 & acre-foot per day (acre-ft/d) \\
\hline cubic meter per year $\left(\mathrm{m}^{3} / \mathrm{yr}\right)$ & 0.000811 & acre-foot per year (acre-ft/yr) \\
\hline meter per day $(\mathrm{m} / \mathrm{d})$ & 3.281 & foot per day $(\mathrm{ft} / \mathrm{d})$ \\
\hline cubic meter per second $\left(\mathrm{m}^{3} / \mathrm{s}\right)$ & 35.31 & cubic foot per second $\left(\mathrm{ft}^{3} / \mathrm{s}\right)$ \\
\hline liter per second $(\mathrm{L} / \mathrm{s})$ & 15.85 & gallon per minute (gal/min) \\
\hline \multicolumn{3}{|c|}{ Hydraulic conductivity } \\
\hline meter per day $(\mathrm{m} / \mathrm{d})$ & 3.281 & foot per day $(\mathrm{ft} / \mathrm{d})$ \\
\hline \multicolumn{3}{|c|}{ Hydraulic gradient } \\
\hline meter per kilometer $(\mathrm{m} / \mathrm{km})$ & 5.27983 & foot per mile (ft/mi) \\
\hline \multicolumn{3}{|c|}{ Transmissivity } \\
\hline meter squared per day $\left(\mathrm{m}^{2} / \mathrm{d}\right)$ & 10.76 & foot squared per day $\left(\mathrm{ft}^{2} / \mathrm{d}\right)$ \\
\hline
\end{tabular}

Temperature in degrees Celsius $\left({ }^{\circ} \mathrm{C}\right)$ may be converted to degrees Fahrenheit $\left({ }^{\circ} \mathrm{F}\right)$ as follows: ${ }^{\circ} \mathrm{F}$ $=\left(1.8 \times{ }^{\circ} \mathrm{C}\right)+32$.

Temperature in degrees Fahrenheit $\left({ }^{\circ} \mathrm{F}\right)$ may be converted to degrees Celsius $\left({ }^{\circ} \mathrm{C}\right)$ as follows: ${ }^{\circ} \mathrm{C}$ $=\left({ }^{\circ} \mathrm{F}-32\right) / 1.8$. 


\section{Datum}

Vertical coordinate information is referenced to the National Geodetic Vertical Datum of 1929 (NGVD 29). Horizontal coordinate information is referenced to the North American Datum of 1983 (NAD 83).

Altitude, as used in this report, refers to distance above the vertical datum.

\section{Abbreviations}

$\begin{array}{ll}\text { TBHM } & \text { Truxton Basin Hydrologic Model } \\ \text { USGS } & \text { U.S. Geological Survey }\end{array}$




\title{
Simulation of Groundwater-Level Changes from Projected Groundwater Withdrawals in the Truxton Basin, Northern Arizona
}

\author{
By Jacob E. Knight
}

\section{Abstract}

A three-dimensional, numerical groundwater flow model of the Hualapai Plateau and Truxton basin was developed to assist water-resource managers in understanding the potential effects of projected groundwater withdrawals on groundwater levels and storage in the basin. The Truxton Basin Hydrologic Model (TBHM) is a transient model that simulates the hydrologic system for the years 1976 through 2139, including hypothetical low-, medium-, and high-groundwater withdrawal scenarios beginning in 2020. The simulated effects of these withdrawal scenarios are presented as groundwater-level changes from the year 2020 to 2070, and from 2020 to 2140 . Hydrologic properties in the TBHM are derived from calibration of a steady-state model of the predevelopment (before 1976) groundwater system. The future pumping scenarios are each simulated with three different interpretations of basin depth supported by geophysical data. For each of the resulting nine transient models, a Monte Carlo approach is used to produce a range of possible and probable groundwater-level changes at points throughout the basin given probabilistic ranges of hydrologically reasonable aquifer property values supported by the model calibration results. The ensemble of models that simulate the future pumping scenarios include pumping from the existing well field (three wells) plus additional pumping from a proposed new well. Simulated high future pumping increases progressively to 1,840 acre-feet per year in 2120 and produces a range of drawdowns between 20 and 39 feet ( $\mathrm{ft}$ ) near the pumping center, with a median drawdown of $28 \mathrm{ft}$. The low future pumping scenario, which increases progressively to 650 acre- $\mathrm{ft}$ per year in 2120 , produces a range of drawdowns between 5 and $15 \mathrm{ft}$, with a median drawdown of $10 \mathrm{ft}$ at the same location over the same period of time.

\section{Introduction}

A three-dimensional, numerical groundwater flow model of the Hualapai Plateau and Truxton basin was developed to assist water-resource managers in understanding the potential effects of projected groundwater withdrawals on groundwater levels and storage in the basin. The Truxton Basin Hydrologic Model
(TBHM) was developed using previously published data as well as new geophysical data collected as part of this investigation (Ball, 2020; Kennedy, 2020). TBHM is a transient model that simulates the hydrologic system from the year 1976 through 2139, with the purpose of forecasting potential groundwater-level changes from the year 2020 to 2140 associated with three hypothetical groundwater withdrawal scenarios. The predevelopment (before 1976) groundwater system is simulated using a steady state model. The TBHM study area encompasses 1,200 square miles ( $\left.\mathrm{mi}^{2}\right)$, including the Truxton basin (approximately $75 \mathrm{mi}^{2}$ ) and much of the surrounding Hualapai Plateau (fig. 1). Natural groundwater recharge and discharge mostly occur in the Paleozoic and Permian rocks of the surrounding uplifted plateau. Potential future pumping scenarios are simulated in Truxton basin at the existing Peach Springs supply wells, herein referred to as the Truxton well field, and at a hypothetical new pumping location in the northern portion of the basin.

Forecasts of groundwater levels associated with proposed pumping scenarios are inherently uncertain. This uncertainty is often a result of a lack of data informing the selection of hydrologic properties of the aquifer system (the parameters for constructing the model) and limited historical observations of groundwater levels and flow (the system states for constructing the model) in the study area. In this study, forecast uncertainty stemming from unknown hydrologic properties is addressed by using a Monte Carlo approach, which produces a range of possible and probable outcomes given probabilistic ranges of hydrologically reasonable aquifer property values supported by the model calibration results. Limited historical observations of groundwater levels in the basin also create an uncertain starting point that influences the forecasted groundwater levels that result from simulated future pumping scenarios. For this reason, forecast results are presented as changes in groundwater levels after onset of simulated proposed pumping scenarios.

\section{Conceptual Model of the Groundwater- Flow System}

The conceptual model of a groundwater-flow system describes the spatial extent of the system, the location and rates 
of groundwater recharge and discharge, and important geologic features that affect groundwater flow. The current conceptual model of the groundwater-flow system in and around the Truxton basin is summarized in this section, with additional geologic detail provided in Mason and others (2020a). Truxton basin is the focus of this study, but the surrounding plateaus and canyons are included as part of the larger connected groundwater-flow system because implementing model boundaries that represent known physical boundaries of the groundwater system helps limit the model structural error and associated forecast uncertainty. As more data are collected, the conceptual model of this system may change to reflect new insights.

\section{Hydrogeologic Framework}

Most of the northeast and west peripheral boundaries of the groundwater-flow system in the Truxton basin are defined by hydrogeologic unit outcrops and geologic structural features (fig. 1; Mason and others, 2020a, their fig. 1), with the east and south boundaries defined by topographic, and presumed groundwater, divides. Uplift of the western Hualapai Plateau has exposed the entire hydrostratigraphic section important to groundwater flow. The west and south boundaries of the system follow the trace of exposed Proterozoic basement rock along the base of the Grand Wash Cliffs in the adjacent Hualapai Valley. Basement rock also is exposed in the Grand Canyon along the course of the Colorado River and along Diamond Creek in Blue Mountain Canyon. This bisection of the hydrostratigraphic section by these canyons marks the northeast boundary of the groundwater-flow system.

The eastern and southeastern extents of the system are less certain because the rocks of the aquifer are not exposed at land surface. A topographic divide along the Cottonwood Mountains serves as a proxy for a presumed groundwater divide that forms the southeastern extent of the flow system. The eastern extent follows the strike of Blue Mountain Fault. The fault might be a physical barrier to flow, or it might be coincident with a hydraulic barrier caused by the presumed direction of flow along it toward springs in the tributary canyons.

The Rampart Cave Member of the Cambrian Muav Limestone is the most important unit for groundwater flow on the western Hualapai Plateau (Mason and others, 2020a, their fig. 4). All springs of substantial volume discharge from this unit (Huntoon, 1977). The Rampart Cave Member is the structurally lowest member of the Muav Limestone, which overlies the impermeable Bright Angel Shale, which is also of Cambrian age (Mason and others, 2020a, their figs. 4 and 5). The shale effectively impedes vertical movement of groundwater, causing groundwater to mound beneath areas of recharge and flow laterally toward points of discharge in the tributary canyons (Huntoon, 1977).

Saturated Tertiary basin-fill sediments compose the Truxton basin aquifer, although saturated parts of older, underlying units may be locally important. The partly consolidated to consolidated gravel, sand, and clay sediments in the basin fill are moderately permeable and generally saturated west of the Hurricane Fault (fig. 1; Mason and others, 2020a). The basin-fill sediments overlie Proterozoic crystalline basement rock that was denuded of Paleozoic and Mesozoic cover following the Laramide uplift. The Proterozoic crystalline basement rock is considered impermeable except where fractured. Depth to basement is deepest along the axis of the basin owing to the presence of a large paleochannel in the underlying Proterozoic crystalline rock that has been identified in previous work (for example, Twenter, 1962; Elston and Young, 1991; Young and Hartman, 2014; Bills and Macy, 2016) and refined by recent geophysical surveys (Ball, 2020; Kennedy, 2020). Depths to basement range from more than 1,500 feet (ft) near the center of the basin to less than $500 \mathrm{ft}$ at the northeastern extent. The basin-fill sediments thin out completely to the southwestern extent where crystalline basement rock is exposed (Ball, 2020). East of the Hurricane Fault, lower Paleozoic carbonate rocks are still present above the crystalline basement. The alluvium basin fill that overlies these rocks is generally unsaturated (Mason and others, 2020a).

\section{Groundwater-Flow System}

Recharge of the Truxton basin groundwater-flow system occurs mostly in the higher altitudes of the Music and Cottonwood Mountains at the southwestern margin of the system (fig. 2). In the Music Mountains, water infiltrates downward through fractures in the exposed, unsaturated lower Paleozoic carbonates until it reaches the Rampart Cave Member of the Muav Limestone that overlies the Bright Angel Shale. Groundwater flow is assumed to be mainly horizontal, above the low-permeability shale, and to discharge at springs at the base of the Rampart Cave Member. Few springs are found in or stratigraphically below the shale. The Tapeats Sandstone beneath the Bright Angel Shale is saturated in places, but this water probably percolated through the shale at an extremely low rate over a long period of time (Huntoon, 1977). Groundwater recharge occurs in a similar manner in the Cottonwood Mountains along the southern margin of the groundwater system (fig. 2), but infiltrated water reaches saturated conditions in the Redwall Limestone, which is located above the Muav Limestone.

In the southwestern portion of the study area, groundwater flows mainly through dissolution-enhanced fractures of the Rampart Cave Member away from the western Hualapai Plateau recharge areas toward points of discharge in the tributary canyons of the Grand Canyon (fig. 2; Huntoon, 1977). In this area, the aquifer is unconfined and groundwater flow generally follows the dip to the northeast of the stratigraphic units that compose the plateau. Most discharge from the system occurs from springs at the base of the Rampart Cave Member in the tributary canyons of the Grand Canyon (Huntoon, 1977). A minor amount of flow, probably downward flow through fractures, discharges at small intermittent springs at the base of the Grand Wash Cliffs.

From the eastern Hualapai Plateau recharge areas in the southeastern portion of the study area, groundwater flows west-northwest toward Truxton basin, and north-northwest 


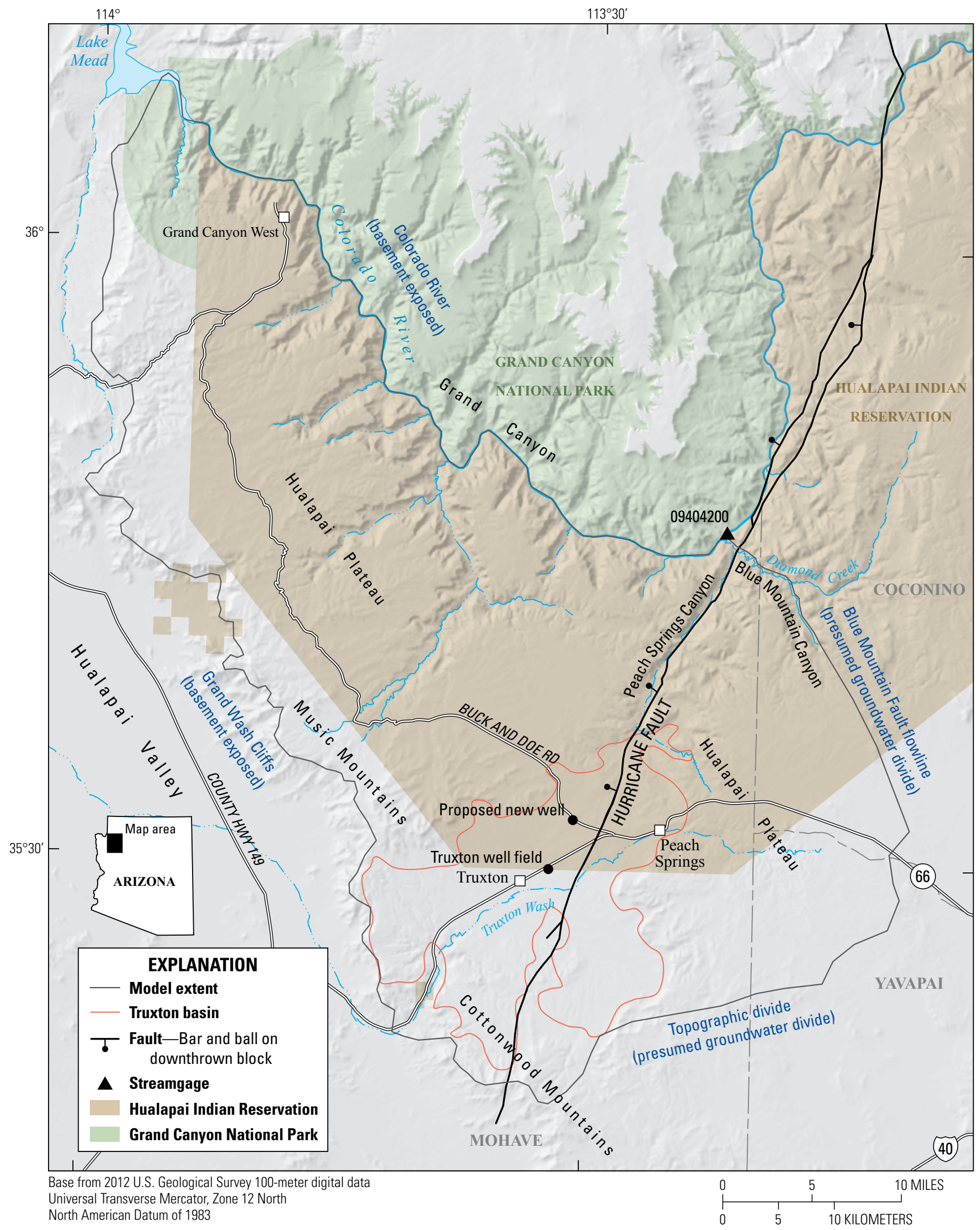

Figure 1. The Truxton basin groundwater-flow system boundaries. Faults modified from Arizona Bureau of Geology and Mineral Technology (1981), Beard and Lucchitta (1993), Richard and others (2000), and Billingsley and others (2006). 


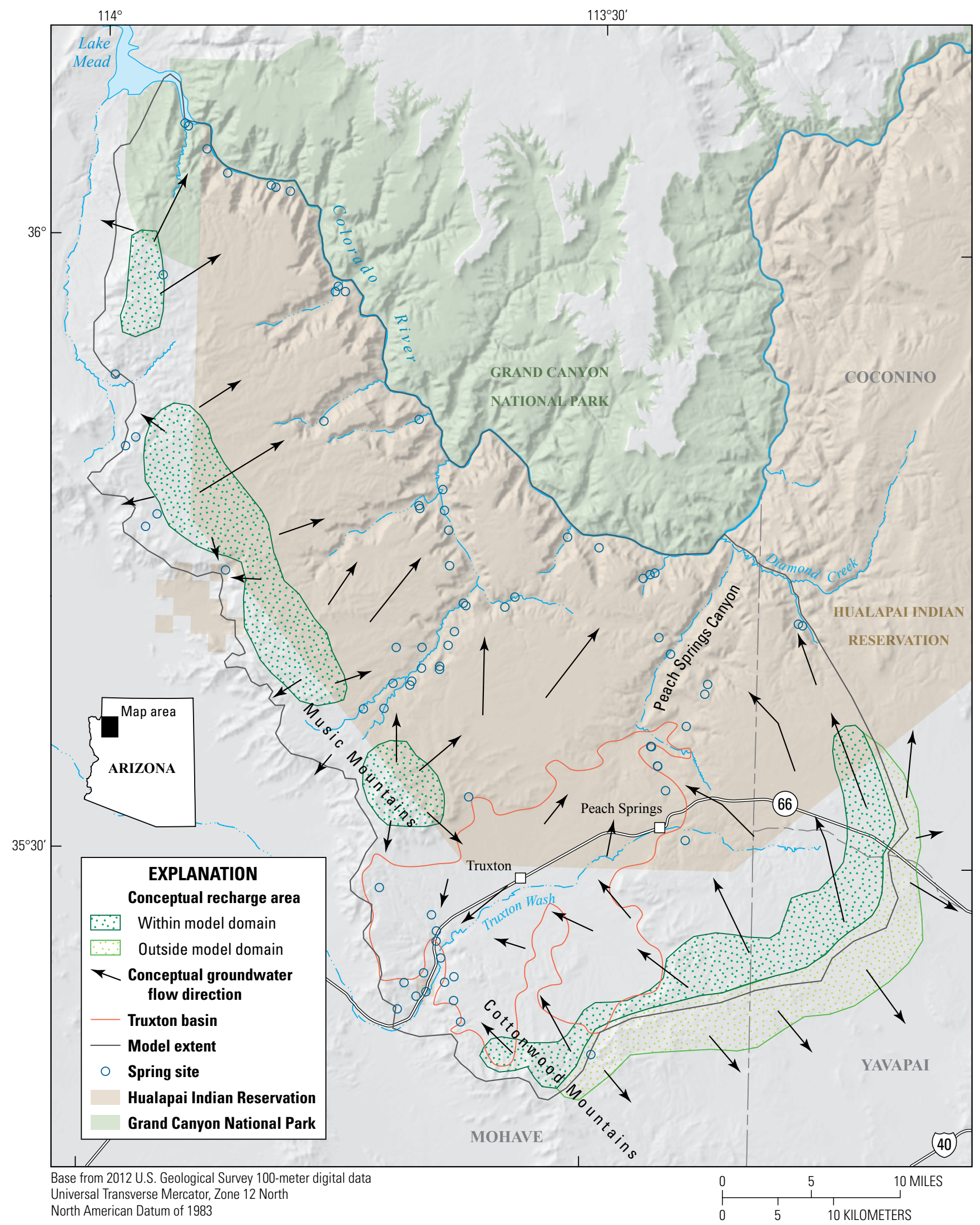

Figure 2. Conceptual model of the Truxton basin groundwater-flow system, including locations of groundwater recharge and discharge and groundwater-flow directions. 
to springs in Peach Springs Canyon and Diamond Creek (fig. 2). These recharge areas are located along a presumed groundwater divide (fig. 1). Groundwater on the opposite side of the divide flows to the southeast, away the study area.

Most inflow to the Truxton basin occurs as underflow from the saturated lower Paleozoic units of the eastern Hualapai Plateau that are in contact with the basin-fill sediments. A smaller volume of water enters the lower half of the Truxton basin from the northwest as mountain-front recharge coming off the Music Mountains. Very little water is thought to recharge directly to the basin owing to low precipitation and high potential evaporation rates (Huntoon, 1977).

Natural groundwater discharge from Truxton basin occurs as groundwater underflow, discharge to springs, and evapotranspiration. Outflow from the basin occurs both as discharge to Truxton Wash in the south and as underflow to the north (fig. 2). Groundwater pumping withdrawals have occurred since 1976 when the Truxton well field was developed for municipal supply. Withdrawal rates are estimated to have increased from 70 acre-feet per year (acre-ft/yr) in 1976 to $220 \mathrm{acre}-\mathrm{ft} / \mathrm{yr}$ in 2010 (Natural Resources Consulting Engineers, 2011).

\section{Groundwater Budget}

The groundwater budget for the study area includes estimates of natural inflows and outflows to the alluvial basin-fill sediments and contributing Paleozoic sedimentary and Proterozoic crystalline rocks of the groundwater-flow system. An annual predevelopment (before 1976) groundwater budget was developed to quantify the estimated volume of water flowing into and out of the regional groundwater-flow system. Huntoon (1977) estimated a minimum recharge rate to the western Hualapai Plateau of 3.85 cubic feet per second (approximately 2,800 acre-ft/yr) based on spring discharge measurements and estimates recorded between 1973-76. He noted that actual recharge to the western Hualapai Plateau could be several times larger than this estimate because he did not account for unknown rates of discharge from evapotranspiration. He further noted that the period of observation was characterized by below-average precipitation, which may not be an appropriate basis for determining a long-term average rate of recharge.

Huntoon's estimated minimum recharge rate to the western Hualapai Plateau was used as a starting point to develop an estimated predevelopment groundwater budget of the study area. Recharge rates and spatial distributions were estimated as described in the Boundary Conditions and Model Stresses section below. The majority of recharge and discharge in the region occurs in the groundwater systems of the western and eastern plateaus largely independent of each other. A relatively small amount of underflow likely enters the saturated basin-fill alluvium of the Truxton basin from the hydraulically connected lower Paleozoic carbonate rocks of the plateaus. A range of values for inflow and outflow components of the predevelopment groundwater system (table 1) reflect the uncertainty inherited from the historical discharge observations and the unknown magnitude of discharge through evapotranspiration.

\section{Simulation of Groundwater Flow}

The U.S. Geological Survey (USGS) groundwater-flow model, MODFLOW-NWT version 1.1.4 (Niswonger and others, 2011), using the included generalized-minimum-residual (GMRES) solver, was employed to simulate groundwater flow in the Truxton basin. MODFLOW-NWT is a version of MODFLOW-2005 that was designed to improve the numerical stability of unconfined groundwater-flow problems. FloPy version 3.2.12 (Bakker and others, 2016) was used to create and modify the MODFLOW input files, and to postprocess the output files. Automated parameter estimation was performed using PEST++ version 4.2.5 (White and others, 2019). PEST++ input and output were built and analyzed using the Python framework pyEMU version 0.6 (White and others, 2016). Model ensembles for forecast uncertainty analysis were run on the USGS Yeti supercomputer (U.S. Geological Survey, 2019b).

\section{Spatial Discretization}

The spatial discretization of the TBHM model grid consists of 4 layers with 208 rows and 333 columns, and it includes a total of 123,950 active cells. Model cells are 984.25 by $984.25 \mathrm{ft} \mathrm{(300}$ by 300 meters [m]) in the row and column direction, and have variable thickness based on interpolated contact elevations for the major hydrostratigraphic units interpreted from geophysical

Table 1. Estimated predevelopment groundwater-budget values for the western Hualapai Plateau, eastern Hualapai Plateau, and Truxton basin.

[Acre-ft/yr, acre-feet per year; n/a, not applicable]

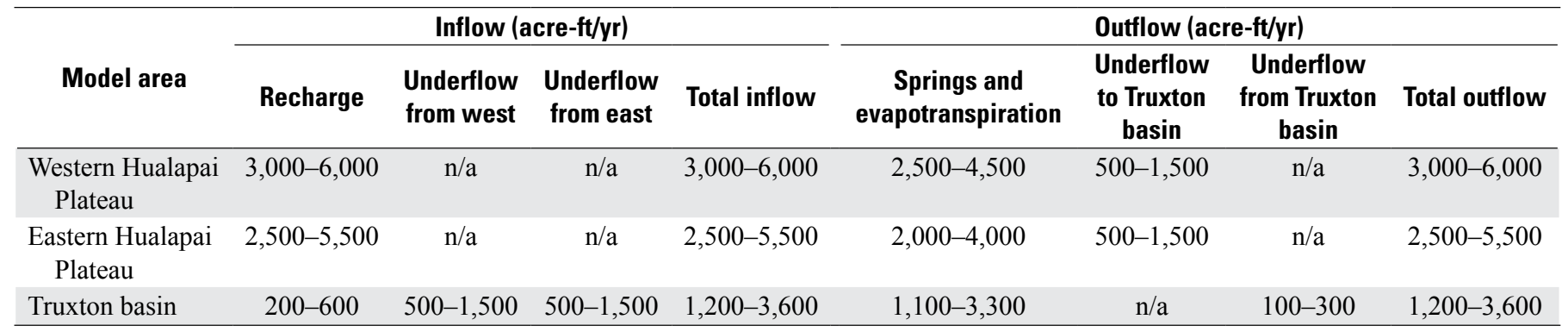


surveys documented in Ball (2020) and described below.

Horizontal dimensions were chosen to match the resolution of hydrostratigraphic surface elevations provided from geophysical data interpretations described in Ball (2020).

The TBHM model boundaries were chosen to approximate the groundwater system boundaries described in the conceptual model of this chapter and in Mason and others (2020a). Physical barriers to groundwater flow were used wherever possible to locate model boundaries; these are manifest around much of the lateral extent of the model where the entire sequence of hydrogeologic units are exposed by uplift and erosion. Presumed hydraulic barriers to groundwater flow such as groundwater divides were implemented as no-flow boundaries where necessary; these are less certain representatives of their natural system counterparts, which are difficult to locate without adequate data and can shift in location owing to changing stresses on the system. Boundaries that represent presumed hydraulic barriers to flow are assumed to be far afield from forecast locations of interest in the Truxton basin.

The model uses four layers and four aquifer-property zones to represent the three-dimensional extent of geologic strata that are (1) identifiable from geologic maps and geophysical data, and (2) have distinct properties affecting groundwater flow (fig. 3). Aquifer-property zone 1 is composed of undivided lower Paleozoic carbonates (layer 1) and the Rampart Cave Member of the Muav Limestone (layer 2). Zone 2 represents basin-fill alluvium in the Truxton basin and Milkweed Canyon and spans layers $1-3$. The utilization of layers $1-3$ to represent basin-fill alluvium above Proterozoic basement rock (fig. $3 B$ ) allows us to test the potential effects of vertical anisotropy within the sediments. Zone 3 represents the Bright Angel Shale and Tapeats Sandstone in layer 3. Zone 4 covers the entirety of layer 4 and represents Proterozoic crystalline basement rock; this bottom layer of the model is assigned a uniform thickness of $820 \mathrm{ft}(250 \mathrm{~m})$.

\section{Temporal Discretization}

TBHM is discretized into 13 stress periods aligned with temporal changes in estimated historical groundwater pumping rates and projected future pumping rates (table 2). The first stress period simulates predevelopment steady-state conditions prior to development of the Truxton well field, which began providing municipal water in 1976. Stress periods 2-6 simulate stepwise increases in estimated pumping rates from the Truxton well field from the years 1976 through 2019 based on population estimates (Natural Resources Consulting Engineers, 2011); the last estimate of pumping in 2010 was extended through 2019. Stress periods 7-13 simulate future pumping withdrawals from the Truxton well field and from a hypothetical new pumping location from 2020 through 2139. The timing and magnitude of these future pumping rates, and the placement of the hypothetical well, were provided by the Bureau of Reclamation (R. Thayer, written commun., 2019). Future pumping rates from the existing Truxton well field are simulated by three different scenarios, in which pumping rates progressively increase from 2020 to 2120 (table 2). In the low pumping scenario, withdrawals from the Truxton well field increase from $200 \mathrm{acre}-\mathrm{ft} / \mathrm{yr}$ in 2020 to $450 \mathrm{acre-ft/yr}$ in 2120. In the medium pumping scenario, withdrawals increase from 250 acre-ft/yr in 2020 to $810 \mathrm{acre}-\mathrm{ft} / \mathrm{yr}$ in 2120 . In the high pumping scenario, withdrawals increase from $350 \mathrm{acre-ft} / \mathrm{yr}$ in 2020 to $1,640 \mathrm{acre}-\mathrm{ft} / \mathrm{yr}$ in 2120 . In addition to existing well-field pumping, all three scenarios include withdrawal from a proposed new well that increases from 50 acre- $\mathrm{ft} / \mathrm{yr}$ in 2020 to $200 \mathrm{acre}-\mathrm{ft} / \mathrm{yr}$ in 2120 . The scenarios assume that no other withdrawals from the Truxton aquifer occur over this time period.

Table 2. Truxton Basin Hydrologic Model simulation stress periods.

[-, not applicable]

\begin{tabular}{|c|c|c|c|c|c|c|c|c|}
\hline \multirow{3}{*}{ Stress period } & \multirow{3}{*}{$\begin{array}{c}\text { Start date of } \\
\text { stess period } \\
\text { (month-day-year) }\end{array}$} & \multirow{3}{*}{$\begin{array}{c}\text { End date of } \\
\text { stess period } \\
\text { (month-day-year) }\end{array}$} & \multirow{3}{*}{$\begin{array}{l}\text { Period } \\
\text { length } \\
\text { (years) }\end{array}$} & \multirow{3}{*}{$\begin{array}{c}\text { Simulation } \\
\text { type }\end{array}$} & \multicolumn{4}{|c|}{ Simulated pumping (acre-feet per year) } \\
\hline & & & & & \multicolumn{3}{|c|}{ Truxton well field } & \multirow{2}{*}{$\begin{array}{c}\text { Proposed } \\
\text { new well } \\
\text { All } \\
\text { scenarios }\end{array}$} \\
\hline & & & & & $\begin{array}{c}\text { Low } \\
\text { scenario }\end{array}$ & $\begin{array}{l}\text { Medium } \\
\text { scenario }\end{array}$ & $\begin{array}{c}\text { High } \\
\text { scenario }\end{array}$ & \\
\hline 1 & Pre-1976 & $12 / 31 / 1975$ & - & Steady-state & - & - & - & - \\
\hline 2 & $1 / 1 / 1976$ & $12 / 31 / 1985$ & 10 & Transient & 78 & 78 & 78 & - \\
\hline 5 & $1 / 1 / 2000$ & $12 / 31 / 2009$ & 10 & Transient & 228 & 228 & 228 & - \\
\hline 6 & $1 / 1 / 2010$ & $12 / 31 / 2019$ & 10 & Transient & 247 & 247 & 247 & - \\
\hline 7 & $1 / 1 / 2020$ & $12 / 31 / 2039$ & 20 & Transient & 200 & 250 & 350 & 50 \\
\hline 8 & $1 / 1 / 2040$ & $12 / 31 / 2059$ & 20 & Transient & 210 & 300 & 400 & 100 \\
\hline 9 & $1 / 1 / 2060$ & $12 / 31 / 2069$ & 10 & Transient & 260 & 380 & 570 & 200 \\
\hline 13 & $1 / 1 / 2120$ & $12 / 13 / 2139$ & 20 & Transient & 450 & 810 & 1,640 & 200 \\
\hline
\end{tabular}


$\boldsymbol{A}$
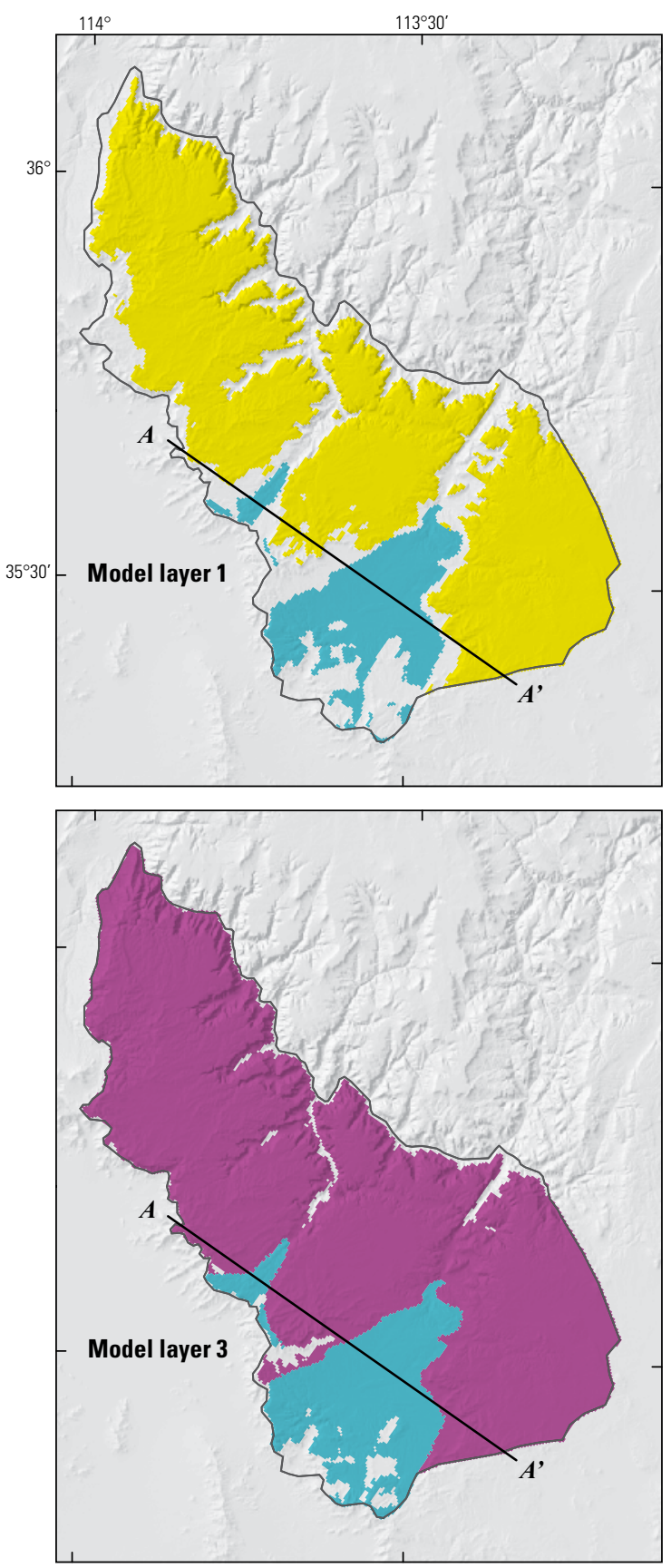

Base from 2012 U.S. Geological Survey 100-meter digital data Universal Transverse Mercator, Zone 12 North

North American Datum of 1983
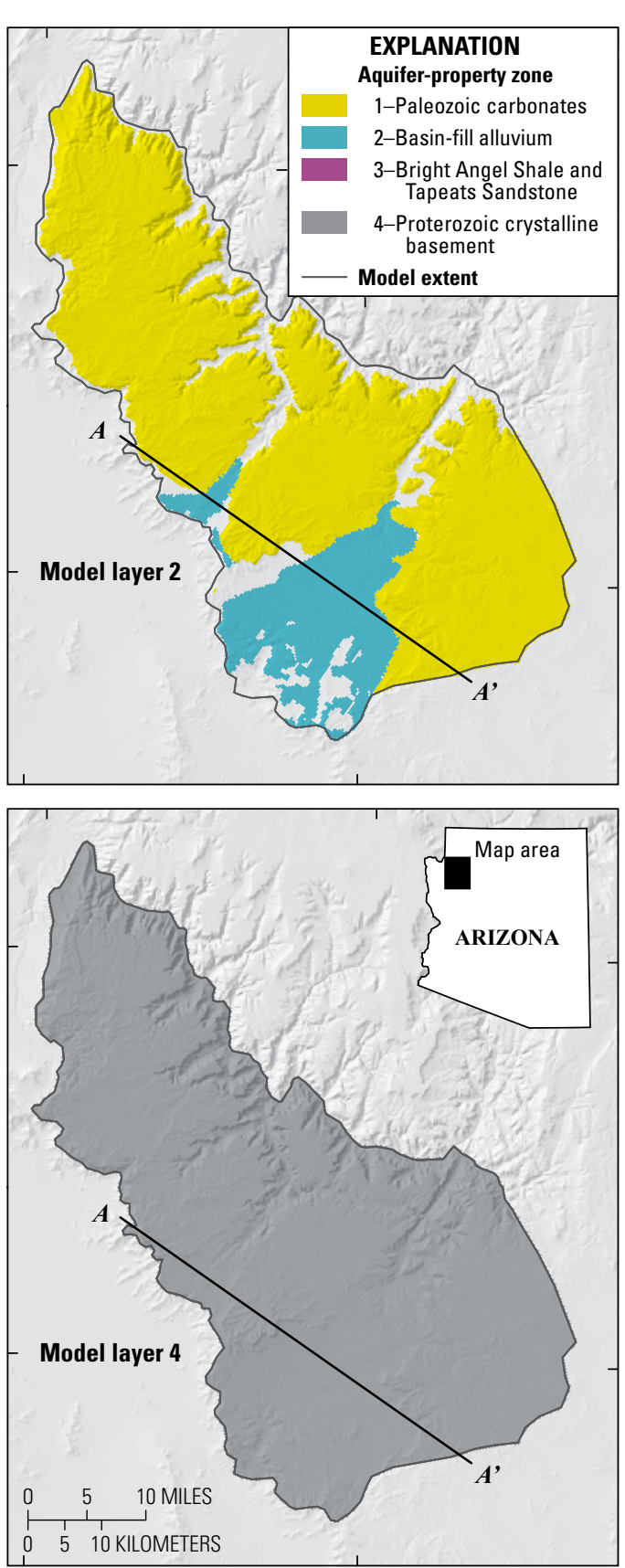

$B$

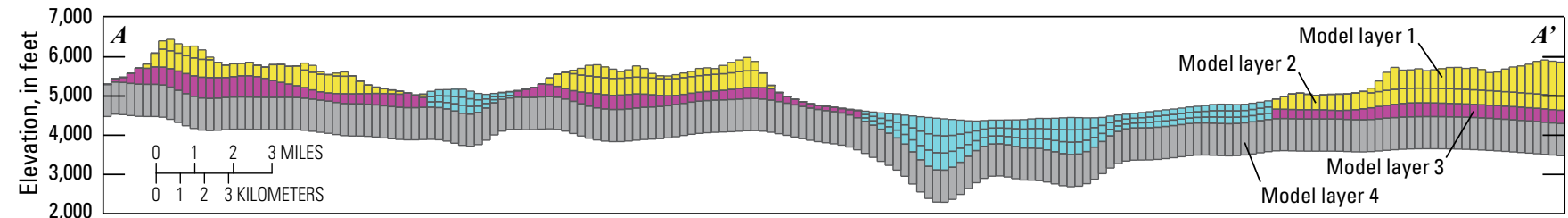

VERTICAL EXAGGERATION x5

Figure 3. Truxton Basin Hydrologic Model aquifer-property zones by model layer in $(A)$ map view and $(B)$ in cross section. 


\section{Boundary Conditions and Model Stresses}

TBHM uses specified-flux, specified-head, and headdependent boundary conditions to represent sources and sinks to the aquifer system, as well as areas where the

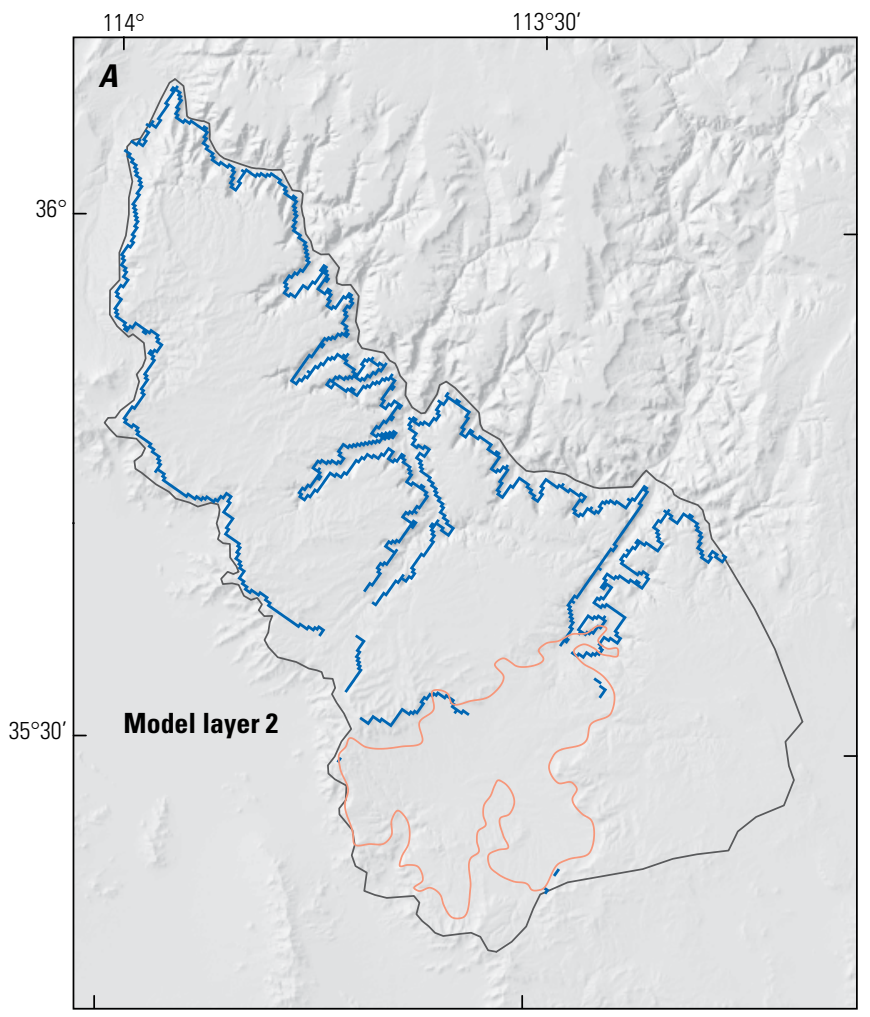

Base from 2012 U.S. Geological Survey 100-meter digital data Universal Transverse Mercator, Zone 12 North North American Datum of 1983 aquifer head is approximated to be constant through time (fig. 4). This section contains a discussion of the assumptions used for locating and simulating each boundary condition, and describes their implementation using the relevant MODFLOW-NWT packages.
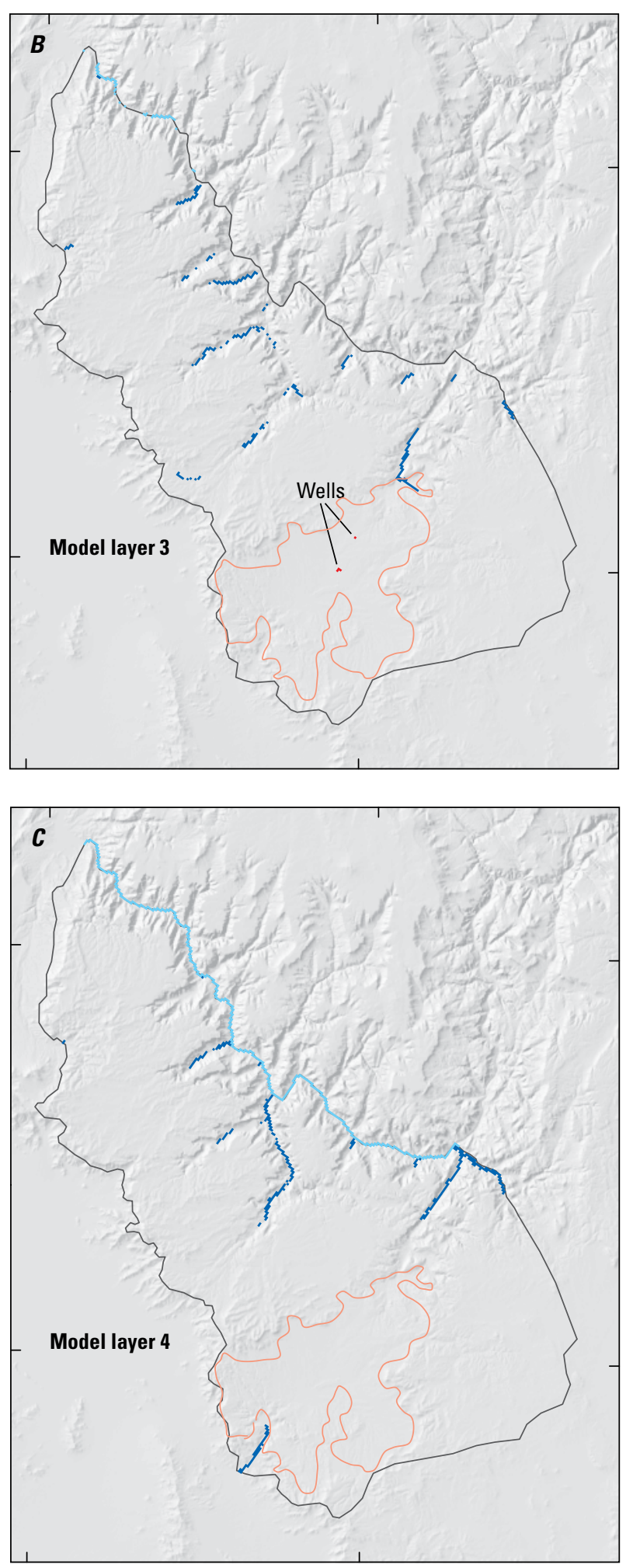

Figure 4. Location of drain cells, constant-head cells, and groundwater withdrawals in the Truxton Basin Hydrologic Model: $(A)$ layer $2,(B)$ layer $3,(C)$ layer 4 . There are no specialized boundary condition cells in layer 1. 


\section{Colorado River}

The Colorado River is the northern hydrologic boundary of the model area and is simulated as a specified head boundary condition using the MODFLOW BAS package (fig. 4). The top active cell in every row/column location that intersects the river is assigned a head value roughly equal to the stage of the river that is approximated to remain constant through the entire simulation. A USGS stream gage is located on the Colorado River above the mouth of Diamond Creek (USGS 09404200) close to the most upstream model cell that represents the river (fig. 1). The gage has automatically recorded stage elevations between approximately 1,385 and 1,395 $\mathrm{ft}$ above the National Geodetic Vertical Datum of 1929 (NGVD 29) since 2007, and historical measurements at the same gage since 1989 are within the same range (U.S. Geological Survey, 2018). Stage elevation at the most downstream model cell was roughly approximated using a 10-m digital elevation model. An elevation of $1,390 \mathrm{ft}$ was chosen for the most upstream model cell and linearly interpolated along model columns to an elevation of $1,204 \mathrm{ft}$ at the most downstream cell.

\section{Groundwater Recharge}

Groundwater recharge is simulated in TBHM as a specifiedflux boundary condition using the MODFLOW RCH package. A spatially distributed recharge flux is applied to the top active layer cell of each row/column grid location. If active cells are simulated to be dry, the recharge flux is applied to the top non-dry cell. An estimated long-term average recharge rate is held constant throughout the historical transient simulation. Seasonal variability is ignored because model forecasts are concerned with decadalscale changes in groundwater levels associated with projected groundwater withdrawal rates. Uncertainty of long-term changes in future recharge is addressed in the forecast period using a parameter that multiplies the estimated long-term average recharge rate by a relative factor between 0.75 and 1.25 .

A variation of the Maxey-Eakin recharge estimation method (Maxey and Eakin, 1949) was developed to produce a spatial distribution of recharge (fig. 5). Maxey and Eakin described an empirical relation between precipitation and recharge as a step function in which the fraction of precipitation assumed to become recharge increases with increasing precipitation (fig. 5, line A). The variation employed here is based on a method used in a previous model of the Death Valley regional groundwater-flow system (D'Agnese and others, 1998). The method converts the series of Maxey-Eakin bins that relate precipitation and recharge into a three-term polynomial equation with precipitation as the independent variable using a best-fit line (fig. 5, line B). The polynomial coefficients $\mathrm{a}, \mathrm{b}$, and $\mathrm{c}$ can then be manually adjusted to change the slope and $\mathrm{x}$-intercept of the polynomial. A steeper line will increase the disparity between the fraction of recharge assumed at locations with higher precipitation compared to locations with lower precipitation. The $\mathrm{x}$-intercept is effectively a lower bound for the precipitation rate below which the fraction of recharge is zero.

A raster image of long-term average precipitation (Mason and others, $2020 \mathrm{~b}$, their fig. $2 B$ ) was projected onto the top layer of the model grid. The polynomial described above was used to calculate the fraction of precipitation assumed to become recharge in each grid cell, which was then multiplied by the precipitation rate in each cell to return a two-dimensional array of recharge rates (fig. 6). This array was masked to include only cells where the top active layer represents either basin-fill sediment or carbonate rock. Recharge was assumed to be zero in cells where the top active layer represents crystalline basement rock or shale.

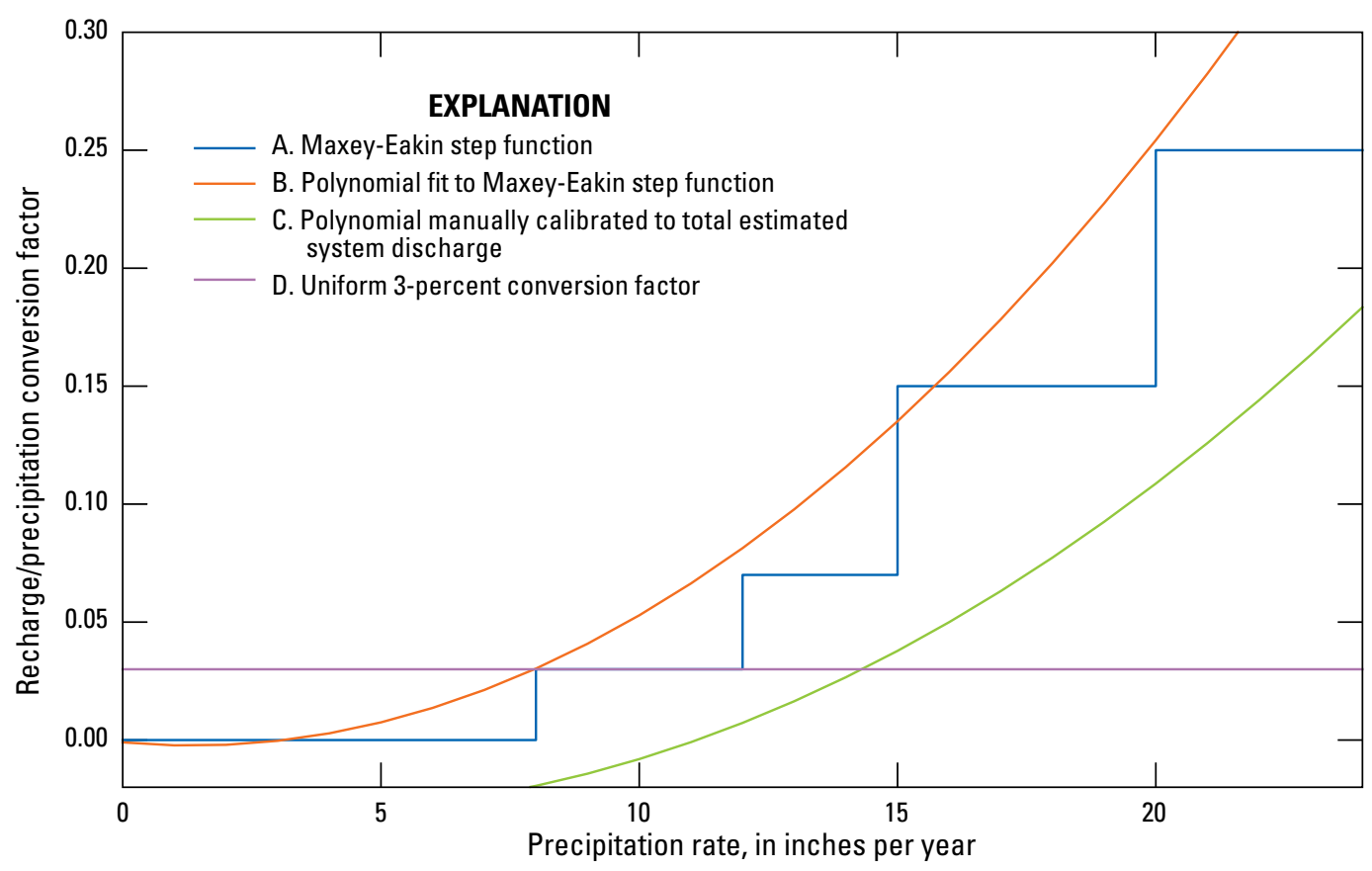

Figure 5. Functions considered to convert spatially distributed rates of long-term average precipitation to recharge rates for the Truxton Basin Hydrologic Model. 


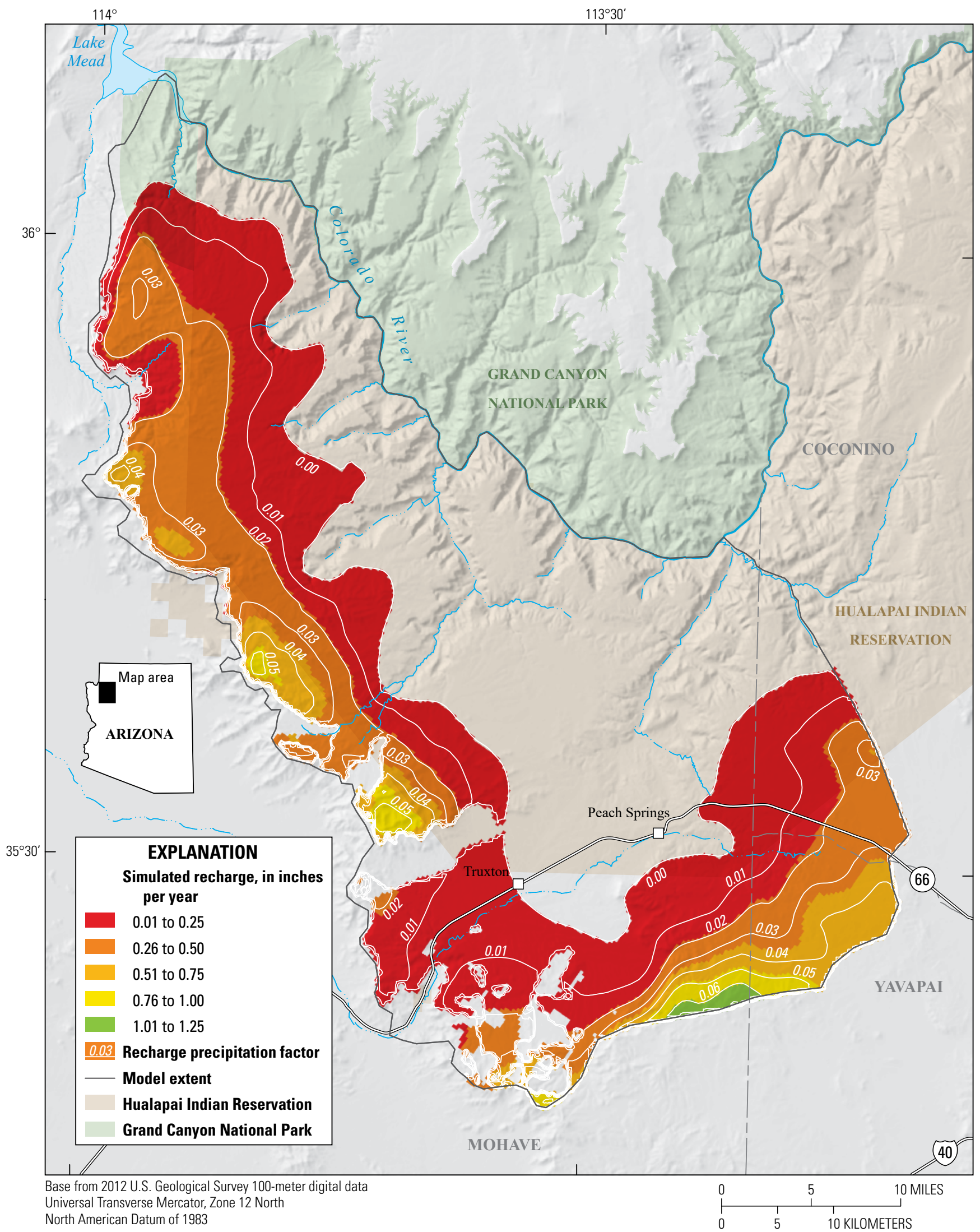

Figure 6. Modified Maxey-Eakin, precipitation-to-recharge conversion factors (contours), in inches per inch, and the resulting recharge distribution, in inches per year. One cell had a value slightly larger than 1.25 inches per year but is too small to show at map scale. 
The polynomial approximation of the Maxey-Eakin function used to calculate rates of recharge in TBHM (table 3 and fig. 5, line C) was manually calibrated by adjusting the polynomial coefficients until the following conditions were met: (1) the sum of recharge covering the western Hualapai Plateau is equal to approximately 50 percent more than the previous minimum estimate (Huntoon, 1977) to account for unobserved evapotranspiration; (2) the sums of recharge covering the Truxton basin and eastern Hualapai Plateau are reasonable relative to the western Hualapai Plateau; and (3) the pattern of recharge distribution aligns with the modeler's assumptions about the relative spread or concentration of areas that supply recharge to the groundwater system. For example, a given polynomial might produce a recharge array that sums to reasonable quantities over the plateaus and basin but is too evenly distributed over the entire active model area. This distribution would be rejected because it violates the assumption that recharge is disproportionately greater in higher altitude areas that receive more precipitation and have lower potential evaporation rates. Recharge rates applied to the TBHM are substantially smaller than would be calculated using an unmodified Maxey-Eakin approach but maintain a spatial distribution with higher rates of recharge concentrated in the areas of the model where more precipitation occurs (table 3). A uniform conversion factor of 0.03 (fig. 5, line D) was considered as a simple alternative to the Maxey-Eakin step function or the polynomial approximation. This factor was previously suggested (Natural Resources Consulting Engineers, 2011) because most of the study area receives between 8-12 inches per year of precipitation, which corresponds to the 3-percent recharge/ precipitation bin of the Maxey-Eakin step function.

\section{Groundwater Withdrawals}

Groundwater withdrawals are simulated as specified-flux boundary conditions using the MODFLOW WEL package. Three existing wells in the Truxton well field were located on the model grid and assigned to layer 3 based on the reported depth of the wells (table 4; fig. 4). Estimated historical groundwater pumping rates were assigned to each of the three wells as a portion of total estimated withdrawals in each stress period based on their relative reported pumping capacities (Natural Resources Consulting Engineers, 2011), but this distinction is likely unimportant given the close proximity of the wells to each other.

A hypothetical well located on Buck and Doe Road, 2 miles west of U.S. Route 66 (fig. 1), was created for inclusion in future pumping scenarios. The location was selected by the Bureau of Reclamation based on road access and basin depth revealed by geophysical data presented in Mason and others (2020b). This hypothetical well was simulated in layer 3 (fig. $4 B$ ).

\section{Groundwater Discharge to Springs and Evapotranspiration}

Groundwater lost to riparian evapotranspiration is implicitly lumped with spring and seep discharge simulated as headdependent flux boundary conditions (fig. 7) by the MODFLOW DRN package (Harbaugh, 2005). Available data were insufficient to develop model parameters for the MODFLOW EVT package (Harbaugh, 2005), which requires knowledge of type and location of vegetation, root depth, and soil type. Instead, unobserved discharges like base flow and evapotranspiration are accounted for

Table 3. Comparison of total recharge flux resulting from application of different precipitation/recharge relations.

[TBHM, Truxton Basin Hydrologic Model]

\begin{tabular}{|c|c|c|c|c|}
\hline \multirow{2}{*}{ Precipitation-to-recharge calculation method } & Western Hualapai Plateau & Eastern Hualapai Plateau & Truxton basin & Total recharge \\
\hline & \multicolumn{4}{|c|}{ Acre-feet per year } \\
\hline Maxey-Eakin step function & 20,000 & 15,600 & 1,800 & 37,400 \\
\hline Uniform 3-percent conversion factor & 11,300 & 7,000 & 1,300 & 19,600 \\
\hline $\begin{array}{l}\text { Polynomial calibrated to match total estimated } \\
\text { system discharge (simulated in TBHM) }\end{array}$ & 4,500 & 4,100 & 200 & 8,800 \\
\hline
\end{tabular}

Table 4. Production wells simulated in the Truxton Basin Hydrologic Model. Existing well specifications from Natural Resources Consulting Engineers (2011).

[ft, feet; gpm, gallons per minute; -, not available]

\begin{tabular}{llcccc}
\hline Well name & Well location & $\begin{array}{c}\text { Model cell index } \\
\text { (layer, row, column) }\end{array}$ & $\begin{array}{c}\text { Screen top } \\
\text { depth (ft) }\end{array}$ & $\begin{array}{c}\text { Screen bottom } \\
\text { depth (ft) }\end{array}$ & $\begin{array}{c}\text { Well yield } \\
\text { (gpm) }\end{array}$ \\
\hline GW001 & Existing well field & $3,134,235$ & 528 & 623 & 145 \\
GW002 & Existing well field & & 609 \\
GW003 & $3,133,235$ & 425 & 65 \\
GW004 (hypothetical) & Existing well field ${ }^{1}$ & $3,133,236$ & 440 & 650 & - \\
\hline
\end{tabular}

${ }^{1}$ Current Truxton basin well field. 


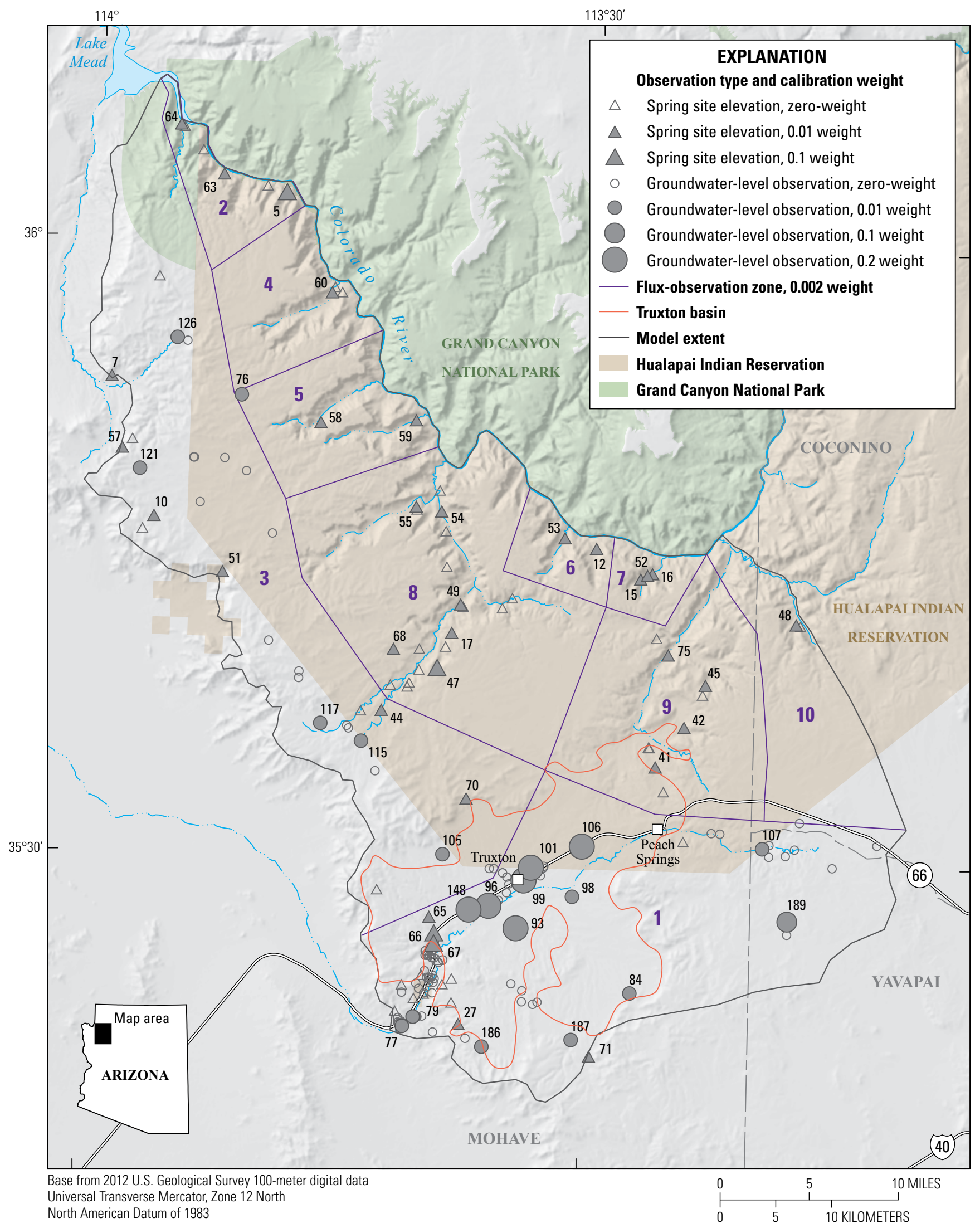

Figure 7. Well and spring locations and flux-observation zones simulated in the Truxton Basin Hydrologic Model. Labels indicate observation ID in appendix tables 1.1 and 1.2 . 
in the calibration process by creating targets of simulated discharge that are greater than observed spring discharges by approximately 50 percent. The DRN package requires a drain elevation and conductance factor for each model cell that is assigned a drain feature. Discharge is zero unless simulated head in the model cell is greater than the specified drain elevation, at which point discharge is calculated as the difference in heads multiplied by the conductance factor.

Drain features are assigned to model cells (fig. 4) that occupy one of the following settings: (1) the model cell represents Cambrian Muav Limestone (model layer 2, aquifer-property zone 1) and is exposed on at least one cell side; or (2) the model cell of the top active layer represents Cambrian Muav Limestone (model layer 2, aquifer-property zone 1), Bright Angel Shale (model layer 3 , aquifer-property zone 3 ), or Proterozoic basement (model layer 4, aquifer-property zone 4 ) and intersects a surface drainage polyline shapefile projected onto the model grid. Surface drainage shapefiles were obtained from the National Hydrography Dataset (U.S. Geological Survey, 2019a).

Drain features placed in setting 1 account for springs and seeps that discharge from the Cambrian Muav Limestone exposed in tributary canyon walls. Springs in this setting account for nearly all observed groundwater discharge on the Hualapai Plateau (Huntoon, 1977). The drain elevations are specified to be just above the bottom elevations of the containing cells, reflecting that most observed springs in this setting discharge from the base of the Muav Limestone.

Drain features placed in setting 2 account for groundwater discharge at the base of the lower reaches of the tributary canyons. This type of groundwater discharge is mostly unobserved, with the notable exception of base flow to Truxton Wash. The drain elevations in this setting are specified to be just below the top elevations of the containing cells, which are roughly equal to land surface.

\section{Groundwater-Flow Model Calibration Approach}

The TBHM was calibrated to identify a set of model parameter values that resulted in the minimum difference (error) between observed and simulated heads and estimated flows that represent predevelopment steady-state conditions. Parameters that represent aquifer properties were estimated at pilot points and interpolated to the remainder of the cells within each aquiferproperty zone. Constraints were built into the calibration process to produce a set of parameters that are hydrologically reasonable and comport with the current understanding of the hydrogeologic system. The parameter estimation software PEST++ was utilized to find parameter values that minimize the residuals between the weighted target observations described below and their simulated equivalents, balanced with the penalties incurred by selecting parameter values that violate the preferred homogeneity within aquifer-property zones imposed by first-order Tikhonov regularization. Together, these two outcomes make up the objective function that the PEST + software seeks to minimize during a calibration run.
Groundwater responses to withdrawals and recharge are highly sensitive to the hydraulic conductivity and storage parameters in the model (Barlow and Leake, 2012). The values of these parameters are typically inferred though a calibration procedure, during which the parameter values are adjusted until the groundwater conditions simulated by the model match observed conditions. The calibration of storage parameters requires a time series of groundwater-level observations coupled with known rates of groundwater withdrawal at a particular location, which was not readily available within the study area.

It was determined there was not enough of a record of groundwater-level changes over time and too much uncertainty in timing and magnitude of past groundwater withdrawals to attempt calibration by way of history matching with a transient model. A steady-state model calibration allowed for estimates of horizontal hydraulic conductivity, horizontal and vertical anisotropy, recharge distributions, and conductance factors for head-dependent flux cells. Storage properties are irrelevant to steady-state simulations, so specific yield and specific storage parameters were not identified through the calibration process; their contribution to forecast uncertainty is detailed in the Forecasting Simulations and Uncertainty Analysis section below.

\section{Hydraulic Properties Estimated in Model Calibration}

Hydraulic properties and system stresses considered in the model calibration process included horizontal hydraulic conductivity, horizontal and vertical anisotropy, head-dependent flux conductance, and groundwater-recharge distribution. Initial values of aquifer system properties for each hydrostratigraphic unit of the study area (table 5) were selected from within published ranges (Freeze and Cherry, 1979) (table 6) and a previous report on the study area (Natural Resources Consulting Engineers, 2011).

Model cells were assigned initial (precalibration) aquifer property values in a piecewise-constant manner according to their representative hydrostratigraphic unit (fig. 3). These initial values were later adjusted by aquifer-property zone during manual calibration and allowed to vary internally by way of interpolation within each zone from pilot-point values estimated in the automated parameter estimation process.

\section{Groundwater-Level Observations and Groundwater Discharge Estimates Used in Model Calibration}

Groundwater-level observations (table 1.1) and spring site elevations (table 1.2) were used as history matching targets in TBHM (fig. 7). Flux-observation zones were created to assign additional history matching targets of estimated long-term average groundwater discharge (fig. 7). Discharge estimates were derived by choosing a representative volumetric discharge for each fluxobservation zone based on available historical measurements of spring discharge (Huntoon, 1977; U.S. Geological Survey, 2018) and (or) stream discharge (U.S. Geological Survey, 2018). To account for discharge such as unmapped springs and riparian evapotranspiration, the estimate was increased by 50 percent. The 
Table 5. Initial hydraulic property parameter values for each aquifer-property zone of the Truxton Basin Hydrologic Model.

[ft, feet]

\begin{tabular}{lcccc}
\hline \multicolumn{1}{c}{ Model parameter } & $\begin{array}{c}\text { Zone 1- } \\
\text { Undivided lower Paleozoic } \\
\text { carbonates }\end{array}$ & $\begin{array}{c}\text { Zone 2- } \\
\text { Basin fill }\end{array}$ & $\begin{array}{c}\text { Zone 3- } \\
\text { Bright Angel } \\
\text { Shale }\end{array}$ & $\begin{array}{c}\text { Zone 4- } \\
\text { Proterozoic } \\
\text { basement }\end{array}$ \\
\hline Horizontal hydraulic conductivity (ft/day) & 1.6 & 9.8 & 0.03 & 0.03 \\
\hline Vertical anisotropy & 2 & 2 & 10 & 10 \\
\hline Horizontal anisotropy & 2 & 1 & 1 & 1 \\
\hline Specific yield & 0.05 & 0.10 & 0.03 & 0.01 \\
\hline Specific storage $\left(\mathrm{ft}^{-1}\right)$ & $3 \mathrm{E}^{-06}$ & $6 \mathrm{E}^{-05}$ & $3 \mathrm{E}^{-06}$ & $3 \mathrm{E}^{-06}$ \\
\hline Drain conductance $\left(\mathrm{ft}^{2} / \mathrm{day}\right)$ & 10,764 & 10,764 & 10,764 & 10,764 \\
\hline
\end{tabular}

Table 6. Lower- and upper-bounds for estimated hydraulic property parameter values within aquifer-property zones of the Truxton Basin Hydrologic Model.

[ft, feet]

\begin{tabular}{lcccc}
\hline \multicolumn{1}{c}{ Model parameter } & $\begin{array}{c}\text { Zone 1- } \\
\text { Undivided lower Paleozoic } \\
\text { carbonates }\end{array}$ & $\begin{array}{c}\text { Zone 2- } \\
\text { Basin fill }\end{array}$ & $\begin{array}{c}\text { Zone 3- } \\
\text { Bright Angel } \\
\text { Shale }\end{array}$ & $\begin{array}{c}\text { Zone 4- } \\
\text { Proterozoic } \\
\text { basement }\end{array}$ \\
\hline Horizontal hydraulic conductivity (ft/day) & $0.15-6.5$ & $3-33$ & $0.003-0.3$ & $0.003-0.3$ \\
Vertical anisotropy & $1-100$ & $1-100$ & $2-100$ & $2-100$ \\
Horizontal anisotropy & $1-10$ & $1-10$ & $1-10$ & $1-10$ \\
Specific yield & $0.01-0.18$ & $0.05-0.25$ & $0.01-0.1$ & $0.001-0.05$ \\
Specific storage $\left(\mathrm{ft}^{-1}\right)$ & $3 \mathrm{E}^{-07}-3 \mathrm{E}^{-05}$ & $3 \mathrm{E}^{-06}-3 \mathrm{E}^{-04}$ & $3 \mathrm{E}^{-07}-3 \mathrm{E}^{-05}$ & $4 \mathrm{E}^{-08}-3 \mathrm{E}^{-06}$ \\
Drain conductance $\left(\mathrm{ft}^{2} /\right.$ day) & $5,000-20,000$ & $5,000-20,000$ & $5,000-20,000$ & $5,000-20,000$ \\
\hline
\end{tabular}

resulting flow estimates are used as flux calibration targets for the total amount of discharge simulated in each flux-observation zone (table 7). The flux-observation zone estimates contain a high level of uncertainty, but the grand total was determined to provide a useful approximation of the total volumetric flow that should be simulated by the model, providing a constraint for the recharge distribution process described below.

\section{Calibration Target Weights}

Weights, which represent a qualitative and relative assessment of each observation's proper degree of influence on model calibration, were assigned to groundwater-level observations and spring site elevations (tables 1.1 and 1.2; fig. 7). Groundwater-level observations from wells in the Truxton basin were given the highest weight (0.2). Groundwater-level observations from wells and site elevations of springs in the Bright Angel Shale or Proterozoic basement were given the lowest nonzero weight (0.01). Zero-weights were assigned to groundwater-level observations and spring site elevations of the top model layer in the aquifer-property zone that represented lower Paleozoic carbonates above the Cambrian Muav Limestone. These observations generally relate to perched systems unrelated to regional groundwater flow (Huntoon, 1977). Zero-weights were also assigned to observations deemed to be of low confidence or redundant with nearby observations. This removes any influence by these observations on the automated parameter estimation process but retains a record of the observations to compare with their simulated equivalents.

Flux targets were created for each of the flux-observation zones described previously (fig. 7). The targets represent total estimated discharge from spring flow and evapotranspiration in each flux-observation zone. The simulated equivalent of these targets is the sum of discharges simulated at the drain-type boundary condition cells in each flux-observation zone (fig. 7). Using this method, the approximate magnitude of discharge within each flux-observation zone can be reasonably simulated by the model without placing too much importance on sporadic observations made at different times under different conditions at specific point locations of mapped springs.

\section{Method of Model Calibration}

The TBHM was iteratively calibrated to match target heads and flows in two phases: (1) manual trial and error, and (2) automated parameter estimation. Manual modifications to the 
Table 7. Estimated long-term average groundwater discharge by springs and evapotranspiration in each flux-observation zone of the Truxton Basin Hydrologic Model (see fig. 6 for flux-observation zone locations).

\begin{tabular}{clr}
\hline $\begin{array}{c}\text { Flux-observation zone } \\
\text { number }\end{array}$ & Flux-observation zone name & $\begin{array}{c}\text { Estimated total discharge by } \\
\text { springs and evapotranspiration } \\
\text { (acre-feet/year) }\end{array}$ \\
\hline 1 & Truxton Wash & 1,100 \\
\hline 2 & Columbine Falls & 250 \\
\hline 3 & Grand Wash Cliffs & 40 \\
\hline 4 & Quartermaster Canyon & 1,300 \\
5 & Reference Point/Lost Creek & 250 \\
6 & Bridge Canyon & 250 \\
\hline 7 & Travertine Canyon & 250 \\
8 & Spencer Canyon & 2,200 \\
9 & Peach Springs Canyon & 850 \\
10 & Blue Mountain Canyon & 1,750 \\
\hline
\end{tabular}

model were used to gain a better understanding of the system and discover reasonable values of aquifer property parameters that could be input to the automated parameter estimation code as initial estimates. The automated parameter estimation code was used to fine-tune the distribution of property values within aquifer-property zones and calculate parameter identifiability and sensitivity to target observations. Parameters of low identifiability were fixed to manually assigned values and the iterative process was repeated until the model adequately matched target observations using parameter values considered to be reasonable. Through several iterations, fixed values were assigned to recharge distribution factors as well as horizontal and vertical anisotropy. Horizontal hydraulic conductivity and drain conductance factors remained adjustable for the automated parameter estimation phase. Automated parameter estimation was performed using the PESTPP-GLM code of the PEST++ (ver. 4.2.5) software (White and others, 2019). PESTPP-GLM allows for highly parameterized inversion with Tikhonov regularization (Doherty and others, 2010), which utilizes observations and (or) prior information equations of parameter values or the relation between parameter values to constrain the parameter optimization process. The objective function in this case is a combination of two subparts: (1) the measurement objective function, which is the sum of the squared weighted differences between observed and simulated states; and (2) the regularization objective function, which is a measure of how much the selected parameter values violate soft knowledge of the system. The calibration process for TBHM used first-order Tikhonov regularization to favor homogeneous distributions of aquifer property parameters unless otherwise supported by observational data. This preferred, but flexible, condition of homogeneity is implemented by adding to the regularization objective function inverse-distance-weighted penalties for differences between parameter values estimated at pilot points within an aquifer-property zone.
Incorporating regularization schema into the calibration of a highly parameterized model helps avoid overfitting the model to the data, which often results in parameter fields with a bull's eye or scatter-shot effect that is not strongly supported by knowledge of the hydrogeologic system. Aquifer property parameter values within each aquifer-property zone were estimated at pilot-point locations (fig. 8) and interpolated to the rest of the active cells within their zone using kriging factors calculated by pyEMU. Pilot points were spaced every 20 cells in the carbonate zone, every 10 cells in the basin-fill sediment zone, and every 30 cells in both the shale zone and the basement zone.

\section{Calibration Results}

TBHM was calibrated to groundwater-level observations and estimated groundwater discharge using a combined trial-anderror and automated parameter-estimation approach described previously. The resulting model contains parameter values which are generally in agreement with the ranges of reasonable values identified in the conceptual model (table 6). Early in the iterative process, polynomial coefficients for the modified Maxey-Eakin function were selected to produce spatial arrays of recharge rates that comported with prior assessments of the western Hualapai Plateau (Huntoon, 1977) and resulted in reasonable rates across the remainder of the model area. Horizontal and vertical anisotropy were assigned fixed values after several iterations of automated parameter estimation indicated that observations did not provide enough information to estimate these parameters uniquely. Horizontal anisotropy is defined in MODFLOW as the ratio of hydraulic conductivity in the column direction over the hydraulic conductivity in the row direction (hkcol/hkrow). Horizontal anisotropy was fixed to a value of 2.0 in aquifer-property zone 1 (Paleozoic carbonates) and 1.0 everywhere else. Vertical 

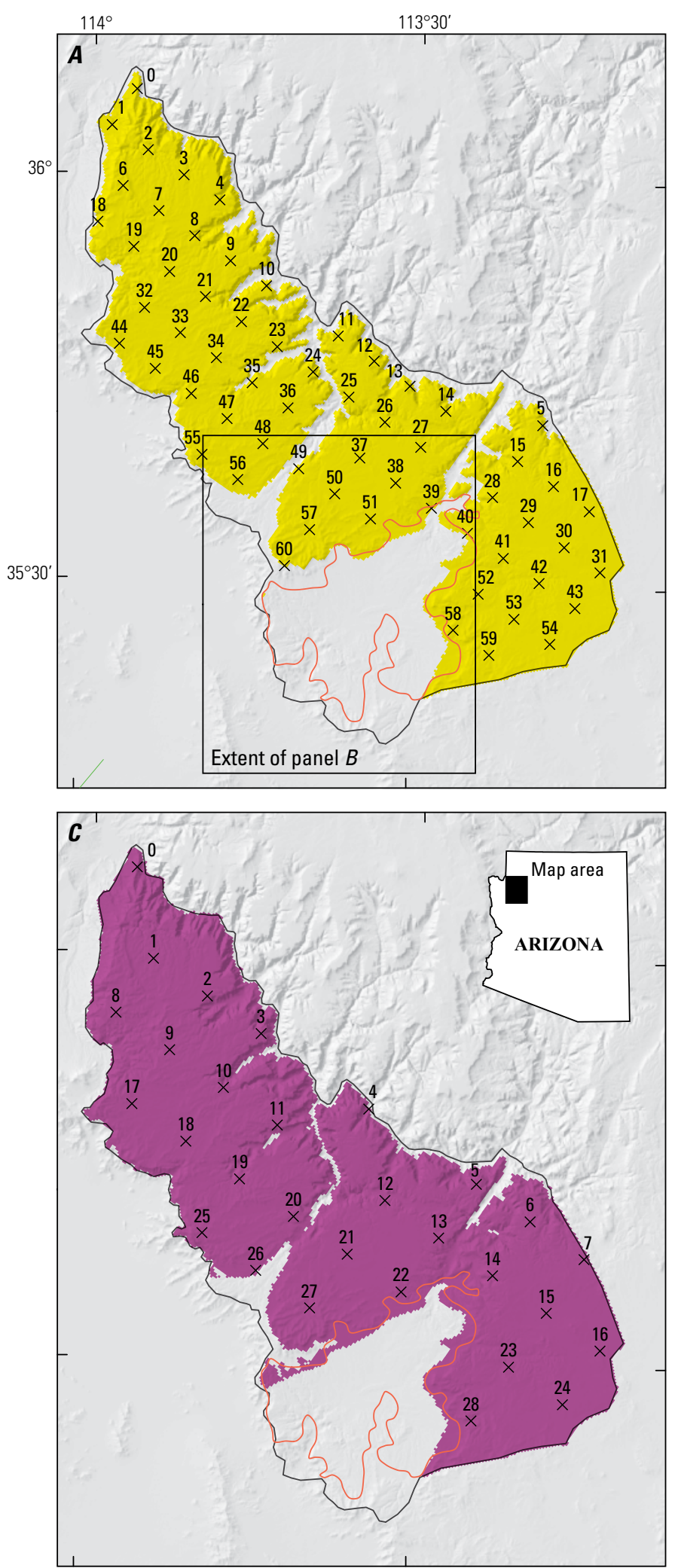

Base from 2012 U.S. Geological Survey 100-meter digital data Universal Transverse Mercator, Zone 12 North

North American Datum of 1983

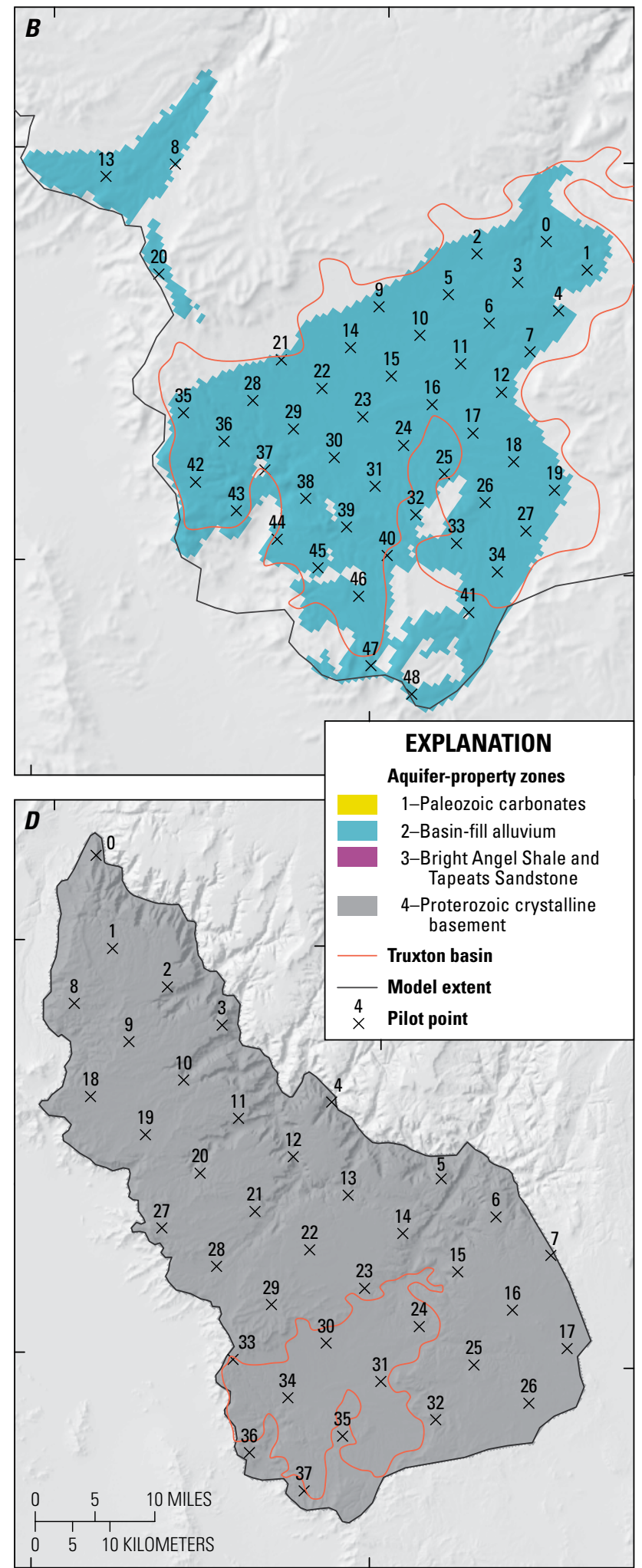

Figure 8. Truxton Basin Hydrologic Model pilot-point distribution by aquifer-property zone for estimation of spatially distributed aquifer property parameters: $(A)$ zone 1, layers 1 and $2 ;(B)$ zone 2, layers 1-3; $(C)$ zone 3, layer $3 ;(D)$ zone 4, layer 4. 
anisotropy is defined in MODFLOW as the ratio of hydraulic conductivity in the row direction over the hydraulic conductivity in the layer (vertical) direction (hk/vk). Vertical anisotropy was fixed to a value of 2.0 in the aquifer-property zones that represent Paleozoic carbonates and basin-fill alluvium, and to a value of 10.0 in the aquifer-property zones that represent the Bright Angel Shale and Proterozoic crystalline basement.

\section{Estimation of Parameters}

Horizontal hydraulic conductivity (figs. 9 and 10) and drain conductance values remained adjustable through the final automated parameter estimation run. Pilot-point estimates of horizontal hydraulic conductivity (hk) in the Bright Angel Shale (aquifer-property zone 3 ) and crystalline basement rock (aquifer-property zone 4) generally fell below the initial estimate of $0.03 \mathrm{ft} / \mathrm{day}$, with several hk values in zone 4 just above the specified lower bound of $0.00328 \mathrm{ft} / \mathrm{day}$. Estimated hk values within the aquifer-property zone that represent basin-fill alluvium (aquifer-property zone 2) remained close to the initial value of $9.8 \mathrm{ft} /$ day, except for lower values estimated around the head of Peach Springs Canyon. In the Paleozoic carbonate rock zone (aquifer-property zone 1), estimated hk ranged between $0.5-3.5 \mathrm{ft} /$ day. The estimated hk values are within one order of magnitude in each zone, a relatively small range.

Drain conductance parameters for each flux-observation zone were adjustable through the final automated calibration run. The initial estimate, as well as upper and lower bounds were periodically adjusted during manual iterations to improve model stability and better match target observations. In the final automated calibration run, all except one of the conductance parameters changed very little from the initial estimate of $10,700 \mathrm{ft}^{2} /$ day. The conductance parameters for flux-observation zones 4 and 8 were just below the initial estimate, but the conductance parameter for zone 9 fell to the lower bound. This was likely a result of the parameter estimation software attempting to limit discharge from the Peach Springs Canyon flux-observation zone. Conductance parameters have little direct physical meaning in most groundwater model applications. Their primary utility is in offsetting artifacts caused by grid discretization (Anderson and others, 2015).

Composite scaled sensitivities are a measure of the amount of information obtained from observations for the estimation of a parameter (Hill and Tiedeman, 2007). Composite scaled sensitivities of parameters can be compared relative to each other to indicate for which parameters the observations provide more information. TBHM parameters composite scaled sensitivities (fig. 11) indicate that the most sensitive calibrated parameters are hydraulic conductivity in the locations of layers 1,2, and 4 near discharge locations adjacent to Truxton basin (fig. 8). Most other parameters allowed to be estimated in the automated calibration process (horizontal hydraulic conductivity in all aquifer-property zones and drain conductance values) are generally insensitive in relation to the weighted observation targets. Parameters representing horizontal and vertical anisotropy were assigned fixed values in earlier iterations of the calibration process owing to insensitivity.

\section{Comparison of Observations and Simulated Equivalents}

Groundwater levels simulated by the calibrated groundwater-flow model at wells and spring sites are comparable to groundwater-level observations and spring site elevations. The spread of residuals is generally in line with the uncertainty of the observations. Comparison of measured and modeled values color coded by hydrostratigraphic unit and sized by target weight (fig. 12) indicate that the largest residuals are associated with groundwater levels in wells at higher elevations. These are the wells presumed to be seated in isolated, perched systems disconnected from regional flow. A cluster of groundwater-level observations and simulated equivalents from wells near the center of Truxton basin do not follow the ideal one-to-one trend (see fig. 12A, line of basin well observations around the 4,000-ft simulated value). Typically, this would indicate that the model is not reproducing the hydraulic gradient of the natural system, but in this case, there is no clear hydraulic gradient to be gleaned from these particular observation data. Rather, observation values appear to vary randomly in space and provide little information about overall gradients, either as a result of measurement error or local interference from small-scale pumping not simulated in the model.

The spatial distribution of head target residuals shows that head targets at higher elevations are generally undersimulated, whereas those at lower elevations are more equally over- and undersimulated (fig. 13). The lower elevation head targets are mostly representative of spring site elevations in the tributary canyons that contain a high degree of uncertainty, both from measurement error and from spring site elevations being an imperfect proxy for groundwater elevation.

Estimated and simulated total discharge in each fluxobservation zone also are comparable (fig. 14). The sum of simulated discharge is higher than the estimated flux target in flux-observation zones 2, 3, 5, 9, and 10, and lower in the remaining zones. These estimates have a high degree of uncertainty and the target fluxes were assigned a correspondingly low weight $(0.002)$. The total simulated discharge in each flux-observation zone is used as a calibration target rather than discharge simulated at specific cells in the proximity of mapped springs. This results in a calibrated model that simulates flow from recharge to discharge areas in general agreement with current understanding of the groundwater system but does not accurately simulate past or current groundwater discharge at known spring locations. 

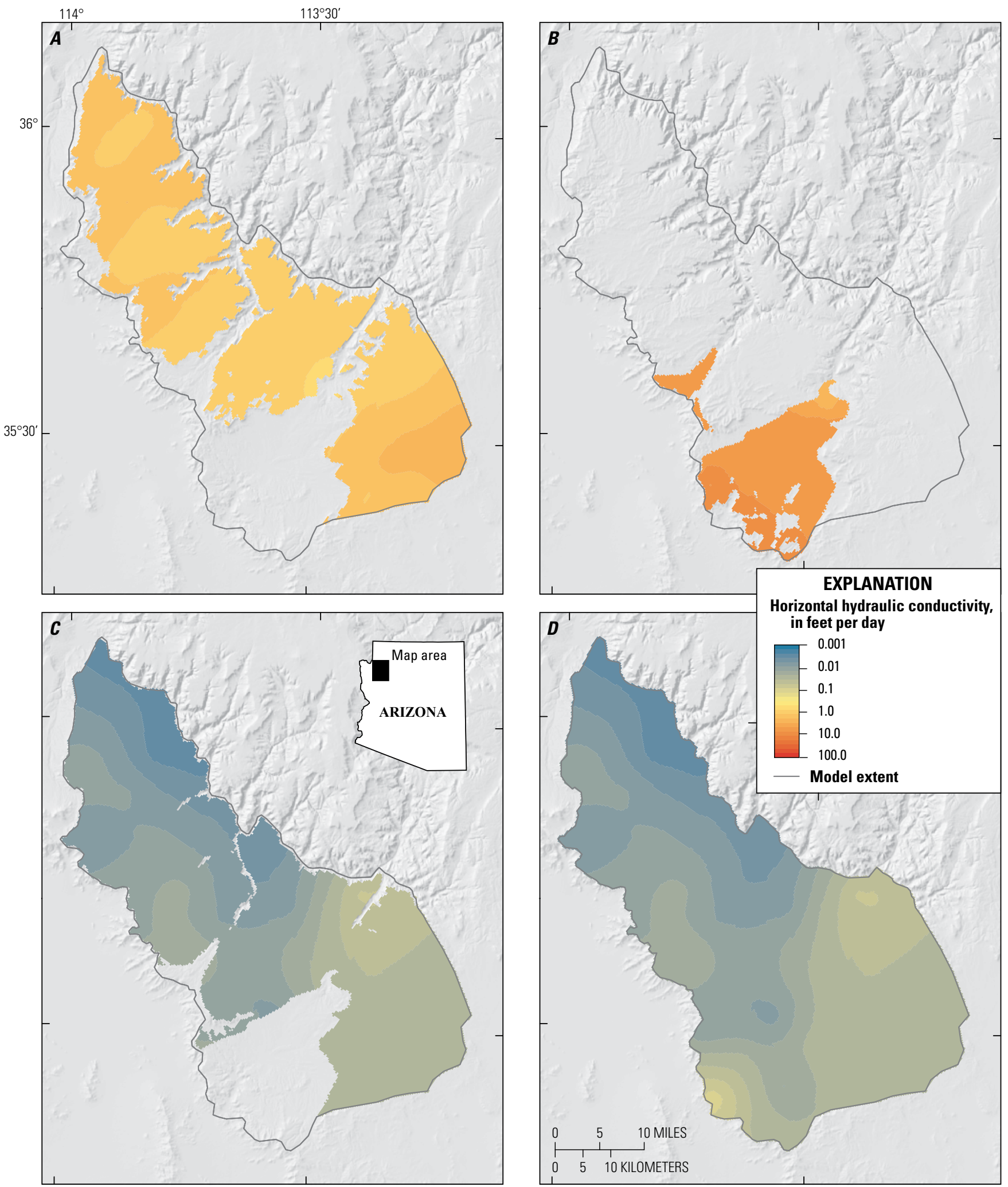

Base from 2012 U S. Geological Survey 100-meter digital dat Universal Transverse Mercator, Zone 12 North

North American Datum of 1983

Figure 9. Calibrated horizontal hydraulic conductivity values in aquifer-property zones $(A) 1,(B) 2,(C) 3$, and $(D) 4$, in feet per day. 
A. Aquifer-property zone 1

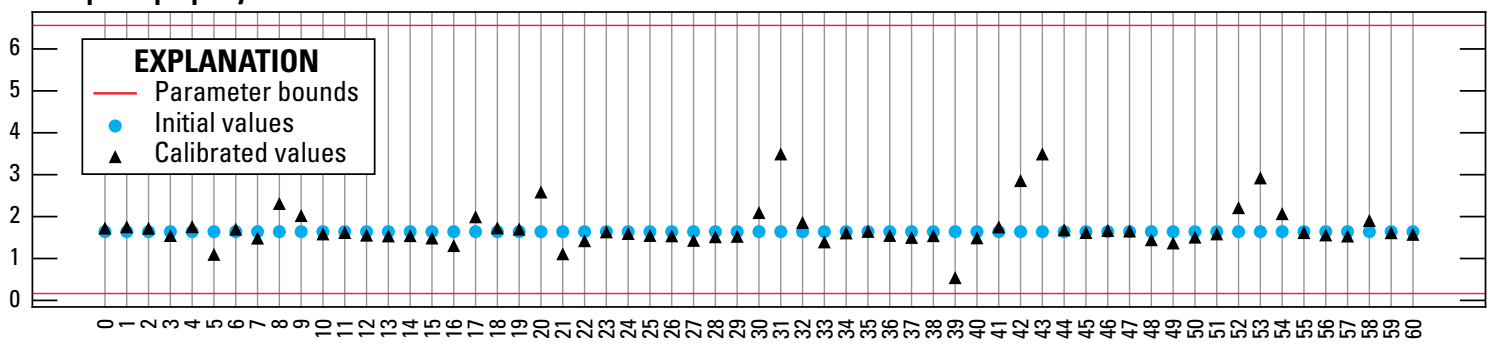

B. Aquifer-property zone 2

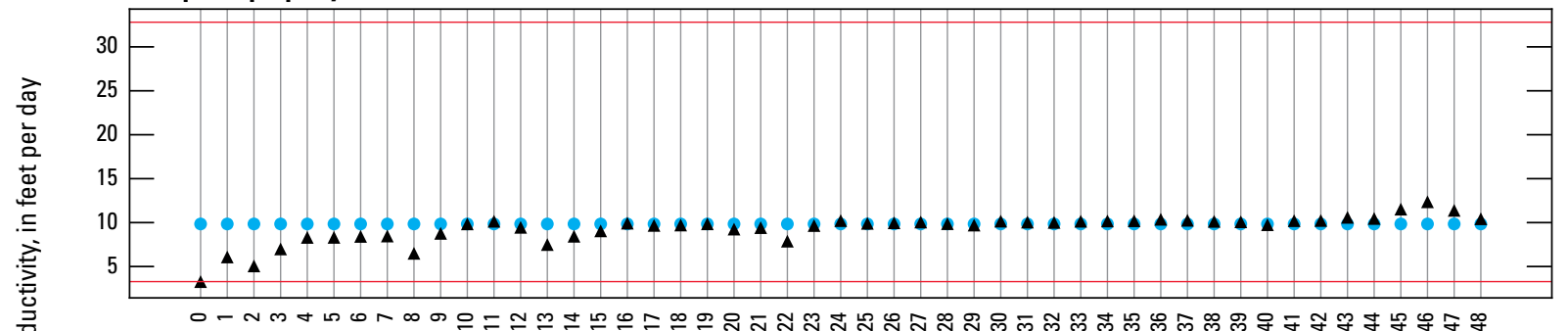

C. Aquifer-property zone 3

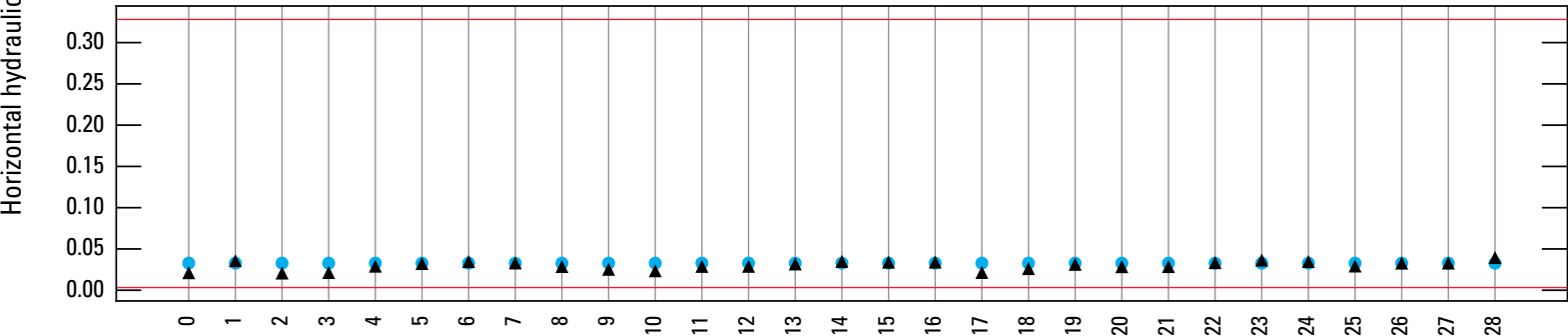

D. Aquifer-property zone 4

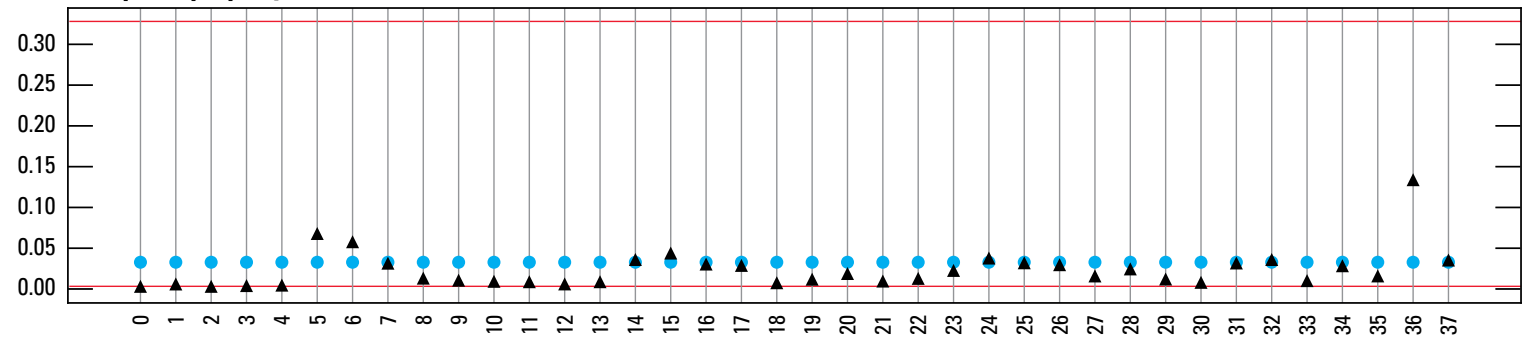

Pilot-point location

E. Flux-observation conductance values

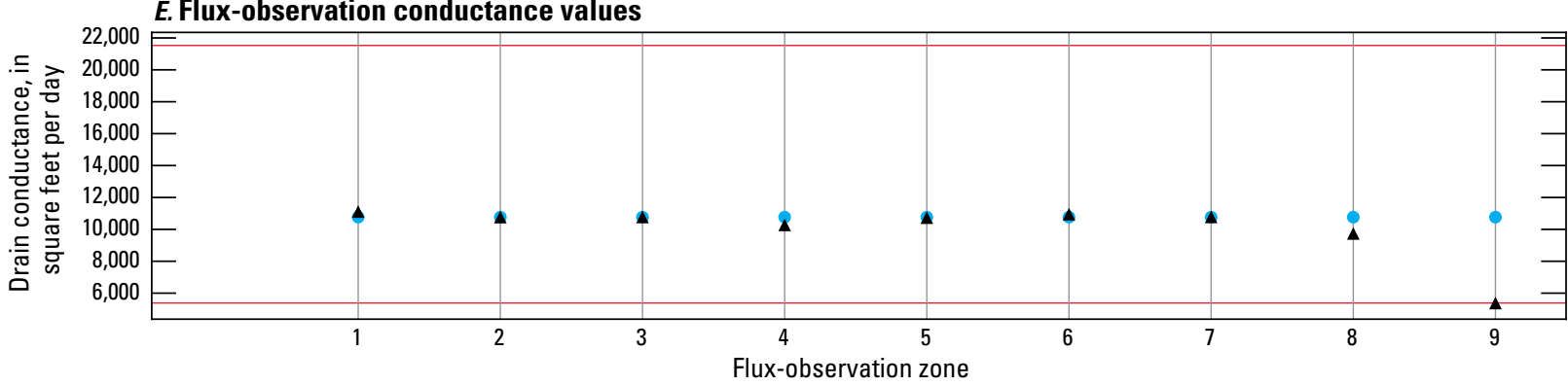

Figure 10. Horizontal hydraulic conductivity (hk) values by aquifer-property zone $(A-D)$, in feet (ft) per day, and flux-observation drain conductance values $(E)$ in $\mathrm{ft}^{2} /$ day. See figure 8 for hk pilot-point locations. 


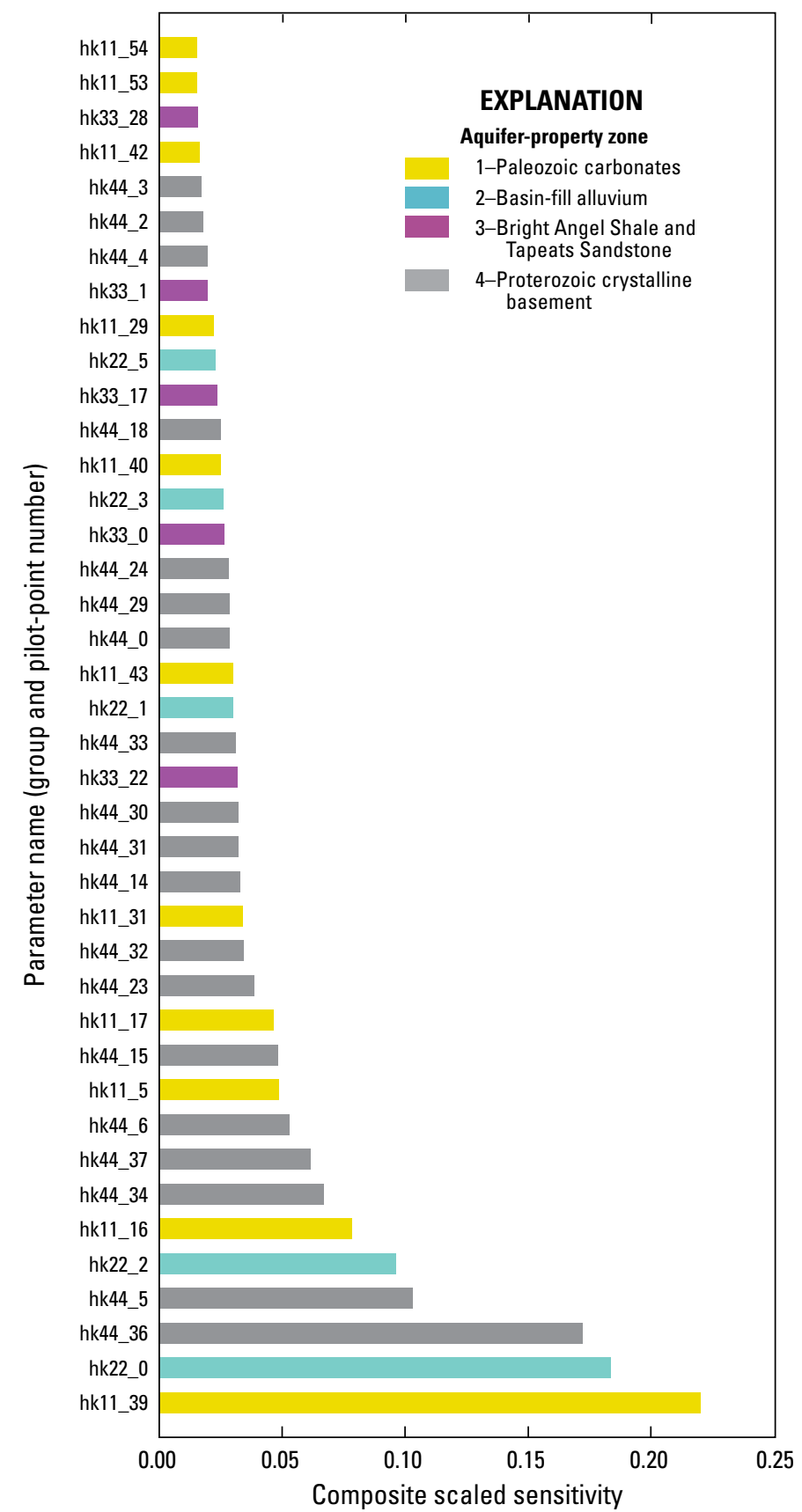

Figure 11. The 40 highest composite-scaled sensitivities of automatically calibrated model parameters in the Truxton Basin Hydrologic Model. Bar colors correspond to aquifer-property zones displayed in figure 8.

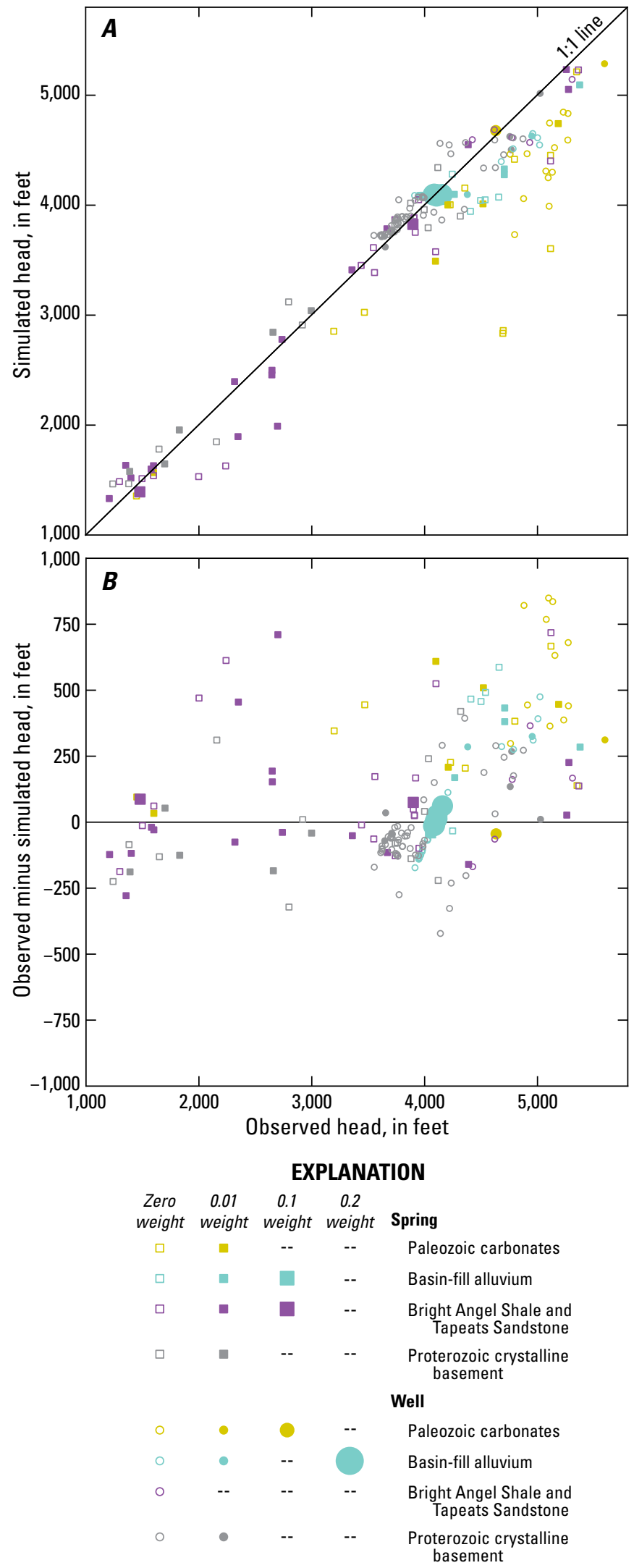

Figure 12. Observed versus simulated heads $(A)$ and observed heads versus model residuals $(B)$, plotted by observation type, aquifer-property zone, and calibration target weight. --, symbol not shown on graph. 


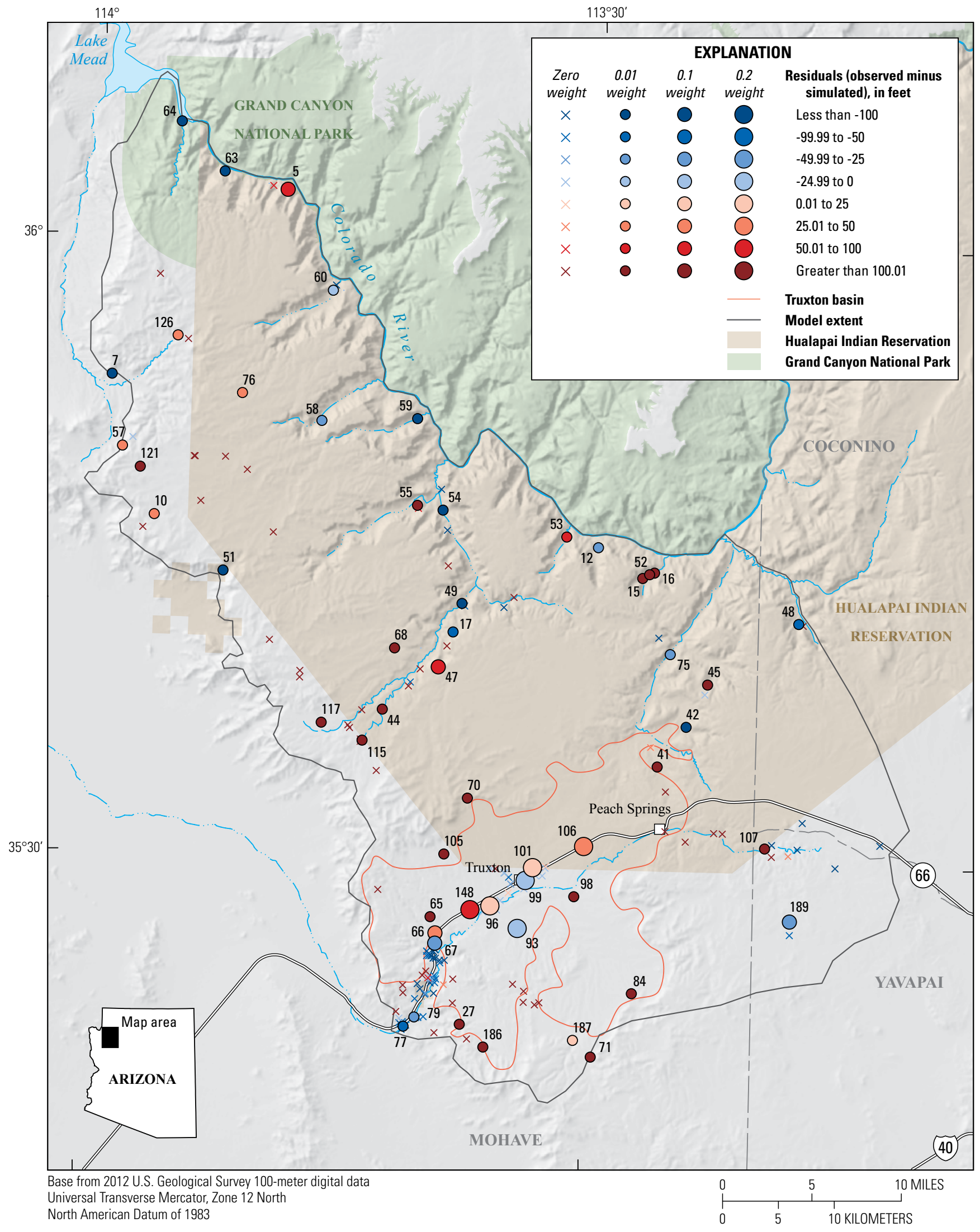

Figure 13. Head target residuals (observed minus simulated), in feet, from the calibrated Truxton Basin Hydrologic Model. The size of marker indicates the relative calibration weight applied $(0.0,0.01,0.1,0.2)$. 


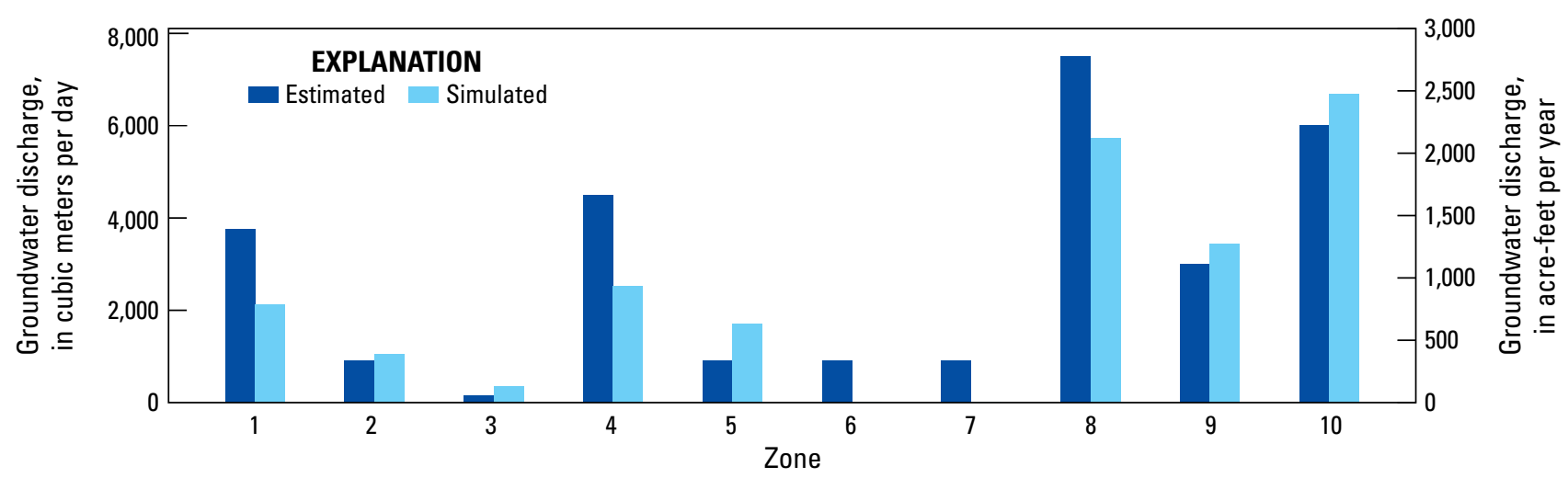

Figure 14. Estimated flux targets and simulated equivalents of total groundwater discharge by flux-observation zone.

The location and magnitude of discharge simulated at the head-dependent flux boundary cells (fig. 15) described in the Groundwater Discharge to Springs and Evapotranspiration section reveal that too much discharge is simulated from the bases of the tributary canyons compared to the exposed outcrops of the Rampart Cave Member of the Muav Limestone around the lower walls of the canyons. This is likely caused by the decision not to attempt explicit simulation of dissolution-enhanced conduit flow. The Muav Limestone is essentially impermeable where unfractured, and all major springs of the plateau discharge groundwater transmitted along a network of dissolution-enhanced fractures and joints. By simulating the Paleozoic carbonate rocks as an equivalent porous medium, groundwater flow is spread across the model layer rather than focused in narrow pathways toward spring locations in the canyons. This choice allows more downward percolation to be simulated to the shale and crystalline basement layers than would be if all but the fractured parts of the carbonate rock were simulated to be much less conductive. This aspect of the TBHM was deemed tolerable because the model objectives are focused within the Truxton basin.

Simulated head contours and groundwater flow directions are generally in agreement with the conceptual model (fig. 16). Head gradients on the western Hualapai Plateau are steep and align with the regional dip of the strata to the northeast. Gradients on the eastern Hualapai Plateau are less steep and not related to strata dip direction. Simulated flow from recharge areas at the southern margin of the model sweeps to the east and north toward discharge locations in Diamond Creek. There is a near-zero gradient of simulated heads in the majority of Truxton basin except where groundwater discharges to Truxton Wash on the southwest end, and where water exits the basin as underflow on the northeast end.

\section{Forecasting Simulations and Uncertainty Analysis}

The calibrated TBHM is used to forecast potential changes in groundwater levels based on projected future groundwater withdrawals in the basin. The Bureau of Reclamation provided three future scenarios of groundwater withdrawals in Truxton basin. All scenarios run from 2020 until 2140 and include step increases in the pumping rate, which occur in 20-year intervals (table 2; fig. 17). Withdrawals from the proposed new well (GW004) are identical in all scenarios. Withdrawals from the existing Truxton well field increase at different rates in each scenario based on low, medium, and high projections of population growth and water needs. All three scenarios assume no additional pumping is occurring elsewhere in the Truxton aquifer during the time of the simulations.

A transient forecast model was built by extending the simulation time of the calibrated steady-state model. Five stress periods were added to simulate transient conditions including estimated withdrawals from the Truxton well field between 1976-2019. Seven additional stress periods simulate future conditions associated with withdrawals specified in the scenarios of interest. Estimates of aquifer storage properties were assigned as uniform values within each aquifer-property zone (table 6). All other parameters are identical to the final calibrated values of the steady-state model.

Drawdown forecasts are calculated as the difference in simulated hydraulic heads in a future year compared to simulated hydraulic heads at the beginning of the year 2020, before the onset of hypothetical pumping scenarios. The transient forecast model derived from the calibrated TBHM was used to produce a snapshot of forecasted drawdowns at the beginning of years 2070 and 2140 for the low, medium, and high pumping scenarios (fig. 18). These results present one realization of potential future conditions per pumping scenario and are based on the optimal set of model parameters selected through the manual and automated parameter estimation process described above.

To address the effects of uncertainty in aquifer properties on aquifer response to withdrawals, the forecasts of groundwaterlevel changes are also presented as a range of probable outcomes that result from the withdrawal scenarios. These outcomes are produced using a Monte Carlo approach wherein an ensemble of models is run using parameter values drawn from within a range of hydrologically reasonable values. Hydraulic conductivity values are drawn from a distribution based on the identifiability of each parameter determined in the calibration process. Storage property values, which were not estimated by parameter estimation, are drawn from a normal distribution built using the initial estimate 


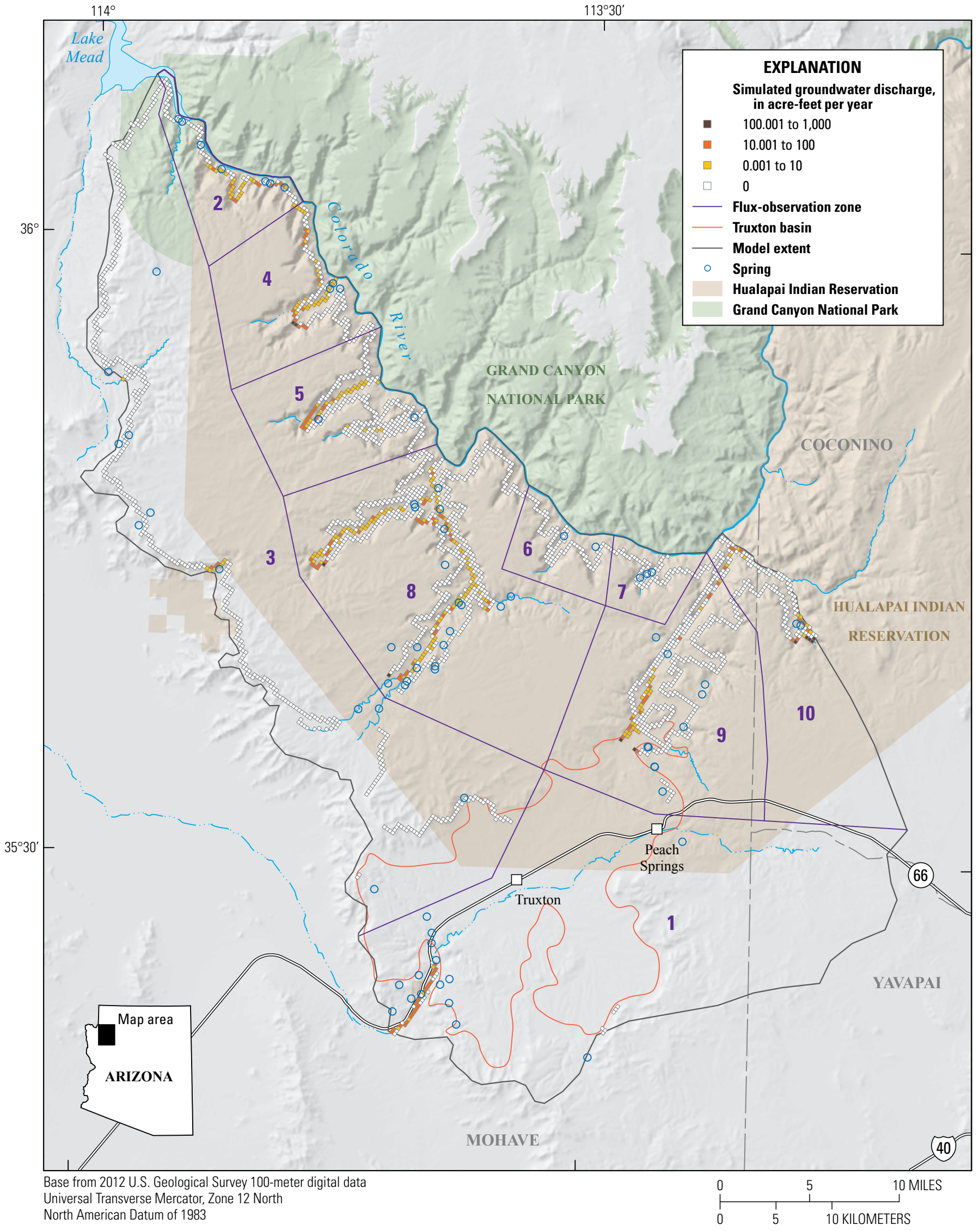

Figure 15. Simulated groundwater discharge at head-dependent flux model cells. 


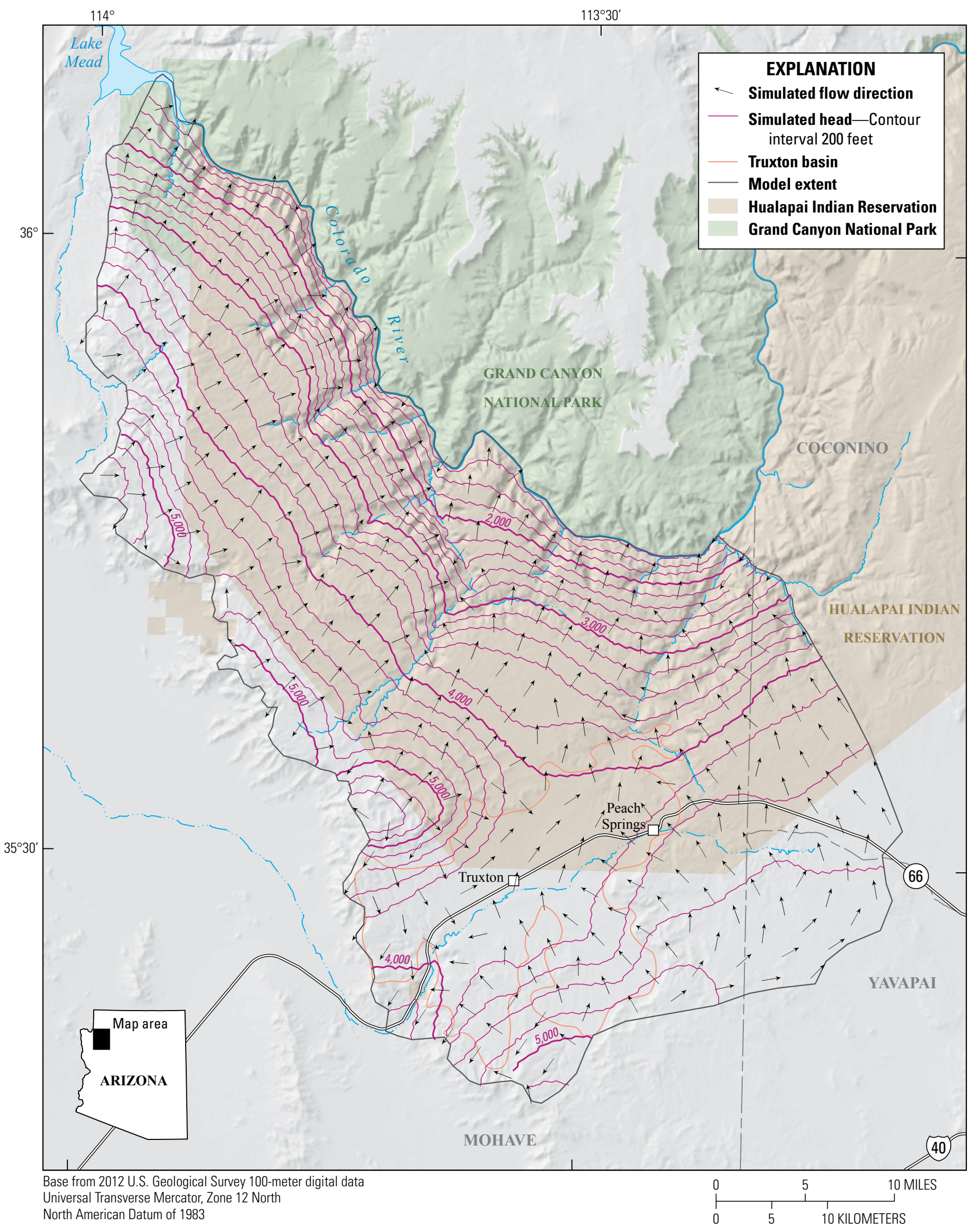

Figure 16. Truxton Basin Hydrologic Model simulated head contours and flow directions. 
A. Scenario pumping locations

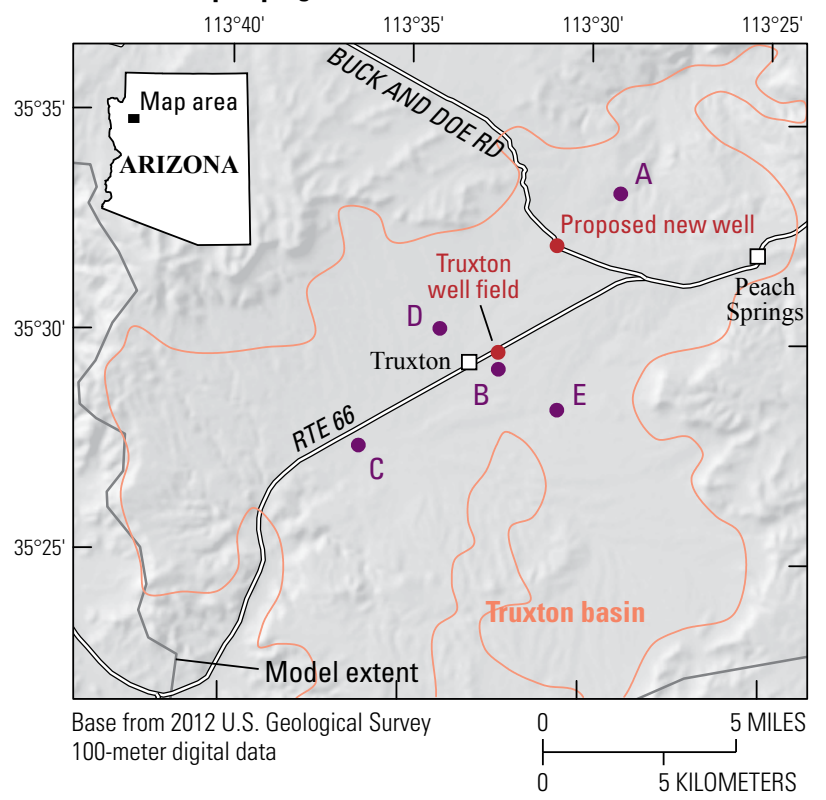

B. Simulated pumping rates

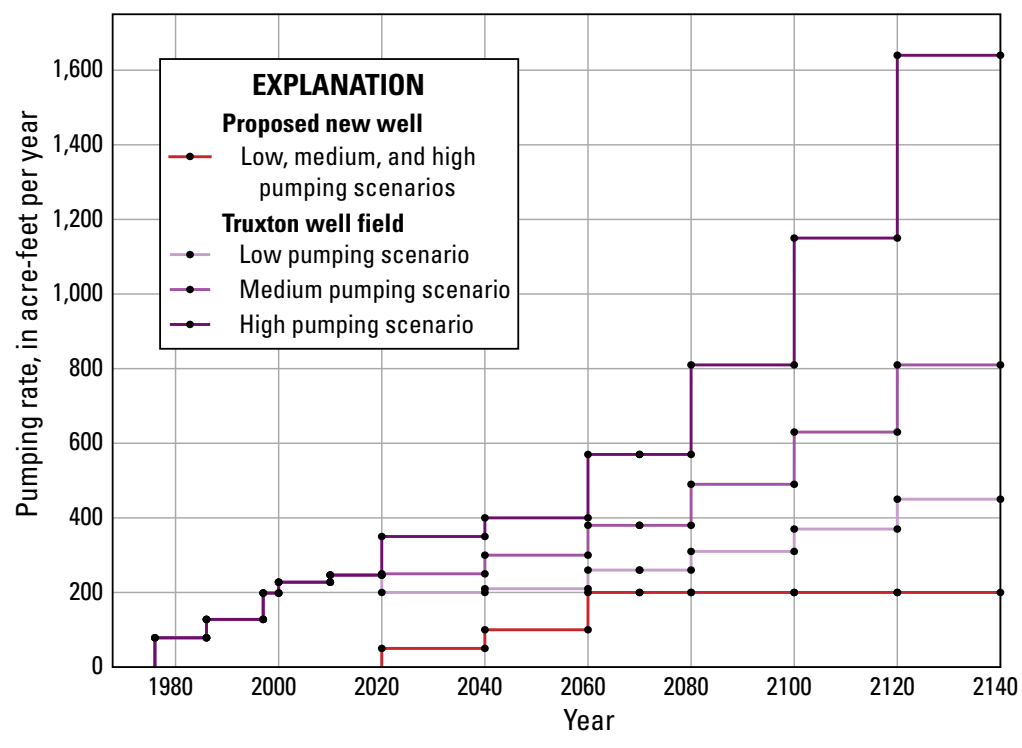

Figure 17. Truxton Basin Hydrologic Model forecasting simulation, including $(A)$ scenario pumping locations and forecast locations, and $(B)$ simulated rates of withdrawal, in acre-feet per year. Dots indicate the beginning and end of simulation stress periods.
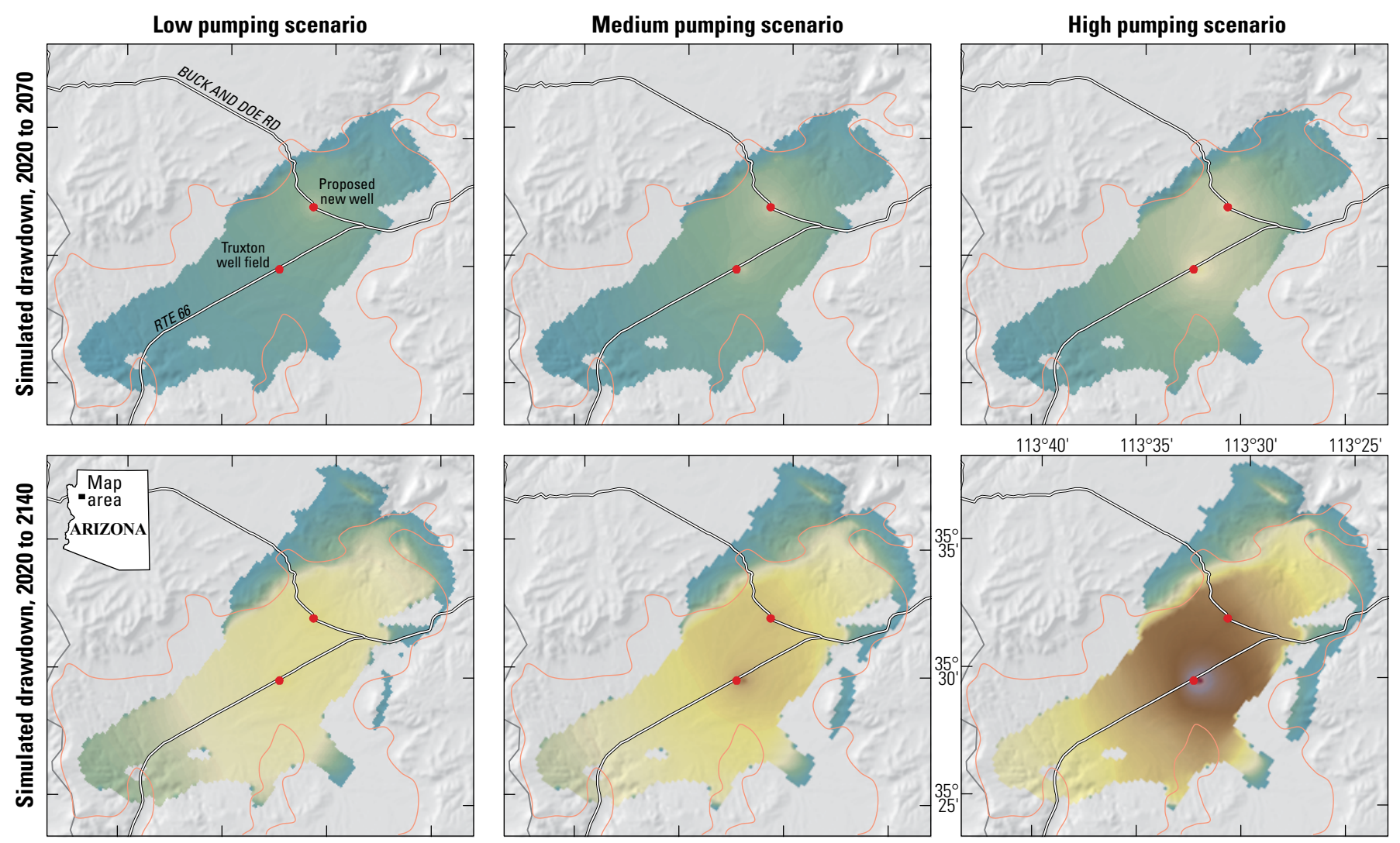

Base from 2012 U.S. Geological Survey 100-meter digital data Universal Transverse Mercator, Zone 12 North North American Datum of 1983

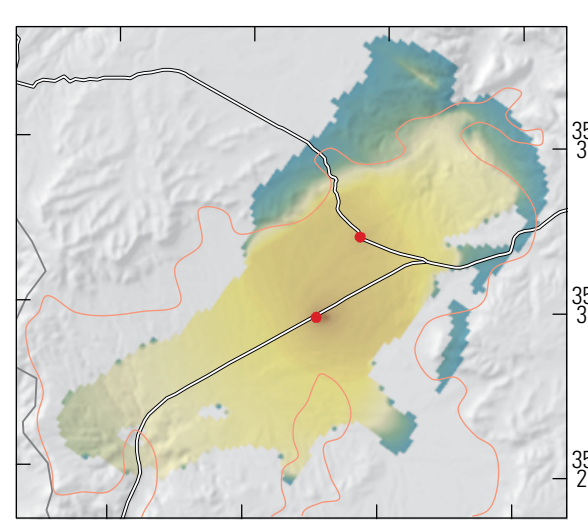

EXPLANATION

Simulated drawdown, in feet \begin{tabular}{|lllll}
\hline 1 & 10 & 20 & 30 & 40
\end{tabular} - Model extent

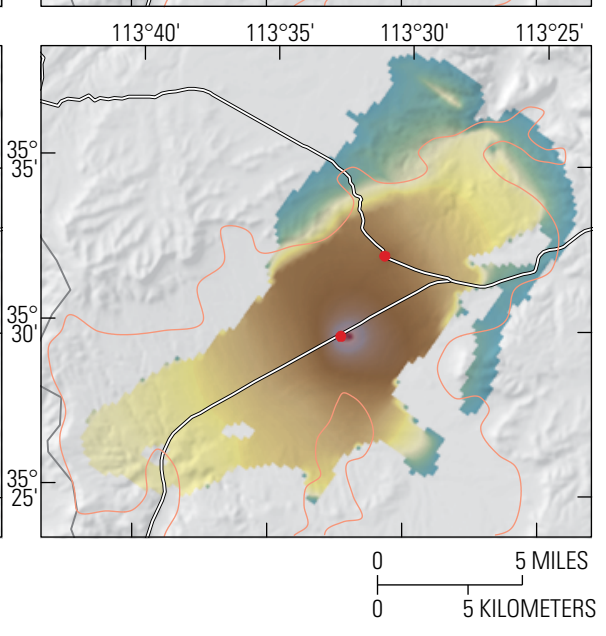

Figure 18. Simulated drawdown at year 2070 and year 2140 from simulated year 2020 levels for low, medium, and high pumping scenarios using the primary bedrock altitude model. 
as the mean, and the estimated lower and upper bounds as \pm 3 standard deviations. Future recharge rate was likewise varied by drawing a multiplying factor from a distribution between 0.75 and 1.25. Multiplying factors of the same range were also implemented for all spatially distributed, aquifer-property parameters in the Monte Carlo ensembles.

All pilot-point parameters within the aquifer-property zone that represent Truxton basin and horizontal hydraulic conductivity in all aquifer-property zones were made adjustable in the Monte Carlo runs (table 8). The remaining pilot-point parameters outside of the basin that represent specific yield, specific storage, and vertical anisotropy were fixed to their precalibration initial estimate, but were uniformly increased or decreased within each aquifer parameter group in each Monte Carlo run by the relevant multiplying factor (table 9). Drain conductance and horizontal anisotropy parameters were fixed to precalibration initial estimates. Adjustable parameter values and group multiplying factors were randomly drawn from their calculated or prescribed distributions to create an ensemble of 10,000 unique models.

The contribution of uncertainty in the geophysical interpretations of basin depth to forecast uncertainty was evaluated by building two additional ensembles in which the contained models are identical to the models of the original ensemble except for the simulated bedrock altitudes that underlie Truxton basin. These ensembles use the high and low plausible bedrock altitudes beneath the basin according to the uncertainty of the geophysical interpretations presented alongside the primary bedrock altitude in Ball (2020).

The three ensembles of models that represent three plausible estimates of bedrock altitudes within Truxton basin were each run three times to simulate low, medium, and high future pumping scenarios. Thus, a total of nine separate forecasts of groundwater levels were produced, one for each combination of basin bedrock altitude and future pumping scenario. Each forecast is the result of applying the combination of pumping scenario and bedrock altitude to the base ensemble of 10,000 model parameter sets described above. Model results were filtered to remove failed runs and reject model runs that resulted in measurement objective functions greater than 150 percent of the calibrated model (table 10).

Forecasted groundwater levels were tracked at locations throughout Truxton basin spaced 10 model cells (approximately $2 \mathrm{mi}$ ) apart in row and column direction. Simulated drawdowns at these locations were calculated as the difference in simulated groundwater levels between the years 2020-2070 and 2020-2140. This report discusses a representative subset of these locations.

The largest simulated drawdowns of groundwater levels (fig. 19) occur at location B, the forecast location closest to the Truxton well field, where most of the simulated future pumping occurs (fig. 17). These ensemble simulations produce a range of drawdowns under the projected future high pumping scenario of between 20 and $39 \mathrm{ft}$ at location $\mathrm{B}$, with a median drawdown of $28 \mathrm{ft}$ (figs. 18, 19; table 2.2). The low pumping scenario produces a range of drawdowns between 5 and $15 \mathrm{ft}$ and a median drawdown of $10 \mathrm{ft}$ at the same location over the same period of time. Simulated drawdown decreases away from the pumping locations toward the basin margins. The smallest drawdowns occur in the southwestern extent of the basin.

The model ensembles that use the lower plausible bedrock elevations and greater saturated thickness (Ball, 2020, her fig. 8) generally produce smaller forecasted drawdowns at the selected locations (fig. 19) than those produced by the primary and high bedrock elevation models (fig. 20). This could be an effect of simulating higher transmissivities caused by increasing the saturated thickness of the aquifer, which spreads the removal of water from storage over a larger areas and results in a smaller amount of drawdown at a given location. However, the opposite shift to larger drawdowns in the vicinity of the pumping wells is not as apparent in the forecasts of the higher bedrock elevation ensemble of models, which would be expected from simulating lower transmissivities. This is because depths to basement in the high bedrock elevation model and the primary bedrock elevation model are essentially the same except in the northwestern extent of the basin (Ball, 2020, her figs. 7 and 8).

\section{Discussion and Model Limitations}

Forecast uncertainty is derived from many sources that can generally be classified into measurement error and structural error. Measurement error causes the uncertainty associated with the observations used as calibration targets. This uncertainty cascades to the model parameters in the calibration process, as different sets of parameter values can produce simulated equivalents within the bounds of the uncertainty of the observations used as calibration targets. Commonly, some parameters are essentially uninformed by the available observation data and must rely on best estimates. Lack of data required estimates to be made of aquifer storage properties that are important to forecasting groundwater-level changes. Appropriately large bounds were placed around these initial aquifer property parameter estimates to develop a range of likely forecast outcomes.

Structural error arises from simplifications and assumptions implemented in the model design. Although subjective, these choices are necessary to create a numerical simulation of a complex natural system. The main sources of structural error in this model are the rate and distribution of simulated groundwater recharge, the allowance of discharge to occur anywhere the Rampart Cave Member crops out, and the location and use of zero-flux boundary conditions to represent presumed hydraulic barriers on the south and east sides of the model.

The spatial distribution of long-term average recharge was determined in the development of the groundwater budget and only manually adjusted during early iterations of the calibration process. Hydraulic conductivity parameters continued to be automatically estimated in the later iterations, making their calibrated values conditional on the chosen recharge distribution. The use of a global multiplier to adjust the rate of future recharge is a simple modification of an already simplified representation based on long-term average precipitation. Correlations are very strong between the future recharge multiplier parameter and the forecasted groundwater-level changes in Truxton basin (fig. 21). 
Table 8. Initial value and range for adjustable aquifer property parameters in forecast Monte Carlo simulations.

[ft, feet]

\begin{tabular}{lllll}
\hline \multicolumn{1}{c}{ Aquifer property parameter } & \multicolumn{1}{c}{ Aquifer-property zone } & $\begin{array}{c}\text { Initial } \\
\text { value }\end{array}$ & $\begin{array}{c}\text { Lower } \\
\text { bound }\end{array}$ & $\begin{array}{c}\text { Upper } \\
\text { bound }\end{array}$ \\
\hline $\begin{array}{l}\text { Horizontal hydraulic } \\
\text { conductivity (ft/day) }\end{array}$ & $\begin{array}{c}\text { (1) Undivided lower } \\
\text { Paleozoic carbonates }\end{array}$ & Variable & 0.17 & 6.5 \\
& (2) Basin fill & Variable & 3.3 & 33.0 \\
& (3) Bright Angel Shale & Variable & 0.003 & 0.3 \\
& (4) Proterozoic basement & Variable & 0.003 & 0.3 \\
\hline Vertical anisotropy & (2) Basin fill & 2.0 & 1.0 & 10.0 \\
\hline Specific yield & (2) Basin fill & 0.10 & 0.05 & 0.25 \\
\hline Specific storage $\left(\mathrm{ft}^{-1}\right)$ & (2) Basin fill & $6.0 \mathrm{E}^{-05}$ & $3.0 \mathrm{E}^{-06}$ & $1.5 \mathrm{E}^{-04}$ \\
\hline
\end{tabular}

Table 9. Multiplying factors used in forecast Monte Carlo simulations. Factors are applied independently to each aquifer-property zone, except for the future recharge multiplier, which applies to the entire model grid.

\begin{tabular}{lccc}
\hline \multicolumn{1}{c}{ Parameter multiplier } & $\begin{array}{c}\text { Initial } \\
\text { value }\end{array}$ & $\begin{array}{c}\text { Lower } \\
\text { bound }\end{array}$ & $\begin{array}{c}\text { Upper } \\
\text { bound }\end{array}$ \\
\hline Horizontal hydraulic conductivity & 1.0 & 0.75 & 1.25 \\
Vertical anisotropy & 1.0 & 0.75 & 1.25 \\
Specific yield & 1.0 & 0.75 & 1.25 \\
Specific storage & 1.0 & 0.75 & 1.25 \\
Future recharge multiplying factor & 1.0 & 0.75 & 1.25 \\
\hline
\end{tabular}

Table 10. Summary of failed, rejected, and accepted Monte Carlo model runs.

\begin{tabular}{llcccc}
\hline Pumping scenario & $\begin{array}{c}\text { Bedrock } \\
\text { altitude }\end{array}$ & Total runs & $\begin{array}{c}\text { Failed model } \\
\text { runs }\end{array}$ & $\begin{array}{c}\text { Rejected } \\
\text { model runs }\end{array}$ & $\begin{array}{c}\text { Accepted } \\
\text { model runs }\end{array}$ \\
\hline Low & Primary & 10,000 & 27 & 336 & 9,637 \\
& Low & 10,000 & 18 & 729 & 9,253 \\
\multirow{2}{*}{ Medium } & High & 10,000 & 16 & 3,709 & 6,275 \\
& Primary & 10,000 & 20 & 337 & 9,643 \\
& Low & 10,000 & 15 & 731 & 9,254 \\
High & High & 10,000 & 20 & 3,707 & 6,273 \\
& Primary & 10,000 & 20 & 334 & 9,646 \\
& Low & 10,000 & 18 & 729 & 9,253 \\
& High & 10,000 & 24 & 3,706 & 6,270 \\
\hline
\end{tabular}



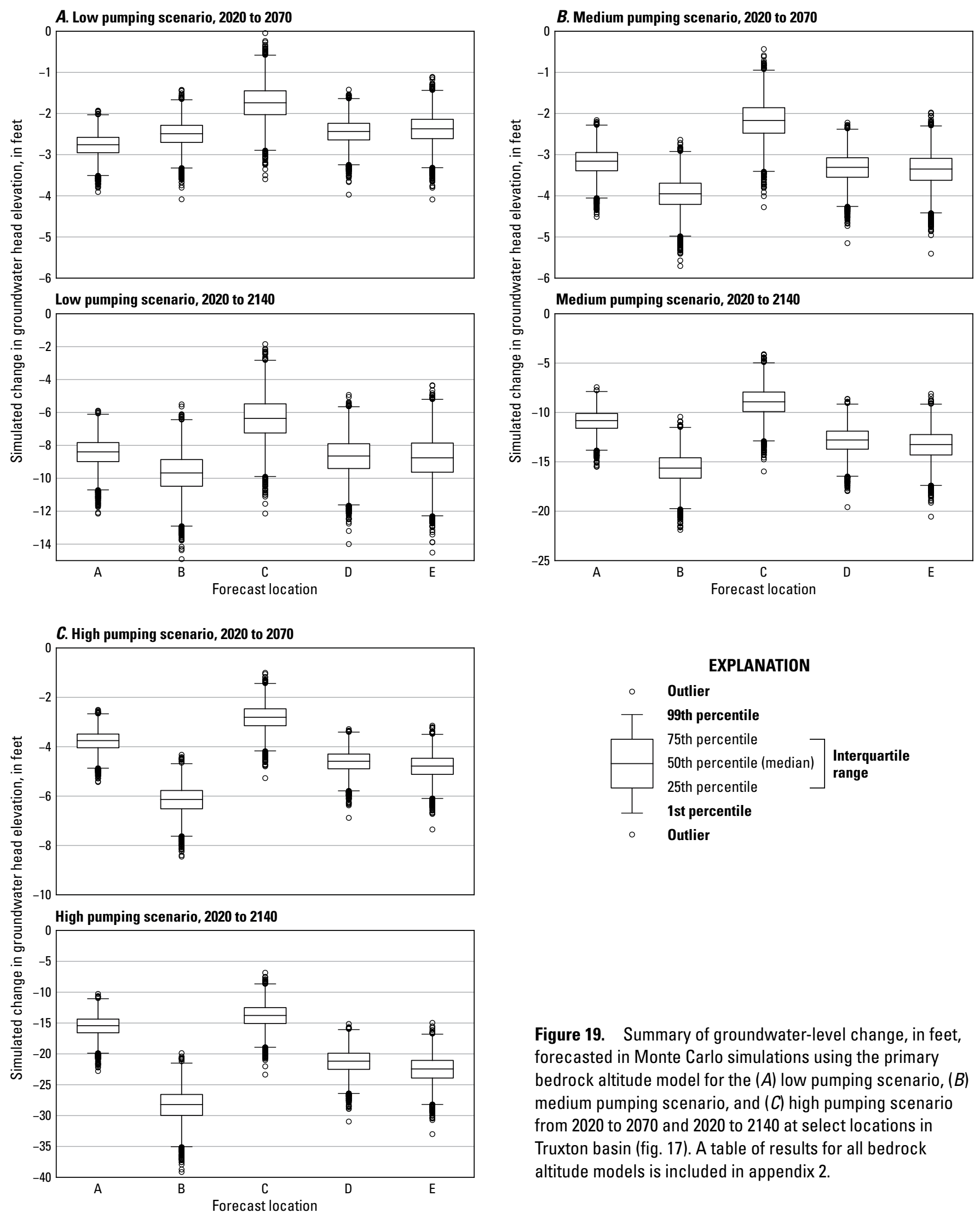

Figure 19. Summary of groundwater-level change, in feet, forecasted in Monte Carlo simulations using the primary bedrock altitude model for the $(A)$ low pumping scenario, $(B)$ medium pumping scenario, and $(C)$ high pumping scenario from 2020 to 2070 and 2020 to 2140 at select locations in Truxton basin (fig. 17). A table of results for all bedrock altitude models is included in appendix 2. 
A. Low pumping scenario groundwater-level change
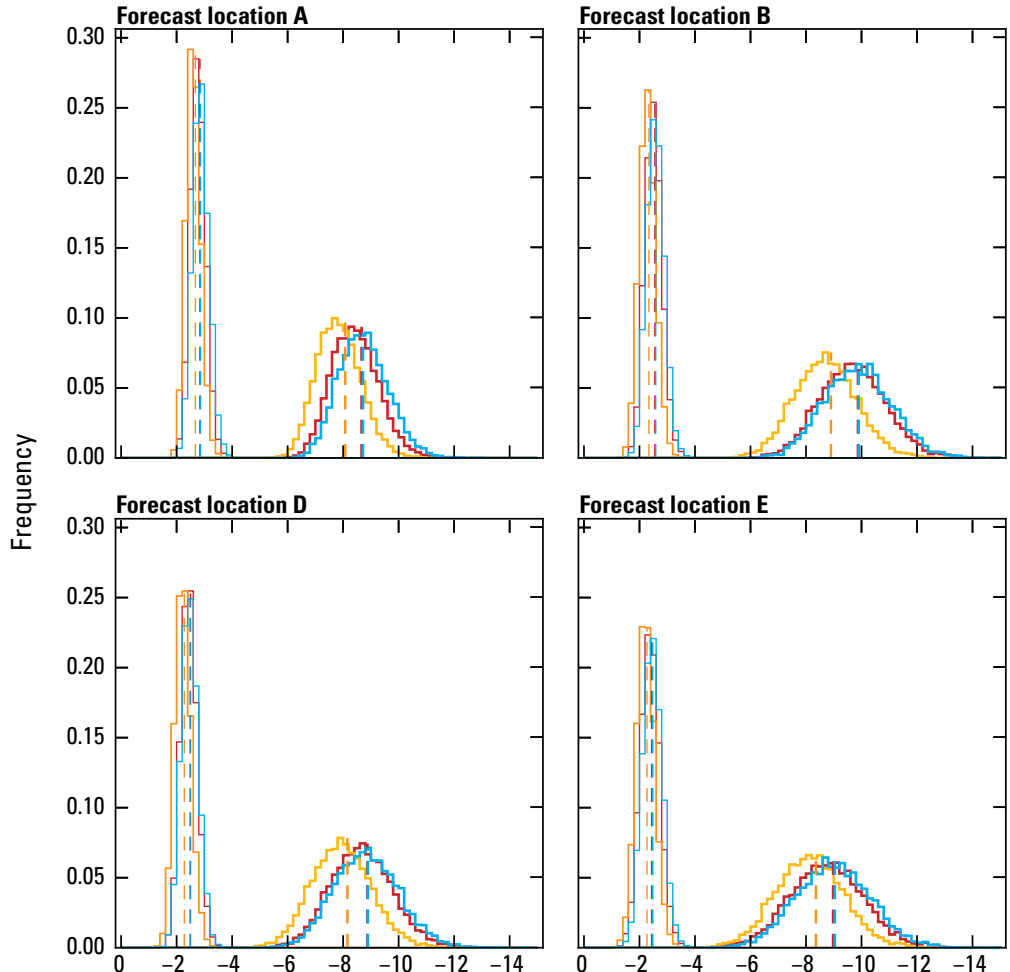

Forecast location E

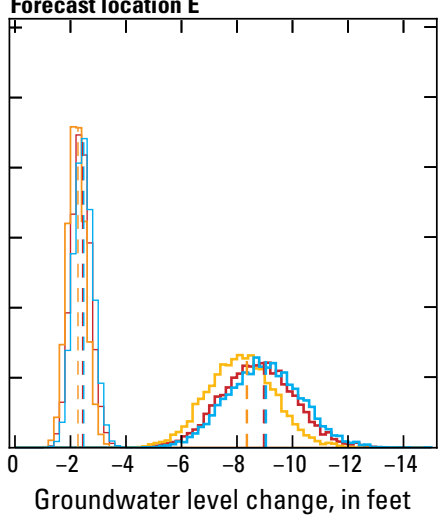

Forecast location $\mathrm{C}$

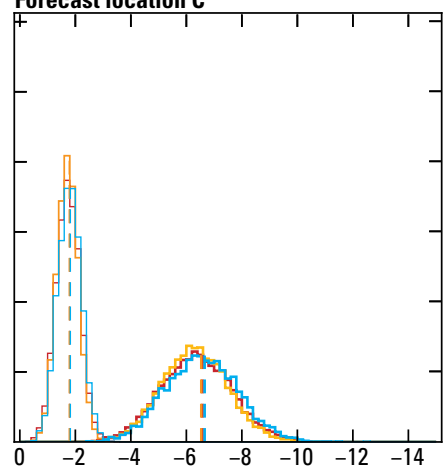

EXPLANATION

\section{Monte}

Carlo Calibrated

2020 to 2070

Primary bedrock altitude Low bedrock altitude High bedrock altitude

2020 to 2140

Primary bedrock altitude Low bedrock altitude High bedrock altitude

\section{B. Medium pumping scenario groundwater-level change}

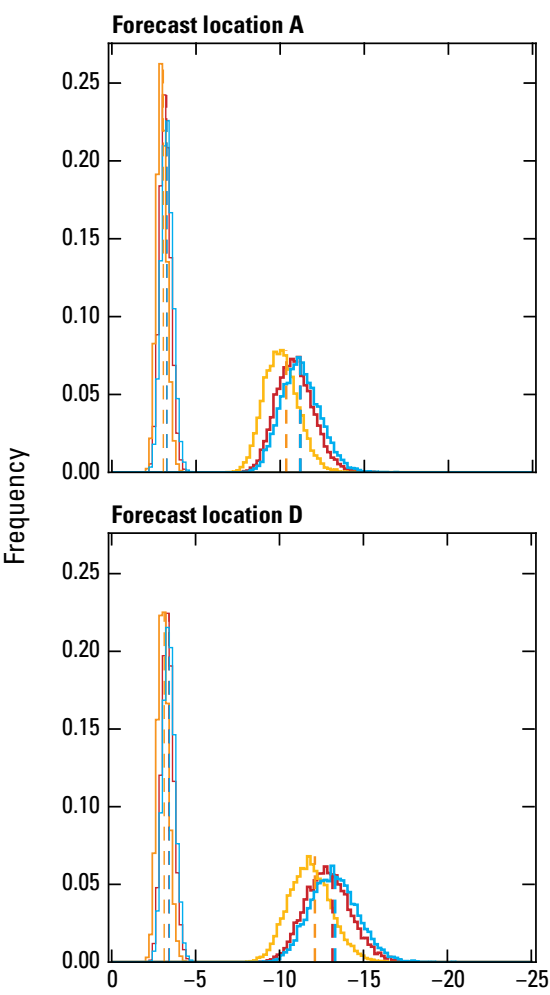

Forecast location B

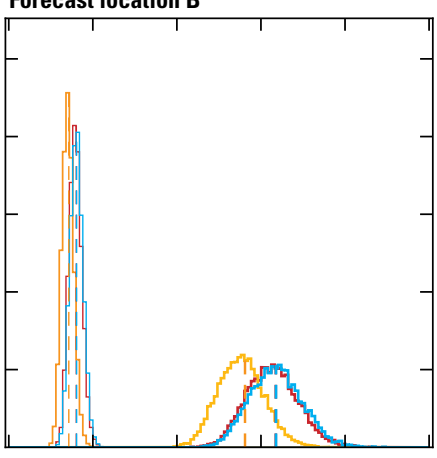

Forecast location $\mathrm{E}$

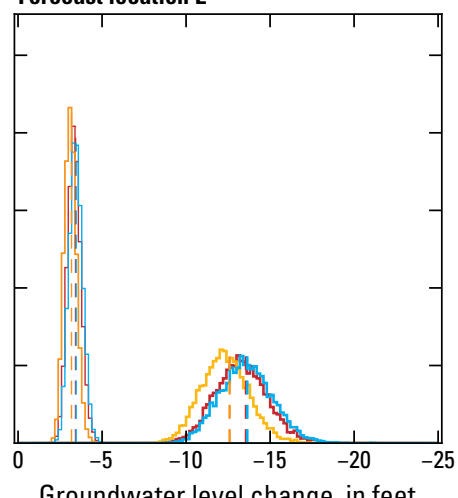

Forecast location C

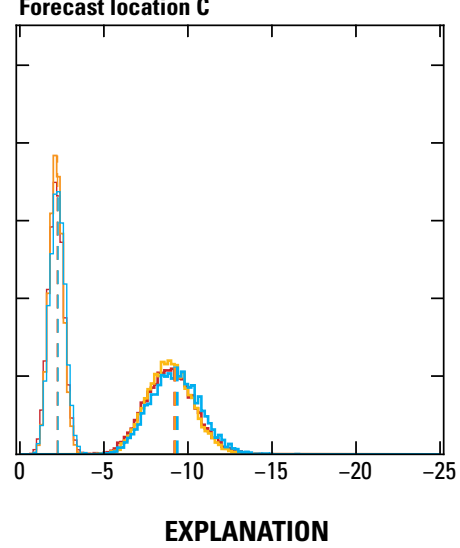

Monte

Calibrated

2020 to 2070

Primary bedrock altitude

Low bedrock altitude

High bedrock altitude

2020 to 2140

Primary bedrock altitude

Low bedrock altitude

High bedrock altitude

Figure 20. Frequency of forecasted groundwater-level changes at select locations in the Truxton basin, 2020 to 2070 and 2020 to 2140, from Monte Carlo model ensembles that represent the $(A)$ low pumping scenario, $(B)$ medium pumping scenario, and $(C)$ high pumping scenario with primary, high, and low basin bedrock altitudes (Ball, 2020). 


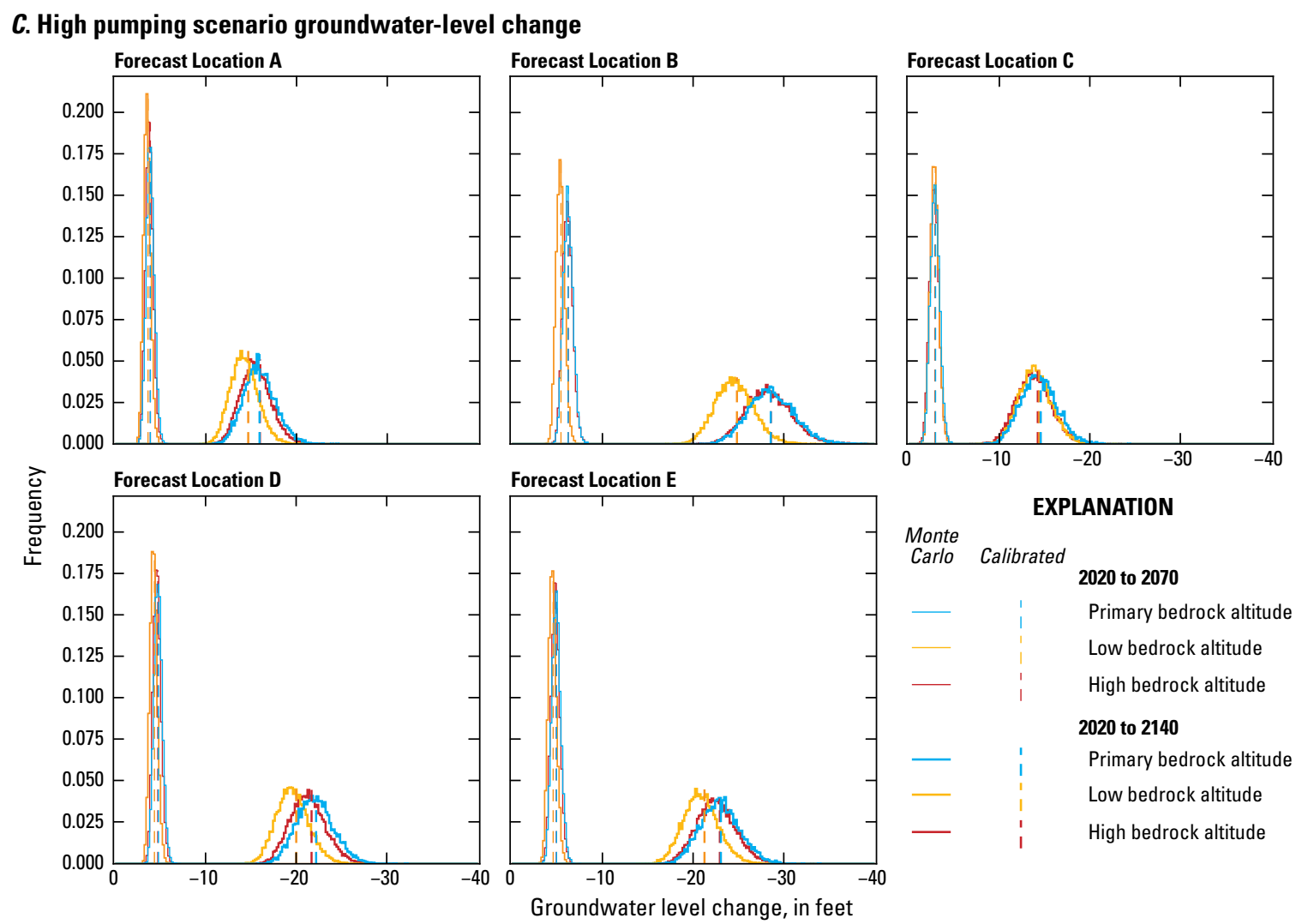

Figure 20.-Continued

More complex conceptions of historical and future recharge uncertainty might produce groundwater-level forecasts that are less directly correlated to a single model parameter. In this case, transient head and flux-observation data were deemed inadequate to justify more complex representations.

Inadequate characterization of the rates and temporal variability of groundwater discharge from springs and evapotranspiration prompted the simplification of how these processes are simulated in the model. Rather than explicitly simulating springs at single cell locations and making a host of assumptions necessary to implement a separate simulation of evapotranspiration, a head-dependent flux boundary condition was created along the base of the exposed Rampart Cave Member and along stream channels in the center of the tributary canyons. This allows the total simulated discharge in each tributary canyon to be matched to target estimations but does not distinguish between the type or location of the simulated discharge within each flux-observation zone. This lack of resolution within zones is likely inconsequential to the modeling objectives in all zones except flux-observation zone 9, which covers Peach Springs Canyon, where too much discharge is simulated in the upper reaches of the canyon.

The zero-flux boundary condition on the eastern extent of the model represents a presumed physical barrier imposed by Blue Mountain Fault and (or) a hydraulic barrier imposed by a streamline toward discharge that occurs in Blue Mountain Canyon and Diamond Canyon. Groundwater flow clearly does not cross the strike of these canyons where the aquifer is bisected, but there could be flow across the southeastern segment of this boundary condition where the aquifer units are continuous. In such a case, flow would continue northnortheast parallel to the Toroweap Fault toward springs in the Grand Canyon.

Propagation of drawdown is dependent on aquifer diffusivity (transmissivity divided by storativity) and proximity to sources of capture (Barlow and Leake, 2012). Almost all simulated discharge to wells in the future pumping scenarios is balanced by a simulated reduction in storage (storage-dominated supply) and not by a reduction of simulated natural groundwater discharge (depletiondominated supply). However, this could be an artifact of structural error associated with the lumped approach to simulating groundwater discharge. TBHM is not equipped to simulate the timing and magnitude of potential impacts of groundwater withdrawals on discharge from specific spring locations.

TBHM can be improved with additional data and analysis that decrease the uncertainty in the underlying conceptual model. Continued periodic spring discharge measurements will help define temporal variability and the relation to climate variability. Currently, only two wells in the basin are surveyed annually by the Arizona Department of Water Resources, both along the axis of the basin. Additional groundwater-level observations, particularly toward the basin margins, will help determine hydraulic gradients and improve estimates of underflow entering the basin from the western and eastern plateaus. Forecasted drawdowns are 


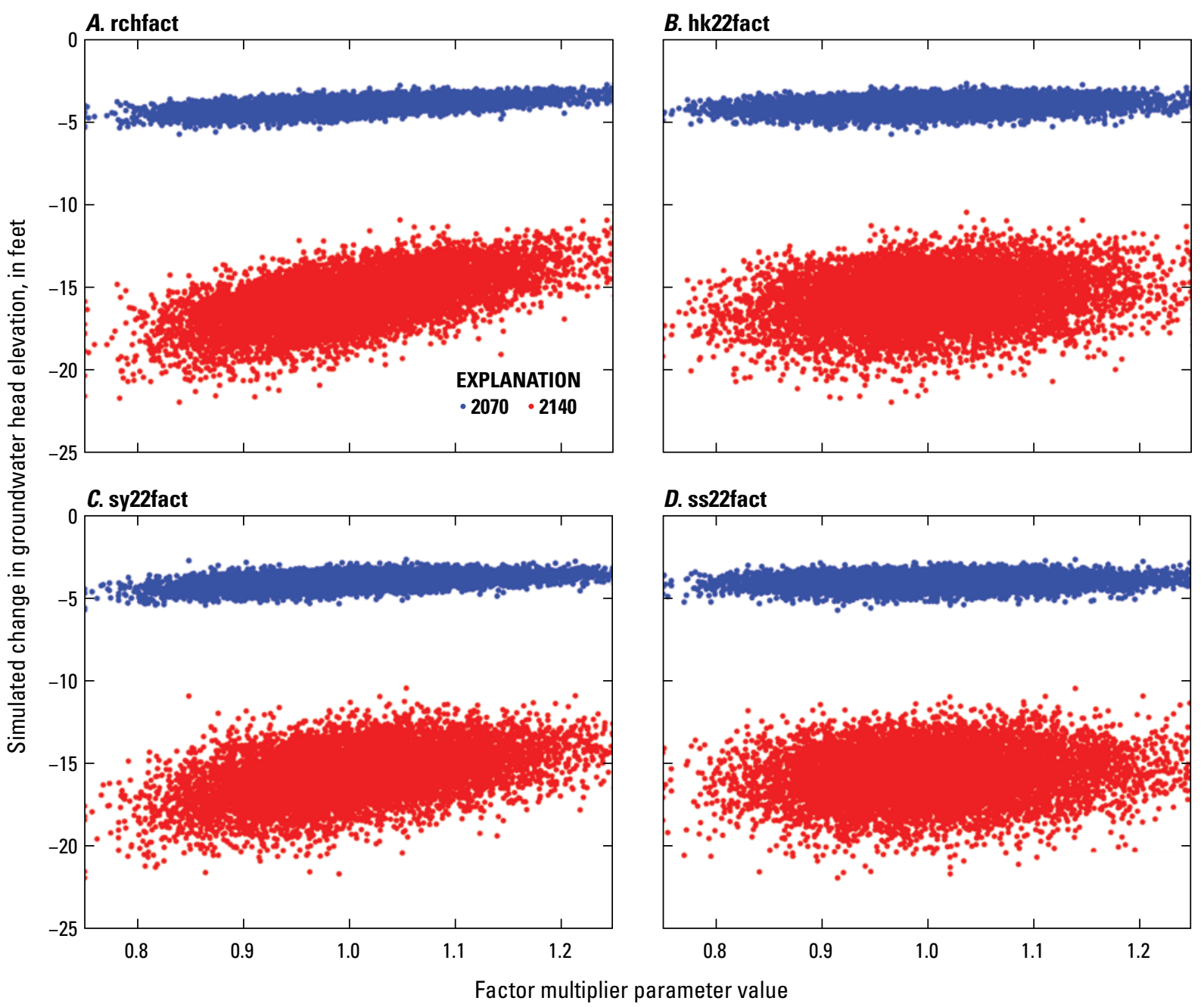

Figure 21. Relation of multiplier parameters to simulated groundwater-level change from 2020 to 2070 (blue dots) and 2020 to 2140 (red dots) at location B using the primary bedrock altitude model and medium pumping scenario.

strongly related to the multiplying factor used to adjust specific yield parameter values in the Truxton basin (fig. 21). Aquifer tests in Truxton basin could reduce the uncertainty of forecasted drawdowns by limiting the range of storage properties deemed to be reasonable.

\section{Summary}

The Truxton Basin Hydrologic Model (TBHM) is a transient model built to forecast potential groundwater-level changes in Truxton basin associated with three different projected pumping scenarios. Withdrawals from the existing Truxton well field increase at different rates in each scenario based on low, medium, and high projections of population growth and water needs. The future pumping scenarios are each simulated with three different interpretations of basin depth supported by the geophysical data collected as part of this investigation (Ball, 2020; Kennedy, 2020). For each of the resulting nine forecast models, a Monte Carlo approach is used to produce a range of possible and probable groundwater-level changes at points throughout the basin given probabilistic ranges of hydrologically reasonable aquifer property values supported by the model calibration results. The ensemble of models that simulate the high future pumping scenario, which increases progressively to 1,840 acre-feet total (including pumping of a proposed new well) per year in 2120 , produce a range of drawdowns between 20 and $39 \mathrm{ft}$ from 2020 to 2140 near the pumping center and a median drawdown of $28 \mathrm{ft}$. The low future pumping scenario, which increases progressively to 650 acre-feet per year in 2120, produces a range of drawdowns between 5 and $15 \mathrm{ft}$ and a median drawdown of $10 \mathrm{ft}$ near the pumping center from 2020 to 2140 . The simulated pumping scenarios assume no other withdrawals occur in the Truxton aquifer during the time of the simulations. TBHM is not intended to simulate current or future discharge from specific spring locations that could be impacted by potential future withdrawals or changes in climate. Forecasted groundwater levels are strongly correlated with simulated future recharge. Repeated inventory of major spring discharges will help reduce uncertainty of estimated recharge rates. 


\section{References Cited}

Anderson, M.P., Woessner, W.W., and Hunt, R.J., 2015, Applied groundwater modeling ( $2 \mathrm{~d}$ ed.): Amsterdam, Elsevier, $564 \mathrm{p}$.

Arizona Bureau of Geology and Mineral Technology, 1981, Geologic map of Santa Fe Railroad Company mineral holdings in northwestern Arizona: Arizona Bureau of Geology and Mineral Technology Miscellaneous Map MM-88A.

Arizona Department of Water Resources, 2018a, Groundwater site inventory (GWSI) database: Arizona Department of Water Resources, accessed November 16, 2018, at https://gisweb2.azwater.gov/gwsi.

Arizona Department of Water Resources, 2018b, Wells 55 database: Arizona Department of Water Resources, accessed November 16, 2018, at https://gisweb2.azwater.gov/gwsi.

Bakker, M., Post, V., Langevin, C.D., Hughes, J.D., White, J.T., Starn, J.J., and Fienen, M.N., 2016, Scripting MODFLOW model development using Python and FloPy: Groundwater, v. 54, no. 5, p. 733-739, accessed October 2018 at https://doi.org/10.1111/gwat.12413.

Ball, L.B., 2020, Major hydrostratigraphic contacts of the Truxton basin and Hualapai Plateau, northwestern Arizona, developed from airborne electromagnetic data, chap. D of Mason, J.P., ed., Geophysical surveys, hydrogeologic characterization, and groundwater flow model for the Truxton basin and Hualapai Plateau, northwestern Arizona: U.S. Geological Survey Scientific Investigations Report 2020-5017, 24 p., https://doi.org/10.3133/sir20205017D.

Barlow, P.M., and Leake, S.A., 2012, Streamflow depletion by wells-Understanding and managing the effects of groundwater pumping on streamflow: U.S. Geological Survey Circular 1376, $84 \mathrm{p}$.

Beard, L.S., and Lucchitta, I., 1993, Geologic map of the Valentine Southeast quadrangle, Mohave County, Arizona: U.S. Geological Survey Geologic Quadrangle Map 1711, scale 1:24,000, accessed January 17, 2020, at https://ngmdb. usgs.gov/Prodesc/proddesc_1216.htm.

Billingsley, G.H., Block, D.L., and Dyer, H.C., 2006, Geologic map of the Peach Springs $30^{\prime} \times 60^{\prime}$ quadrangle, Mohave and Coconino Counties, northwestern Arizona: U.S. Geological Survey Scientific Investigations Map 2900, scale 1:100,000, accessed January 17, 2020, at https://pubs.usgs.gov/ $\operatorname{sim} / 2006 / 2900 /$.
Bills, D.J., and Macy, J.P., 2016, Hydrogeologic framework and characterization of the Truxton aquifer on the Hualapai Reservation, Mohave County, Arizona (ver. 2.0, December 2017): U.S. Geological Survey Scientific Investigations Report 2016-5171, 50 p., accessed March 2018 at https://doi. org/10.3133/sir20165171.

D’Agnese, F.A., O’Brien, G.M., Faunt, C.C., and San Juan, C.A., 1998, Simulated effects of climate change on the Death Valley regional ground-water flow system, Nevada and California: U.S. Geological Survey Water-Resources Investigations Report 98-4041, 40 p.

Doherty, J.E., Fienen, M.N., and Hunt, R.J., 2010, Approaches to highly parameterized inversion-Pilot-point theory, guidelines, and research directions: U.S. Geological Survey Scientific Investigations Report 2010-5168, 36 p.

Elston, D.P., and Young, R.A., 1991, Cretaceous-Eocene (Laramide) landscape development and Oligocene-Pliocene drainage reorganization of transition zone and Colorado Plateau, Arizona: Journal of Geophysical Research, v. 96, no. B7, p. 12389-12406, accessed November 2019 at https://doi.org/10.1029/90JB01978.

Freeze, R.A., and Cherry, J.A., 1979, Groundwater: Englewood Cliffs, N.J., Prentice-Hall, 604 p.

Harbaugh, A.W., 2005, MODFLOW-2005, the U.S. Geological Survey modular ground-water model-The ground-water flow process: U.S. Geological Survey Techniques and Methods 6-A16, variously paginated.

Hill, M.C., and Tiedeman, C.R., 2007, Effective groundwater model calibration; with analysis of data, sensitivities, predictions, and uncertainty: Hoboken, N.J., Wiley and Sons, $455 \mathrm{p}$.

Huntoon, P.W., 1977, Water resources series no. 66-Relationship of tectonic structure to aquifer mechanics in the western Grand Canyon district, Arizona-Completion report, Project B-31-WYO (14-34-0001-6134) to Office of Water Research and Technology, U.S. Department of the Interior: Laramie, University of Wyoming, Water Resources Institute, Water Resources Series no. 66, 51 p., 2 sheets, scale 1:125,000.

Kennedy, J.R., 2020, Gravity surveys and depth to bedrock in the Truxton basin, northwestern Arizona, chap. C of Mason, J.P., ed., Geophysical surveys, hydrogeologic characterization, and groundwater flow model for the Truxton basin and Hualapai Plateau, northwestern Arizona: U.S. Geological Survey Scientific Investigations Report 2020-5017, 10 p., https://doi.org/10.3133/sir20205017C. 
Mason, J.P., Bills, D.J., and Macy, J.P., 2020a, Geology and hydrology of the Truxton basin and Hualapai Plateau, northwestern Arizona, chap. B of Mason, J.P., ed., Geophysical surveys, hydrogeologic characterization, and groundwater flow model for the Truxton basin and Hualapai Plateau, northwestern Arizona: U.S. Geological Survey Scientific Investigations Report 2020-5017, 9 p., https://doi.org/10.3133/sir20205017B.

Mason, J.P., Knight, J.E., Ball, L.B., Kennedy, J.R., Bills, D.J., and Macy, J.P., 2020b, Groundwater availability in the Truxton basin, northwestern Arizona, chap. A of Mason, J.P., ed., Geophysical surveys, hydrogeologic characterization, and groundwater flow model for the Truxton basin and Hualapai Plateau, northwestern Arizona: U.S. Geological Survey Scientific Investigations Report 2020-5017, 14 p., https://doi. org/10.3133/sir20205017A.

Maxey, G.B, and Eakin, T.E., 1949, Groundwater in the White River Valley, White Pine, Nye, and Lincoln Counties, Nevada: State of Nevada, Office of the State Engineer, Water Resources Bulletin no. 8, 59 p., 2 plates.

Natural Resources Consulting Engineers, 2011, Evaluation of the Peach Springs groundwater supply on the Hualapai Reservation: Prepared for the Hualapai Tribe Council by Natural Resources Consulting Engineers, Inc, 102 p.

Niswonger, R.G., Panday, S., and Ibaraki, M., 2011, MODFLOWNWT, A Newton formulation for MODFLOW-2005: U.S. Geological Survey Techniques and Methods 6-A37, 44 p.

Richard, S.M., Reynolds, S.J., Spencer, J.E., and Pearthree, P.A., 2000, Geologic map of Arizona: Arizona Geological Survey, scale 1:100,000, accessed January 17, 2020, at http://repository. azgs.az.gov/uri_gin/azgs/dlio/1705.
Twenter, F.R., 1962, Geology and promising areas for groundwater development in the Hualapai Indian Reservation, Arizona: U.S. Geological Survey Water Supply Paper 1576-A, 38 p., 1 plate.

U.S. Geological Survey, 2018, USGS water data for the Nation: U.S. Geological Survey National Water Information System database, accessed November 16, 2018 at http:// waterdata.usgs.gov/nwis/.

U.S. Geological Survey, 2019a, National hydrography dataset: U.S. Geological Survey National Hydrography Dataset, accessed June 2019 at https://www.usgs.gov/core-sciencesystems/ngp/national-hydrography/national-hydrographydataset.

U.S. Geological Survey, 2019b, USGS Yeti Supercomputer: U.S. Geological Survey Advanced Research Computing web page, accessed December 2019 at https://doi. org/10.5066/F7D798MJ.

White, J.T., Fienen, M.N., and Doherty, J.E., 2016, A python framework for environmental model uncertainty analysis: Environmental Modeling \& Software, v. 85, p. 217-228.

White, J.T., Welter, D.E., and Doherty, J.E., 2019, PEST++ (ver. 4.2.5): U.S. Geological Survey GitHub web page, accessed April 2019 at https://github.com/usgs/pestpp.

Young, R.A., and Hartman, J.H., 2014, Paleogene rim gravel of Arizona-Age and significance of the Music Mountain Formation: Geosphere, v. 10, no. 5, p. 870-891, accessed November 2019 at https://doi.org/doi:10.1130/ GES00971.1. 


\section{Appendixes}




\section{Appendix 1}

Table 1.1. Location of wells and groundwater-level observations in the Truxton Basin Hydrologic Model. See figure 7 for map ID locations. Data obtained from U.S. Geological Survey (2018) and Arizona Department of Water Resources (ADWR) (2018a,b). Site altitudes from ADWR Wells 55 database are approximate.

[ADWR, Arizona Department of Water Resources; GWSI, Groundwater Site Inventory; ID, identification; NWIS, National Water Information System; USGS, U.S. Geological Survey]

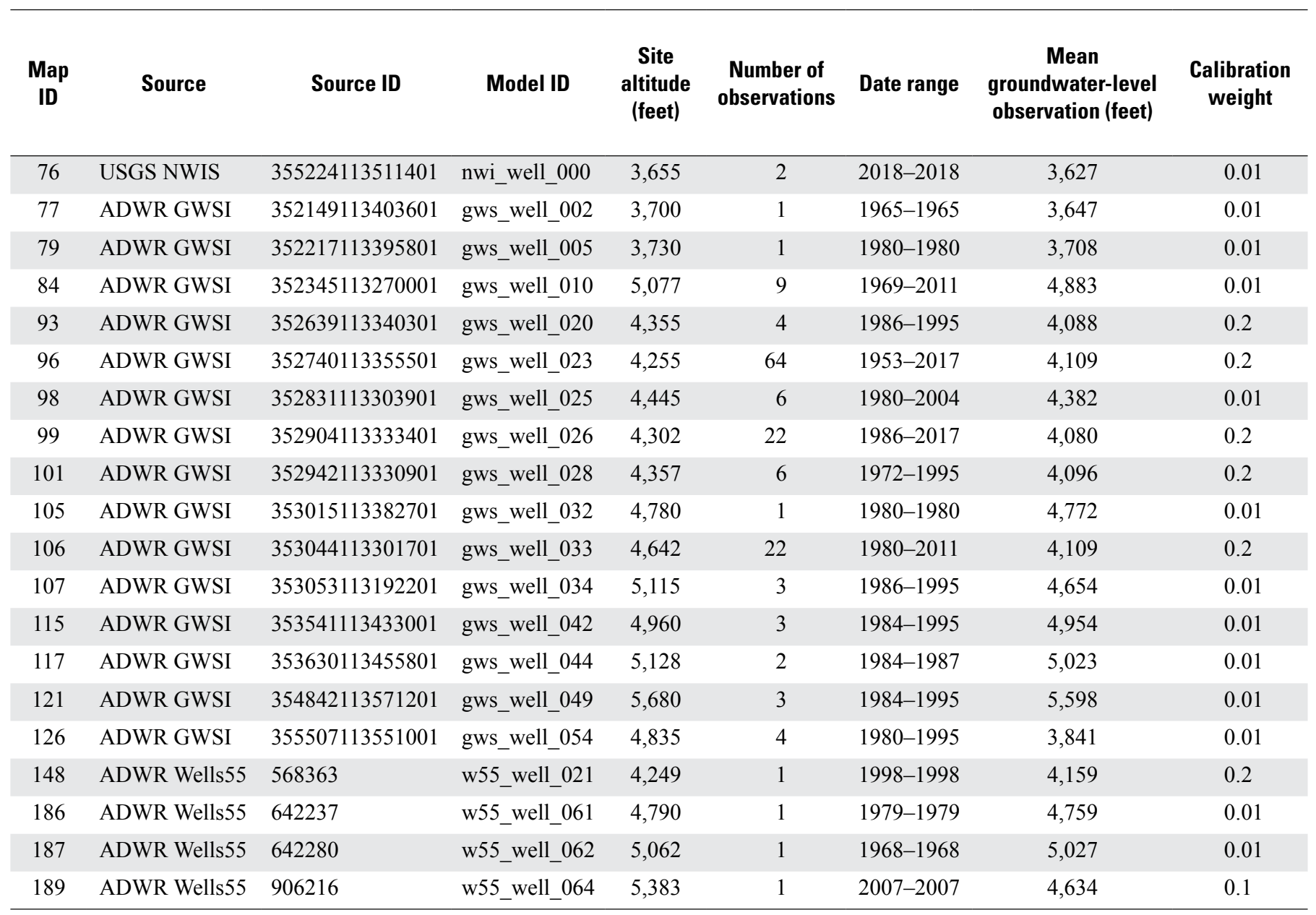


Table 1.2. Location and elevation of spring sites in the Truxton Basin Hydrologic Model. See figure 6 for map ID locations.

[USGS, U.S. Geological Survey; NWIS, National Water Information System; ID, indentification; ft, feet]

\begin{tabular}{|c|c|c|c|c|c|}
\hline Map ID & Data source & Source ID & Model ID & Site elevation (ft) & Calibration weight \\
\hline 4 & Huntoon (1977) & None (spring 12) & pwh_spng_003 & 1,601 & 0.1 \\
\hline 7 & Huntoon (1977) & None (spring 84) & pwh_spng_006 & 4,121 & 0.01 \\
\hline 10 & Huntoon (1977) & Hells Canyon (spring 86) & pwh_spng_009 & 5,351 & 0.01 \\
\hline 12 & Huntoon (1977) & None (spring 48) & pwh_spng_011 & 2,241 & 0.01 \\
\hline 15 & Huntoon (1977) & None (spring 51) & pwh_spng_015 & 2,700 & 0.01 \\
\hline 16 & Huntoon (1977) & Travertine (spring 52) & pwh_spng_016 & 2,159 & 0.01 \\
\hline 17 & Huntoon (1977) & None (spring 33) & pwh_spng_018 & 3,560 & 0.01 \\
\hline 27 & USGS NWIS & 352159113371301 & nwi_spng_000 & 4,710 & 0.01 \\
\hline 41 & USGS NWIS & 353445113255000 & nwi_spng_015 & 4,210 & 0.01 \\
\hline 42 & USGS NWIS & 353643113241000 & nwi_spng_016 & 3,670 & 0.01 \\
\hline 44 & USGS NWIS & 353713113421800 & nwi_spng_018 & 4,710 & 0.01 \\
\hline 45 & USGS NWIS & 353848113225700 & nwi_spng_020 & 4,100 & 0.01 \\
\hline 47 & USGS NWIS & 353921113390200 & nwi_spng_022 & 3,900 & 0.1 \\
\hline 48 & USGS NWIS & 354151113173601 & nwi_spng_023 & 3,360 & 0.01 \\
\hline 49 & USGS NWIS & 354228113374300 & nwi_spng_024 & 2,660 & 0.01 \\
\hline 51 & USGS NWIS & 354346113520200 & nwi_spng_026 & 4,390 & 0.01 \\
\hline 52 & USGS NWIS & 354406113263400 & nwi_spng_028 & 2,350 & 0.01 \\
\hline 53 & USGS NWIS & 354550113313400 & nwi_spng_029 & 1,700 & 0.01 \\
\hline 54 & USGS NWIS & 354659113390000 & nwi_spng_030 & 1,830 & 0.01 \\
\hline 55 & USGS NWIS & 354711113403200 & nwi_spng_031 & 2,650 & 0.01 \\
\hline 57 & USGS NWIS & 354942113581500 & nwi_spng_033 & 5,260 & 0.01 \\
\hline 58 & USGS NWIS & 355111113462300 & nwi_spng_034 & 2,740 & 0.01 \\
\hline 59 & USGS NWIS & 355124113404000 & nwi_spng_035 & 1,390 & 0.01 \\
\hline 60 & USGS NWIS & 355732113455501 & nwi_spng_036 & 1,580 & 0.01 \\
\hline 63 & USGS NWIS & 360312113523400 & nwi_spng_039 & 1,355 & 0.01 \\
\hline 64 & USGS NWIS & 360535113552101 & nwi_spng_041 & 1,209 & 0.01 \\
\hline 65 & USGS NWIS & 352711113391101 & nw2_spng_000 & 4,267 & 0.01 \\
\hline 66 & USGS NWIS & 352624113385201 & nw2_spng_001 & 4,129 & 0.1 \\
\hline 67 & USGS NWIS & 352554113385101 & nw2_spng_002 & 4,053 & 0.1 \\
\hline 68 & USGS NWIS & 354013113414301 & nw2_spng_003 & 4,521 & 0.01 \\
\hline 69 & USGS NWIS & 354547113565701 & nw2_spng_004 & 5,367 & 0 \\
\hline 70 & USGS NWIS & 353300113370801 & nw2_spng_005 & 5,188 & 0.01 \\
\hline 71 & USGS NWIS & 352033113292601 & nw2_spng_006 & 5,378 & 0.01 \\
\hline 72 & USGS NWIS & 353541113261700 & nw2_spng_007 & 3,910 & 0 \\
\hline 73 & USGS NWIS & 354417113353901 & nw2_spng_008 & 4,697 & 0 \\
\hline 74 & USGS NWIS & 353542113261901 & nw2_spng_009 & 3,910 & 0 \\
\hline 75 & USGS NWIS & 354014113251601 & nw2_spng_012 & 2,999 & 0.01 \\
\hline
\end{tabular}




\section{References Cited}

Arizona Department of Water Resources, 2018a, Groundwater site inventory (GWSI) database: Arizona Department of Water Resources, accessed November 16, 2018, at https:// gisweb2.azwater.gov/gwsi.

Arizona Department of Water Resources, 2018b, Wells 55 database: Arizona Department of Water Resources, accessed November 16, 2018, at https://gisweb2.azwater.gov/gwsi.
Huntoon, P.W., 1977, Water resources series no. 66 - Relationship of tectonic structure to aquifer mechanics in the western Grand Canyon district, Arizona - Completion report, Project B-31WYO (14-34-0001-6134) to Office of Water Research and Technology, U.S. Department of the Interior: Laramie, University of Wyoming, Water Resources Institute, Water Resources Series no. 66,51 p., 2 sheets, scale 1:125,000.

U.S. Geological Survey, 2018, USGS water data for the Nation: U.S. Geological Survey National Water Information System database, accessed November 16, 2018, at http://waterdata.usgs.gov/nwis/. 


\section{Appendix 2}

Table 2.1. Summary of forecasted groundwater-level changes from Monte Carlo simulations, 2020-2070, in feet. Locations indicated in figure $17 A$.

\begin{tabular}{|c|c|c|c|c|c|c|c|c|c|}
\hline \multirow{2}{*}{ Location } & \multirow{2}{*}{ Pumping scenario } & \multirow{2}{*}{ Bedrock altitude } & \multirow{2}{*}{$\begin{array}{l}\text { Minimum } \\
\text { change }\end{array}$} & \multicolumn{5}{|c|}{ Percentile } & \multirow{2}{*}{$\begin{array}{c}\text { Maximum } \\
\text { change }\end{array}$} \\
\hline & & & & 1 & 25 & 50 & 75 & 99 & \\
\hline A & High & High & -2.6 & -2.9 & -3.6 & -3.9 & -4.2 & -5.0 & -5.8 \\
\hline A & High & Low & -2.4 & -2.7 & -3.2 & -3.5 & -3.8 & -4.5 & -5.1 \\
\hline A & High & Primary & -2.5 & -2.9 & -3.5 & -3.8 & -4.0 & -4.8 & -5.4 \\
\hline A & Low & High & -2.0 & -2.2 & -2.7 & -2.9 & -3.1 & -3.6 & -4.1 \\
\hline A & Low & Low & -1.8 & -2.0 & -2.4 & -2.6 & -2.8 & -3.2 & -3.7 \\
\hline A & Low & Primary & -1.9 & -2.2 & -2.6 & -2.8 & -3.0 & -3.5 & -3.9 \\
\hline A & Medium & High & -2.2 & -2.5 & -3.0 & -3.3 & -3.5 & -4.2 & -4.8 \\
\hline A & Medium & Low & -2.0 & -2.3 & -2.8 & -3.0 & -3.2 & -3.7 & -4.2 \\
\hline A & Medium & Primary & -2.2 & -2.5 & -2.9 & -3.2 & -3.4 & -4.0 & -4.5 \\
\hline B & High & High & -4.5 & -5.0 & -5.8 & -6.2 & -6.6 & -7.5 & -8.4 \\
\hline B & High & Low & -3.7 & -4.3 & -5.0 & -5.3 & -5.6 & -6.5 & -7.3 \\
\hline B & High & Primary & -4.3 & -5.0 & -5.8 & -6.1 & -6.5 & -7.5 & -8.5 \\
\hline B & Low & High & -1.5 & -1.9 & -2.4 & -2.6 & -2.8 & -3.4 & -4.2 \\
\hline B & Low & Low & -1.2 & -1.6 & -2.1 & -2.3 & -2.5 & -3.0 & -3.8 \\
\hline B & Low & Primary & -1.4 & -1.8 & -2.3 & -2.5 & -2.7 & -3.3 & -4.1 \\
\hline B & Medium & High & -2.8 & -3.2 & -3.8 & -4.0 & -4.3 & -5.0 & -5.8 \\
\hline B & Medium & Low & -2.3 & -2.7 & -3.3 & -3.5 & -3.7 & -4.4 & -5.1 \\
\hline B & Medium & Primary & -2.6 & -3.1 & -3.7 & -4.0 & -4.2 & -4.9 & -5.7 \\
\hline $\mathrm{C}$ & High & High & -1.2 & -1.8 & -2.6 & -2.9 & -3.3 & -4.1 & -5.4 \\
\hline $\mathrm{C}$ & High & Low & -1.2 & -1.8 & -2.5 & -2.8 & -3.2 & -4.0 & -5.1 \\
\hline $\mathrm{C}$ & High & Primary & -1.0 & -1.7 & -2.5 & -2.8 & -3.1 & -4.0 & -5.3 \\
\hline $\mathrm{C}$ & Low & High & -0.4 & -0.8 & -1.5 & -1.8 & -2.1 & -2.8 & -3.7 \\
\hline $\mathrm{C}$ & Low & Low & -0.2 & -0.8 & -1.5 & -1.7 & -2.0 & -2.6 & -3.4 \\
\hline $\mathrm{C}$ & Low & Primary & 0.0 & -0.8 & -1.4 & -1.7 & -2.0 & -2.7 & -3.6 \\
\hline $\mathrm{C}$ & Medium & High & -0.7 & -1.2 & -1.9 & -2.2 & -2.6 & -3.3 & -4.4 \\
\hline $\mathrm{C}$ & Medium & Low & -0.6 & -1.3 & -1.9 & -2.2 & -2.5 & -3.2 & -4.1 \\
\hline $\mathrm{C}$ & Medium & Primary & -0.4 & -1.1 & -1.9 & -2.2 & -2.5 & -3.3 & -4.3 \\
\hline D & High & High & -3.4 & -3.8 & -4.4 & -4.7 & -5.0 & -5.9 & -7.1 \\
\hline D & High & Low & -3.0 & -3.4 & -3.9 & -4.2 & -4.5 & -5.3 & -6.3 \\
\hline D & High & Primary & -3.3 & -3.7 & -4.3 & -4.6 & -4.9 & -5.7 & -6.9 \\
\hline D & Low & High & -1.5 & -1.8 & -2.3 & -2.5 & -2.7 & -3.2 & -4.1 \\
\hline D & Low & Low & -1.2 & -1.6 & -2.0 & -2.2 & -2.4 & -3.0 & -3.7 \\
\hline D & Low & Primary & -1.4 & -1.8 & -2.2 & -2.4 & -2.6 & -3.2 & -4.0 \\
\hline D & Medium & High & -2.3 & -2.6 & -3.1 & -3.4 & -3.6 & -4.3 & -5.3 \\
\hline D & Medium & Low & -1.9 & -2.3 & -2.8 & -3.0 & -3.3 & -3.9 & -4.7 \\
\hline D & Medium & Primary & -2.2 & -2.6 & -3.1 & -3.3 & -3.5 & -4.2 & -5.2 \\
\hline E & High & High & -3.4 & -3.9 & -4.6 & -4.9 & -5.2 & -6.1 & -7.5 \\
\hline E & High & Low & -2.9 & -3.5 & -4.2 & -4.4 & -4.7 & -5.6 & -6.7 \\
\hline E & High & Primary & -3.1 & -3.8 & -4.5 & -4.8 & -5.1 & -6.0 & -7.4 \\
\hline E & Low & High & -1.2 & -1.7 & -2.2 & -2.5 & -2.7 & -3.3 & -4.2 \\
\hline E & Low & Low & -1.0 & -1.5 & -2.0 & -2.2 & -2.4 & -3.0 & -3.8 \\
\hline E & Low & Primary & -1.1 & -1.6 & -2.1 & -2.4 & -2.6 & -3.3 & -4.1 \\
\hline E & Medium & High & -2.1 & -2.6 & -3.2 & -3.4 & -3.7 & -4.5 & -5.5 \\
\hline E & Medium & Low & -1.8 & -2.3 & -2.9 & -3.1 & -3.4 & -4.1 & -5.0 \\
\hline $\mathrm{E}$ & Medium & Primary & -2.0 & -2.5 & -3.1 & -3.3 & -3.6 & -4.4 & -5.4 \\
\hline
\end{tabular}


Table 2.2. Summary of forecasted groundwater-level changes from Monte Carlo simulations, 2020-2140, in feet. Locations indicated in figure $17 \mathrm{~A}$.

\begin{tabular}{|c|c|c|c|c|c|c|c|c|c|}
\hline \multirow{2}{*}{ Location } & \multirow{2}{*}{$\begin{array}{l}\text { Pumping } \\
\text { scenario }\end{array}$} & \multirow{2}{*}{$\begin{array}{l}\text { Bedrock } \\
\text { altitude }\end{array}$} & \multirow{2}{*}{$\begin{array}{l}\text { Minimum } \\
\text { change }\end{array}$} & \multicolumn{5}{|c|}{ Percentile } & \multirow{2}{*}{$\begin{array}{c}\text { Maximum } \\
\text { change }\end{array}$} \\
\hline & & & & 1 & 25 & 50 & 75 & 99 & \\
\hline A & High & High & -10.9 & -12.3 & -14.7 & -15.8 & -17.0 & -20.4 & -24.6 \\
\hline A & High & Low & -9.5 & -11.1 & -13.2 & -14.2 & -15.2 & -18.1 & -21.0 \\
\hline A & High & Primary & -10.3 & -12.1 & -14.4 & -15.4 & -16.6 & -19.7 & -22.8 \\
\hline A & Low & High & -6.2 & -6.9 & -8.1 & -8.7 & -9.3 & -10.9 & -13.0 \\
\hline A & Low & Low & -5.4 & -6.2 & -7.3 & -7.8 & -8.4 & -9.9 & -11.4 \\
\hline A & Low & Primary & -5.9 & -6.7 & -7.8 & -8.4 & -9.0 & -10.6 & -12.1 \\
\hline A & Medium & High & -8.0 & -8.8 & -10.4 & -11.2 & -12.0 & -14.1 & -16.9 \\
\hline A & Medium & Low & -6.9 & -8.0 & -9.3 & -10.0 & -10.7 & -12.6 & -14.5 \\
\hline A & Medium & Primary & -7.4 & -8.6 & -10.1 & -10.8 & -11.6 & -13.6 & -15.5 \\
\hline B & High & High & -20.9 & -23.3 & -26.9 & -28.5 & -30.3 & -34.7 & -38.9 \\
\hline B & High & Low & -17.1 & -20.1 & -23.1 & -24.5 & -25.9 & -29.8 & -33.4 \\
\hline B & High & Primary & -19.9 & -23.0 & -26.6 & -28.2 & -30.0 & -34.6 & -39.1 \\
\hline B & Low & High & -5.8 & -7.3 & -9.0 & -9.9 & -10.7 & -12.9 & -15.3 \\
\hline B & Low & Low & -4.8 & -6.2 & -7.9 & -8.7 & -9.4 & -11.5 & -13.5 \\
\hline B & Low & Primary & -5.5 & -7.0 & -8.9 & -9.7 & -10.5 & -12.7 & -14.9 \\
\hline B & Medium & High & -10.9 & -12.5 & -14.8 & -15.9 & -16.9 & -19.7 & -22.4 \\
\hline B & Medium & Low & -9.0 & -10.9 & -12.8 & -13.8 & -14.7 & -17.2 & -19.5 \\
\hline B & Medium & Primary & -10.4 & -12.4 & -14.6 & -15.6 & -16.7 & -19.5 & -21.9 \\
\hline $\mathrm{C}$ & High & High & -8.5 & -10.3 & -13.0 & -14.3 & -15.6 & -19.2 & -24.2 \\
\hline $\mathrm{C}$ & High & Low & -7.6 & -10.2 & -12.7 & -13.9 & -15.1 & -18.4 & -22.7 \\
\hline $\mathrm{C}$ & High & Primary & -6.8 & -9.8 & -12.5 & -13.8 & -15.1 & -18.7 & -23.4 \\
\hline $\mathrm{C}$ & Low & High & -2.4 & -3.7 & -5.7 & -6.5 & -7.4 & -9.6 & -12.5 \\
\hline $\mathrm{C}$ & Low & Low & -2.2 & -3.6 & -5.5 & -6.3 & -7.1 & -9.1 & -11.6 \\
\hline $\mathrm{C}$ & Low & Primary & -1.8 & -3.4 & -5.5 & -6.4 & -7.2 & -9.5 & -12.1 \\
\hline $\mathrm{C}$ & Medium & High & -4.5 & -6.1 & -8.2 & -9.2 & -10.2 & -12.8 & -16.5 \\
\hline $\mathrm{C}$ & Medium & Low & -4.6 & -6.0 & -8.0 & -8.9 & -9.8 & -12.2 & -15.4 \\
\hline $\mathrm{C}$ & Medium & Primary & -4.1 & -5.8 & -7.9 & -8.9 & -9.9 & -12.5 & -16.0 \\
\hline D & High & High & -15.9 & -17.7 & -20.7 & -22.0 & -23.3 & -27.1 & -32.2 \\
\hline D & High & Low & -13.7 & -15.8 & -18.3 & -19.5 & -20.7 & -24.0 & -28.2 \\
\hline D & High & Primary & -15.1 & -17.2 & -19.9 & -21.2 & -22.5 & -26.1 & -31.0 \\
\hline D & Low & High & -5.2 & -6.3 & -8.0 & -8.8 & -9.6 & -11.7 & -14.4 \\
\hline D & Low & Low & -4.3 & -5.6 & -7.2 & -7.9 & -8.7 & -10.5 & -12.9 \\
\hline D & Low & Primary & -4.9 & -6.2 & -7.9 & -8.6 & -9.4 & -11.4 & -14.0 \\
\hline D & Medium & High & -9.0 & -10.2 & -12.2 & -13.2 & -14.1 & -16.7 & -20.3 \\
\hline D & Medium & Low & -7.7 & -9.1 & -10.9 & -11.7 & -12.6 & -14.9 & -17.9 \\
\hline D & Medium & Primary & -8.6 & -10.0 & -11.9 & -12.8 & -13.7 & -16.2 & -19.6 \\
\hline E & High & High & -16.4 & -18.4 & -21.5 & -22.9 & -24.4 & -28.3 & -33.9 \\
\hline E & High & Low & -13.9 & -16.8 & -19.5 & -20.8 & -22.1 & -25.6 & -29.9 \\
\hline E & High & Primary & -15.0 & -18.0 & -21.1 & -22.4 & -23.9 & -27.8 & -33.0 \\
\hline E & Low & High & -4.7 & -6.0 & -8.1 & -9.0 & -9.9 & -12.2 & -14.9 \\
\hline $\mathrm{E}$ & Low & Low & -4.0 & -5.3 & -7.3 & -8.1 & -8.9 & -11.1 & -13.3 \\
\hline E & Low & Primary & -4.3 & -5.7 & -7.9 & -8.8 & -9.6 & -12.0 & -14.5 \\
\hline E & Medium & High & -8.6 & -10.2 & -12.5 & -13.5 & -14.6 & -17.4 & -21.1 \\
\hline E & Medium & Low & -7.5 & -9.2 & -11.3 & -12.3 & -13.2 & -15.8 & -18.8 \\
\hline E & Medium & Primary & -8.1 & -9.9 & -12.2 & -13.2 & -14.3 & -17.1 & -20.6 \\
\hline
\end{tabular}



Menlo Park Publishing Service Center, California

Manuscript approved for publication March 5, 2020

Edited by Katherine Jacques

Layout by Cory Hurd

Illustration support by JoJo Mangano 


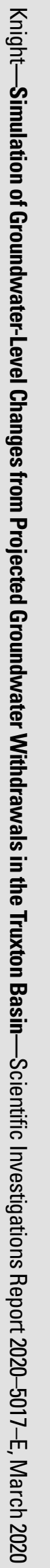

ISSN 2328-0328 (online)

https://doi.org/10.3133/sir20205017E 